\title{
An expert-based reference list of variables for characterizing and monitoring social-ecological systems
}

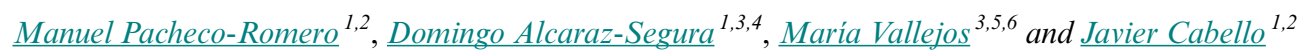

\begin{abstract}
The social-ecological system (SES) approach is fundamental for addressing global change challenges and to developing sustainability science. Over the last two decades, much progress has been made in translating this approach from theory to practice, although the knowledge generated is still sparse and difficult to compare. To better understand how SESs function across time, space, and scales, coordinated, long-term SES research and monitoring strategies under a common analytical framework are needed. For this purpose, the collection of standard datasets is a cornerstone, but we are still far from identifying and agreeing on the common core set of variables that should be used. In this study, based on literature reviews, expert workshops, and researcher perceptions collected through online surveys, we developed a reference list of 60 variables for the characterization and monitoring of SESs. The variables were embedded in a conceptual framework structured in 13 dimensions that were distributed throughout the three main components of the SES: the social system, the ecological system, and the interactions between them. In addition, the variables were prioritized according to relevance and consensus criteria identified in the survey responses. Variable relevance was positively correlated with consensus across respondents. This study brings new perspectives to address existing barriers in operationalizing lists of variables in the study of SESs, such as the applicability for place-based research, the capacity to deal with SES complexity, and the feasibility for long-term monitoring of social-ecological dynamics. This study may constitute a preliminary step to identifying essential variables for SESs. It will contribute toward promoting the systematic collection of data around most meaningful aspects of the SESs and to enhancing comparability across place-based research and long-term monitoring of complex SESs, and therefore, the production of generalizable knowledge.
\end{abstract}

Key Words: coupled human and natural systems; essential social-ecological variables; essential variables; long-term social-ecological research; LTSER; place-based social-ecological research; social-ecological dimensions; social-ecological interactions; social-ecological monitoring; social-ecological system framework; social-ecological system functioning

\section{INTRODUCTION}

The social-ecological system (SES) approach arose to formally recognize that human and natural systems are intertwined and interact across nested spatial and temporal scales (Berkes et al. 2000, Chapin et al. 2009). Currently, the SES approach is widely acknowledged as crucial for addressing global change challenges (Liu et al. 2007, Resilience Alliance 2007, Carpenter et al. 2009) and as a basis for the development of sustainability science (Ostrom 2009, Leslie et al. 2015). It provides new opportunities to understand and manage critical feedbacks between nature and society, which could lead to better ecosystem health, human wellbeing and social equity in the distribution of benefits provided by nature (Collins et al. 2011). However, the complex nature of SESs (Levin et al. 2013) and their heterogeneity across the world challenge place-based social-ecological research (Maass et al. 2016, Norström et al. 2017) and the production of generalizable knowledge from these studies.

Over the past two decades, there has been evident progress in moving the SES approach from theory to practice. First, theoretical studies have defined the general characteristics of SESs, explaining their complexity, dynamics, and emergent properties (e.g., Holling 2001, Berkes et al. 2003, Liu et al. 2007, Chapin et al. 2009). Second, conceptual frameworks were developed to operationalize the SES concept for place-based research (e.g., Scholz and Binder 2004, Redman et al. 2004, Chapin et al. 2006, Ostrom 2009). Such frameworks have provided lists of variables and components/dimensions of the SES, including the assumed structural relations between these building blocks, usually supported by a graphical representation (Meyfroidt et al. 2018). Third, the most recent empirical studies have dealt with place-based research through the development of mapping approaches that characterize the diversity of SESs at different spatial scales (e.g., Václavík et al. 2013, Hamann et al. 2015, Martín-López et al. 2017) or that analyze specific types of SESs at the local scale, e.g., such as fisheries, estuaries, and forest systems (Delgado-Serrano and Ramos 2015, Leslie et al. 2015). Although these empirical studies have provided valuable knowledge on SESs in diverse contexts, it is still difficult to compare and extract general insights from them on how SESs perform over time and across spatial scales (Václavík et al. 2016, Magliocca et al. 2018).

Long-term monitoring provides a fundamental basis for understanding the spatiotemporal dynamics of SESs. This has been made explicit in some global research networks, such as the International Long-Term Ecological Research Network (ILTER) and the Program on Ecosystem Change and Society (PECS;

\footnotetext{
${ }^{1}$ Andalusian Center for the Assessment and Monitoring of Global Change (CAESCG), University of Almería, Almería, Spain, ${ }^{2}$ Department of Biology and Geology, University of Almería, Almería, Spain, ${ }^{3}$ Department of Botany, University of Granada, Granada, Spain, ${ }^{4}$ iecolab, Interuniversity Institute for Earth System Research (IISTA), University of Granada, Granada, Spain, Instituto Nacional de Investigación Agropecuaria (INIA La Estanzuela), Colonia, Uruguay, ${ }^{6}$ Departamento de Métodos Cuantitativos y Sistemas de Información, Facultad de Agronomía, Universidad de Buenos Aires, Buenos Aires, Argentina
} 
Holzer et al. 2018). ILTER includes long-term social-ecological research (LTSER) platforms based on the conceptual model of the SES (Collins et al. 2011). These networks constitute infrastructures for inter- and transdisciplinary research and data collection that aim to produce knowledge for addressing the complex environmental challenges that emerge from naturesociety interactions and to guide sustainability policies (Dick et al. 2018, Mirtl et al. 2018). The main goal of PECS research is the integration of place-based and long-term social-ecological knowledge generated from case studies across the world to better understand social-ecological dynamics (Carpenter et al. 2012, Balvanera et al. 2017, Norström et al. 2017). In addition, the World Network of UNESCO Biosphere Reserves introduced the social-ecological approach into protected area management, as well as the need to monitor changes in the biosphere resulting from human-nature interactions (Holzer et al. 2018). Despite the promising advances in long-term social-ecological monitoring by these networks, one persistent challenge is the harmonization of monitoring protocols to promote cross-site comparability. This would foster more effective interoperability (Vargas et al. 2017) and knowledge generalization from locally driven research initiatives to broader contexts (Dick et al. 2018, Magliocca et al. 2018).

The systematic collection of standard datasets is the cornerstone for enhancing our ability to study the spatial patterns of SESs and their trajectories over time (Holzer et al. 2018). These datasets should be based on a common core set of variables that contribute to fostering a more comprehensive and comparable characterization and monitoring of SESs (Ostrom 2009, Frey 2017). Only a few theoretical studies have dealt with the identification of such common lists of key variables. In this sense, Ostrom (2009) set the most important approach by proposing a list of variables, which were organized in a multilevel nested framework, to understand the sustainability of SESs. Subsequent studies have further developed this list to make it more operational for the empirical study of SESs (e.g., McGinnis and Ostrom 2014, Delgado-Serrano and Ramos 2015, Frey 2017). However, the use of Ostrom's variables in place-based social-ecological research is challenged because of some limitations. For instance, some studies on specific SESs at local scales have reported difficulties in understanding and standardizing the variables and collecting the data (e.g., Basurto et al. 2013, Cox 2014, Delgado-Serrano and Ramos 2015, Leslie et al. 2015). Likely because of these constraints, only a few studies have used this approach for the spatially explicit mapping of SESs (Dressel et al. 2018, Rocha et al. 2020). To overcome these barriers to operationalization, a standard list of variables should be useful in dealing with the diversity of social-ecological contexts (McGinnis and Ostrom 2014, Frey 2017), the complex nature of SESs, and the availability of data (Rocha et al. 2020). Finding a set of variables that meets these requirements will enable the collection of datasets worldwide to enhance place-based research on complex SESs as well as the observation and tracking of long-term trends, encouraging cross-system comparisons.

A promising initiative contributing to the development of core lists of variables to make monitoring of the Earth system comparable across sites is the identification of essential variables (EVs). EVs constitute the minimum set of critical measurements for the study, report, and management of a system and its changes (Reyers et al. 2017, Guerra et al. 2019). Major steps have been taken in the fields of biodiversity (Pereira et al. 2013), climate (Bojinski et al. 2014), and oceans (Constable et al. 2016). However, in transdisciplinary fields, only guidelines have been suggested thus far to identify EVs. Reyers et al. (2017) proposed criteria for the selection of EVs that link socioeconomic and environmental concerns for monitoring sustainable development goals. Guerra et al. (2019) defined a framework for identifying EVs that characterize human-nature dynamics in the context of conservation, and Balvanera et al. (2016) developed a pathway for identifying essential ecosystem service variables. Hence, a widespread consensus on a comprehensive list of EVs for SES monitoring is still lacking, although recent studies have provided valuable insights for identifying relevant variables. For instance, Frey (2017) suggested that in addition to SES sustainability, variables could also inform on other outcomes, such as resilience, social equity, or economic efficiency. Holzer et al. (2018) proposed that indicators collected across LTSER platforms might include qualitative social, political, and economic variables, e.g., sense of place, property ownership, or governance structures, to understand trends in quantitative variables, e.g., population density, ecosystem services, or biodiversity. Additionally, within the LTSER context, Dick et al. (2018) highlighted the importance of collecting social and biophysical data for addressing complex challenges that emerge from nature-society interactions, e.g., climate change, biodiversity loss, or environmental hazards. Additional studies that have developed spatially explicit maps of SESs provide multiple examples of relevant variables from which it is feasible to collect data to characterize SES dynamics (e.g., Alessa et al. 2008, Ellis and Ramankutty 2008, Václavík et al. 2013, Castellarini et al. 2014, Hamann et al. 2015, Martín-López et al. 2017, Vallejos et al. 2020).

In summary, it is crucial to advance toward an established list of relevant and feasible variables for characterizing and monitoring SESs that can be used in science, policy, and management. Developing such a list could foster a long-term coordinated socialecological monitoring network, allowing the intercomparability of place-based social-ecological research (Redman et al. 2004, Collins et al. 2011, Carpenter et al. 2012, Balvanera et al. 2017) and strengthening the production of generalizable knowledge on SESs across different regions of the world (Frey 2017). To our knowledge, the few integrative lists of SES variables have been built only from Ostrom's (2009) approach, and difficulties have been sometimes reported for their operationalization in empirical research (Delgado-Serrano and Ramos 2015). To progress in the development of a core set of integrative variables, it is important to provide new insights into the fundamental traits to characterize the functioning of SESs, i.e., how the system performs (Jax 2010). For this purpose, it is necessary to compile the variables used in previous studies and to incorporate the assessments of experts working in inter- and transdisciplinary fields (Redman et al. 2004). In this study, we aimed to develop a reference list of prioritized variables for characterizing and monitoring SESs. We provide evidence about the potential most relevant variables based on a comprehensive literature review, an iterative process driven by expert workshops, and researcher perceptions collected through online surveys. 
Fig. 1. Workflow. The main methodological steps are identified on the left, and their respective results are on the right. The boxes group together the methodological steps to indicate the two main stages of this study: (1) the development of a list of variables structured under a social-ecological system (SES) conceptual framework and (2) the prioritization of the list of variables.

\section{METHODS RESULTS}

Literature review $\longrightarrow$ Candidate variables for characterizing and monitoring SESs, and candidate conceptual frameworks to structure the list of variables.

Workshop $1 \longrightarrow$ Preliminary list of 77 variables structured into 12 dimensions across 3 components: social system ( 2 dimensions), ecological system ( 5 dimensions), and interactions (5 dimensions). The Resilience Alliance conceptual framework was selected to depict the relationships among them.

Preliminary $\longrightarrow 56$ responses. Evaluation of the preliminary list of variables and structuring dimensions: online survey $\longrightarrow$ suggestions for additions, deletions, and general comments.

Workshop $2 \longrightarrow$ Improved list of 149 variables structured into 13 dimensions. "Governance" was incorporated as a new dimension of the social system component.

List of 149 variables structured under a SES conceptual framework ( 3 components, 13 dimensions)

$$
\text { ऽ }
$$

\begin{tabular}{|c|c|}
\hline $\begin{array}{l}\text { Final online } \\
\text { survey }\end{array}$ & $\begin{array}{l}59 \text { responses. Positive linear relationship between perceived relevance (R) of variables and } \\
\text { consensus }(\mathbf{C}) \text { across respondents. Additional suggestions and comments. }\end{array}$ \\
\hline
\end{tabular}

\section{Prioritization of} variables

60 variables were prioritized: 10 -level 1 ( $\mathrm{R}$ and $\mathrm{C}>90^{\text {th }}$ percentile); 16-level 2 ( $\mathrm{R}$ and $\mathrm{C}$ between $75^{\text {th }}$ and $90^{\text {th }}$ percentiles); 22-level 3 ( $\mathrm{R}>75^{\text {th }}$ percentile, $\mathrm{C}$ between $50^{\text {th }}$ and $75^{\text {th }}$ percentiles, and vice-versa); 12-level 4 ( $\mathrm{R}$ and $\mathrm{C}$ between $50^{\text {th }}$ and $75^{\text {th }}$ percentiles).

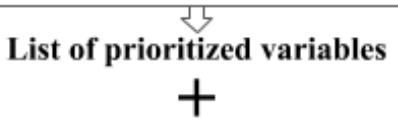

Analysis of respondents' additional comments

Potential biases and gaps in the list of variables

\section{METHODS}

\section{Developing a comprehensive list of social-ecological system variables}

The list of variables for characterizing and monitoring SESs was developed in four steps (Fig. 1). First, we performed a literature review to search for candidate variables. We also identified candidate conceptual frameworks to structure the list of variables and to depict the relationships among them. We searched Scopus for journal articles and book chapters with the following terms in their titles, keywords, or abstracts: "soci*-ecological system*" and ("map"" or "framework"). Then, we followed a "snowballing" approach (see van Oudenhoven et al. 2018) to identify additional papers that explicitly developed SES maps, SES conceptual frameworks, or were pivotal for understanding SES functioning (Appendix 1). From this search, we registered all variables and conceptual frameworks that were empirically used or theoretically introduced to characterize SESs. Second, we organized an initial workshop (November 2015) with experts on Earth system dynamics (carbon, water, energy, nutrient cycling) and sustainability science (ecosystem services, transdisciplinarity, translational ecology; see participants in Appendix 2) to develop a preliminary list of variables structured under an integrative conceptual framework. Experts analyzed the candidate variables and selected the most suitable framework. The variables were classified into a nested scheme of three SES components, and there were multiple dimensions within these components. Third, to complete the list of variables and to validate the structure of the dimensions and components, we conducted a preliminary online survey targeted at researchers with experience in SES science (August-December 2016; see acknowledgments). The survey (Appendix 3) introduced the list of variables classified into the dimensions and components and asked respondents to score each variable from 0 to 5 according to its relevance for characterizing and monitoring SESs. Scientists were also encouraged to suggest the addition or deletion of variables and to provide any other comments. These scores, suggestions, and comments were analyzed during a second scientific workshop (January 2017; see participants in Appendix 2) to improve the set of variables and dimensions. We then launched a final online survey (January-May 2017; Appendix 4) that was distributed to a new group of researchers with similar expertise in SES science (see acknowledgments). As in the preliminary survey, they were asked to score each variable from 0 to 5 and to provide comments and suggestions.

\section{Prioritization of social-ecological variables}

To prioritize the variables from the improved list, we conducted a "relevance vs. consensus" analysis using the scores from the final survey (Fig. 1) on the importance perceived by experts for each variable for characterizing and monitoring SESs. The relevance was evaluated as the mean of the scores assigned by the experts 
to each variable. The consensus was estimated as the difference between the maximum standard deviation of the scores found throughout the 149 variables and the standard deviation of the score for each variable (low differences indicated low consensus and high differences, high consensus). Then, the variables were separately ranked according to their percentile for relevance and consensus and grouped into five categories (four levels of priority and one nonpriority). Priority level 1 (top priority) included variables with relevance and consensus above the $90^{\text {th }}$ percentile; level 2 included variables between the $75^{\text {th }}$ and $90^{\text {th }}$ percentiles; level 3 included variables with relevance above the $75^{\text {th }}$ percentile but consensus between the $50^{\text {th }}$ and $75^{\text {th }}$ percentiles and vice versa; and finally, level 4 included variables with relevance and consensus between the $50^{\text {th }}$ and $75^{\text {th }}$ percentiles. The nonpriority category included variables with relevance and consensus below the $50^{\text {th }}$ percentile. Finally, to assess potential biases and gaps in the list of variables, we analyzed the additional suggestions and comments provided by researchers in both surveys (Fig. 1). This analysis was performed by annotating key words and organizing them through generalization in a conceptual map. We identified recurrent key words (addressed five or more times by respondents) as "featured topics."

\section{RESULTS}

Variables and dimensions to guide the characterization and monitoring of SESs

We developed a list of 149 variables structured in 13 dimensions within the three components of the SESs: the social system, the ecological system, and their interactions (Table A5.1, Appendix 5). We selected the Resilience Alliance conceptual framework (Resilience Alliance 2007) in the first workshop as the most pragmatic and illustrative framework to depict the structural relations among the dimensions and to guide more coordinated SES characterization and monitoring (Fig. 2). In the social system, three dimensions (human population dynamics, wellbeing and development, and governance) containing 36 variables were identified. In the ecological system, five dimensions (organic carbon dynamics, water dynamics, nutrient cycling, surface energy balance, and disturbance regime) containing 51 variables were identified. In the interactions between nature and people, five dimensions (ecosystem service supply, ecosystem disservice supply, ecosystem service demand, human actions on the environment, and social-ecological coupling) containing 62 variables were identified. The featured topics derived from the researchers' comments in the preliminary online survey that guided the development of the list of variables and dimensions are shown in Fig. A6.1, Appendix 6, as well as in the conceptual map in Appendix 7.

\section{Prioritization of social-ecological variables based on scientist scoring}

The analysis of the final survey revealed a significant positive linear relationship $(n=149 ; r=0.82 ; p$-value $<0.001)$ between the average relevance for characterizing and monitoring SESs obtained for each variable and the consensus observed across respondents (Fig. 3). A positive slope lower than one $(\mathrm{m}=0.33$; p-value $<0.001$; root-mean-square error $=0.12$ ) indicated that relevance increased faster than consensus. By applying the prioritization thresholds, 60 variables were considered relevant because they were included at one of the four priority levels (Table
1). Ten variables were included under priority level 1 (highest priority), representing the dimensions of nutrient cycling, disturbance regime (ecological system component), ecosystem service supply, human actions on the environment, and socialecological coupling (interaction component). Sixteen variables were considered at priority level 2, adding new dimensions such as well-being and development, governance (social system), water dynamics (ecological system), and ecosystem service demand (interaction component). Twenty-two variables constituted priority level 3, incorporating the dimensions human population dynamics (social system), organic carbon dynamics, and surface energy balance (ecological system). Finally, level 4 (lowest priority) added 12 variables, two of them belonging to the dimension of ecosystem disservice supply (interaction component). Thus, the prioritized variables represented all 13 dimensions proposed to characterize SES functioning, though we found it remarkable that no variables in the social system component reached priority level 1, reaching level 2 at the highest. Overall, $25 \%$ of the variables assessed for the social system were prioritized, $24 \%$ in the ecological system, and $48 \%$ for the interaction component. To explore in detail the relevance and consensus obtained for each variable, see Figs. A6.2 to A6.14 in Appendix 6 and Appendix 8.

Fig. 2. Conceptual framework to guide the characterization and monitoring of social-ecological systems (SESs). The framework is structured in three components (social system, ecological system, and interactions between them) and 13 dimensions of SES functioning (modified from Resilience Alliance 2007).

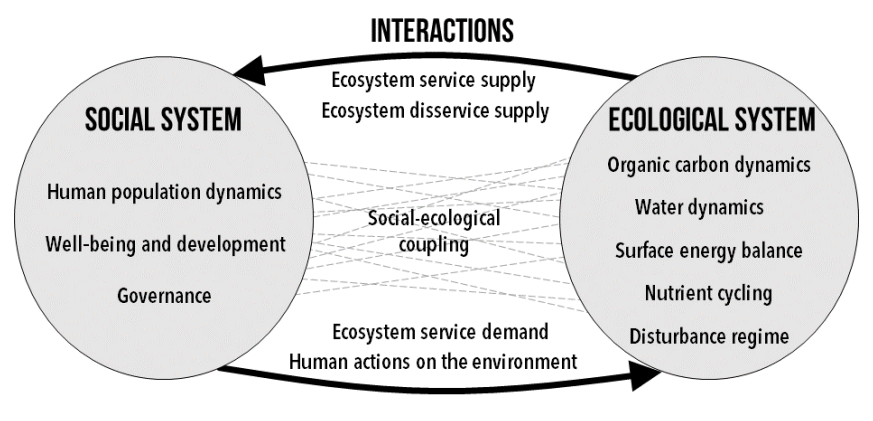

\section{Additional comments from the respondents}

The analysis of respondents' comments and suggestions in the final survey allowed us to identify 14 featured topics indicating potential biases and gaps in the list of variables (Fig. 4 and Appendix 7). In the social system, several researchers emphasized the importance of "social equity" and "living conditions" to characterize the well-being and development dimension. In the ecological system, "biodiversity" was the most featured topic, which was considered the foundation for explaining the supply of provisioning, regulating, and cultural ecosystem services. Respondents also argued that the water dynamics dimension should be mainly based on the characterization of the "water balance," with some additional variables concerning water and soil salinity and seasonality. Within the interactions, the importance of measuring the "strength of links between people and nature" was the most addressed topic. Within this scope, other related featured topics were "resource consumption patterns," the 
Fig. 3. Relevance and consensus obtained by variables for characterizing and monitoring social-ecological systems (SESs) in the final survey. Relevance was evaluated as the mean of the scores assigned by experts to each variable. The consensus was estimated as the difference between the maximum standard deviation of the scores found throughout the 149 variables and the standard deviation of the score for each variable (low differences indicated low consensus and high differences, high consensus). Squares, circles, and plus signs identify the variables belonging to the social system, ecological system, and interaction components, respectively. Horizontal and vertical lines represent the $25^{\text {th }}, 50^{\text {th }}, 75^{\text {th }}$, and $90^{\text {th }}$ percentiles of relevance and consensus. Boxes over the grid illustrate the clustering of the variables by priority levels. The red box (priority level 1) includes those variables with relevance and consensus above the $90^{\text {th }}$ percentile; the green box (level 2) includes those variables with both values between the $75^{\text {th }}$ and $90^{\text {th }}$ percentiles; the yellow box (level 3) includes those with relevance above the $75^{\text {th }}$ percentile but consensus between the $50^{\text {th }}$ and $75^{\text {th }}$ percentiles and vice versa; and the blue box (level 4) includes variables with relevance and consensus between the $50^{\text {th }}$ and $75^{\text {th }}$ percentiles. At the bottom right of the figure, the equation of the regression line, the significance of the line slope ( $p$-value) and the rootmean-square error (RMSE) are indicated, as are the number of variables (n), the Pearson's correlation coefficient (r), and its significance (p-value).

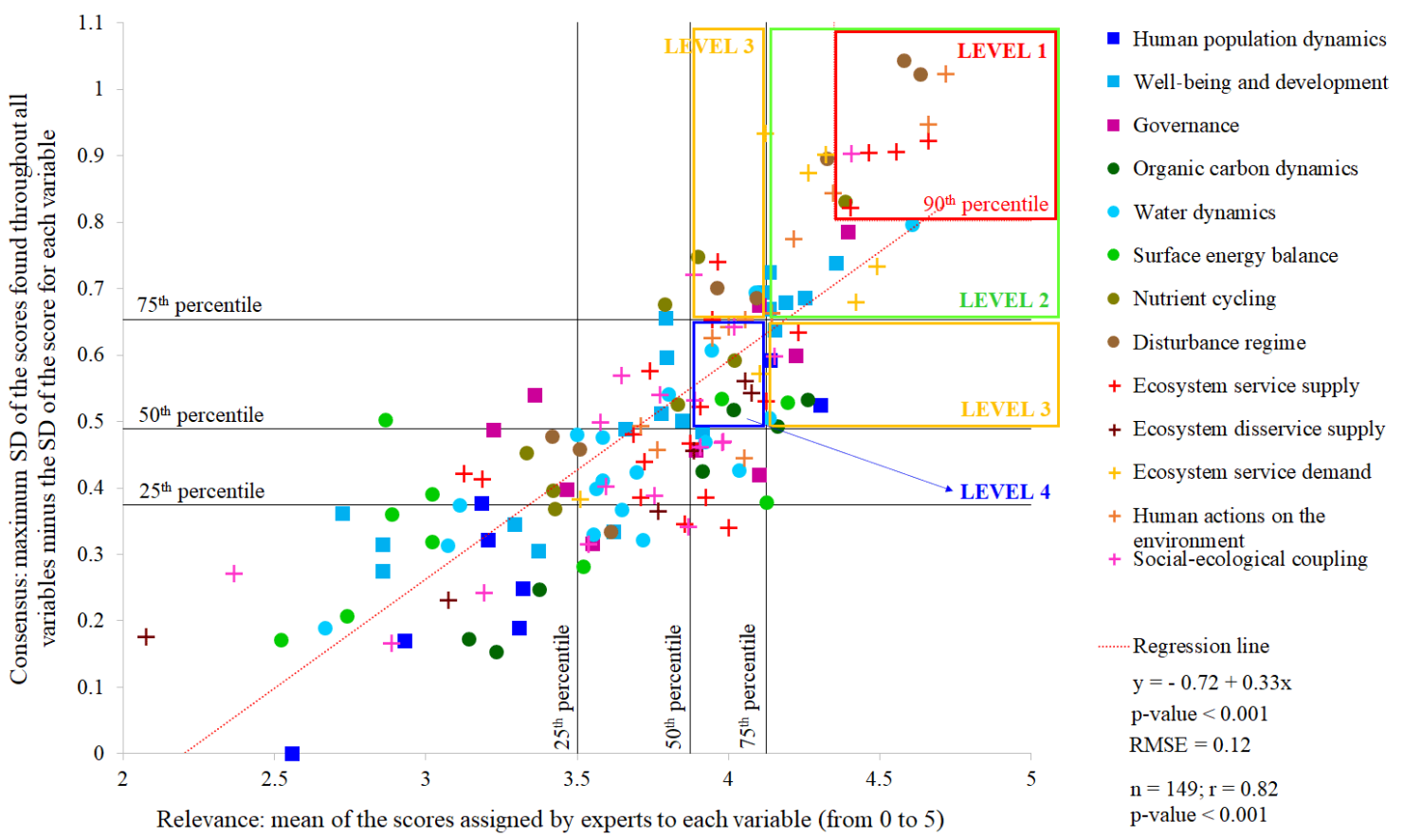

"cultural value of nature," "cultural ecosystem service demand," "local ecological knowledge," and the "beneficial human actions on the environment." Other highlighted issues were transversal to the three SES components. Some researchers argued that all "variables should reflect the underlying processes and functions" occurring in SESs, instead of outcomes or symptoms of their functioning. In addition, the need to consider more variables related to "energy fluxes" as indicators of system complexity was also suggested. Finally, researchers also stated that variable relevance might be "context-dependent" and that SES complexity makes it "difficult to assess some variables." An extended version of Fig. 4 with the whole list of topics is available in Fig. A6.15, Appendix 6.

\section{DISCUSSION}

With this study, we contributed to the identification of a common core set of relevant variables for the study and monitoring of SESs by providing a reference list of 60 variables, which were structured in 13 dimensions of SES functioning embedded in the social, ecological, and interaction components of the SES (Fig. 2). The use of such a nested framework contributes to understanding the relationships among variables, aims to maintain the holistic approach in the study of SESs, and promotes transdisciplinary communication by acting as a boundary object (Ostrom 2009, Meyfroidt et al. 2018, van Oudenhoven et al. 2018). The variables were classified into four levels of priority according to researcher consensus on their relevance (Fig. 3 and Table 1) to facilitate their adaptation to the data availability, context, and sociopolitical needs. The prioritization revealed the crucial role that socialecological interactions have in characterizing SES complexity (Liu et al. 2007, Carpenter et al. 2009) but also showed that all the dimensions of social-ecological functioning are necessary to disentangle SES dynamics (Table 1). In general, the development of reference lists of variables is an emerging need in sustainability research to foster the collection of structured, long-term, coordinated core datasets across SESs (Frey 2017, Holzer et al. 
Table 1. List of prioritized variables for characterizing and monitoring social-ecological systems (SESs). The list is structured into 13 dimensions across the three components of a SES (see Fig. 2). Priority level 1 includes variables with relevance and consensus above the 90th percentile; level 2 includes variables with both values between the 75th and 90th percentile; level 3 contains those variables whose relevance was above the 75th percentile and consensus between the 50th and 75th percentiles and vice versa; and finally, level 4 includes those variables with relevance and consensus between the 50th and 75th percentiles. An extended version of this table including the nonpriority variable category, as well as examples and explanations for the variables, is available in Table A5.2, Appendix 5.

\begin{tabular}{|c|c|c|c|c|c|}
\hline \multirow[t]{2}{*}{ Component } & \multirow[t]{2}{*}{ Dimension } & \multicolumn{4}{|c|}{ Priority variables (decreasing priority from 1 to 4 ) } \\
\hline & & Level 1 & Level 2 & Level 3 & Level 4 \\
\hline \multirow[t]{3}{*}{$\begin{array}{l}\text { Social } \\
\text { system }\end{array}$} & $\begin{array}{l}\text { Human population } \\
\text { dynamics }\end{array}$ & & & $\begin{array}{l}\text { - Population density } \\
\text { - Population distribution }\end{array}$ & \\
\hline & $\begin{array}{l}\text { Well-being and } \\
\text { development }\end{array}$ & & $\begin{array}{l}\text { - Access to drinking water } \\
\text { - Educational level } \\
\text { - Environmental quality } \\
\text { - Poverty } \\
\text { - Social equity }\end{array}$ & $\begin{array}{l}\text { - Water sanitation } \\
\text { - Water scarcity }\end{array}$ & \\
\hline & Governance & & - Current conflicts & $\begin{array}{l}\text { - Corruption level } \\
\text { - Political stability }\end{array}$ & \\
\hline \multirow[t]{5}{*}{$\begin{array}{l}\text { Ecological } \\
\text { system }\end{array}$} & $\begin{array}{l}\text { Organic carbon } \\
\text { dynamics }\end{array}$ & & & $\begin{array}{l}\text { - Net primary productivity } \\
\text { - Organic carbon storage }\end{array}$ & $\begin{array}{l}\text { - Ecosystem composition } \\
\text { by plant functional type }\end{array}$ \\
\hline & Water dynamics & & - Precipitation & $\begin{array}{l}\text { - Actual evapotranspiration } \\
\text { - Actual water deficit (or } \\
\text { excess) }\end{array}$ & $\begin{array}{l}\text { - Soil water infiltration } \\
\text { capacity }\end{array}$ \\
\hline & $\begin{array}{l}\text { Surface energy } \\
\text { balance }\end{array}$ & & & - Net solar radiation & - Land surface temperature \\
\hline & Nutrient cycling & - Nitrogen fixation & & - Soil phosphorus availability & - Nitrogen deposition \\
\hline & Disturbance regime & $\begin{array}{l}\text { - Drought occurrence } \\
\text { - Flood occurrence }\end{array}$ & - Fire occurrence & $\begin{array}{l}\text { - Hurricanes/storms } \\
\text { occurrence } \\
\text { - Pest outbreaks occurrence }\end{array}$ & \\
\hline \multirow[t]{5}{*}{ Interactions } & $\begin{array}{l}\text { Ecosystem service } \\
\text { supply }{ }^{\dagger 1}\end{array}$ & $\begin{array}{l}\text { - Cropland production }(\mathrm{P}) \\
\text { - Livestock production }(\mathrm{P}) \\
\text { - Surface and groundwater } \\
\text { sources for drinking }(\mathrm{P}) \\
\text { - Hydrological cycle and } \\
\text { water flow maintenance } \\
(\mathrm{R})\end{array}$ & & $\begin{array}{l}\text { - Surface and groundwater } \\
\text { sources for nondrinking } \\
\text { purposes }(\mathrm{P}) \\
\text { - Local climate regulation (R) } \\
\text { - Pest and disease control (R) } \\
\text { - Pollination and seed } \\
\text { dispersal (R) }\end{array}$ & $\begin{array}{l}\text { - Chemical conditions } \\
\text { maintenance of } \\
\text { freshwaters and salt } \\
\text { waters }(\mathrm{R})\end{array}$ \\
\hline & $\begin{array}{l}\text { Ecosystem disservice } \\
\text { supply }^{2}\end{array}$ & & & & $\begin{array}{l}\text { - Abiotic-economic (e.g., } \\
\text { droughts, fires) } \\
\text { - Bioeconomic (e.g., } \\
\text { biological invasions) }\end{array}$ \\
\hline & $\begin{array}{l}\text { Ecosystem service } \\
\text { demand }\end{array}$ & & $\begin{array}{l}\text { - Appropriation of land for } \\
\text { agriculture } \\
\text { - Energy use level } \\
\text { - Water use level } \\
\text { - Water use for irrigated crops }\end{array}$ & - Material use level & $\begin{array}{l}\text { - Human appropriation of } \\
\text { net primary production } \\
\text { (HANPP) }\end{array}$ \\
\hline & $\begin{array}{l}\text { Human actions on } \\
\text { the environment }\end{array}$ & $\begin{array}{l}\text { - Land cover/land use } \\
\text { change } \\
\text { - Land use intensity }\end{array}$ & $\begin{array}{l}\text { - Eutrophication of water bodies } \\
\text { - Land protection } \\
\text { - Pollution } \\
\text { - Soil erosion }\end{array}$ & $\begin{array}{l}\text { - Anthropogenic water } \\
\text { management }\end{array}$ & $\begin{array}{l}\text { - Net } \mathrm{CO}_{2} \text { flux } \\
\text { - Territorial connectivity }\end{array}$ \\
\hline & $\begin{array}{l}\text { Social-ecological } \\
\text { coupling }\end{array}$ & $\begin{array}{l}\text { - Local natural capital } \\
\text { dependence }\end{array}$ & & $\begin{array}{l}\text { - Access to natural and } \\
\text { seminatural areas } \\
\text { - Biocapacity }\end{array}$ & $\begin{array}{l}\text { - Import/export rates of } \\
\text { agricultural products } \\
\text { - Renewable energy use }\end{array}$ \\
\hline
\end{tabular}

${ }^{\dagger} \mathrm{P}=$ provisioning services; $\mathrm{R}=$ regulating services

${ }^{1}$ Haines-Young and Potschin (2013), ${ }^{2}$ Shackleton et al. (2016) (see Table A5.2, Appendix 5) 
2018). This will help to enhance our ability to study SESs over time and across space, enabling cross-system comparisons and the standardization of monitoring protocols.

Fig. 4. Featured topics (addressed by five or more respondents in different dimensions) related to potential biases and gaps in the list of variables identified from comments and suggestions in the final survey. Black, white, and gray bars represent the social system, ecological system, and interaction components, respectively, while striped bars reflect issues that are transversal to the whole conceptual framework. (See also these topics in the conceptual map of Appendix 7).

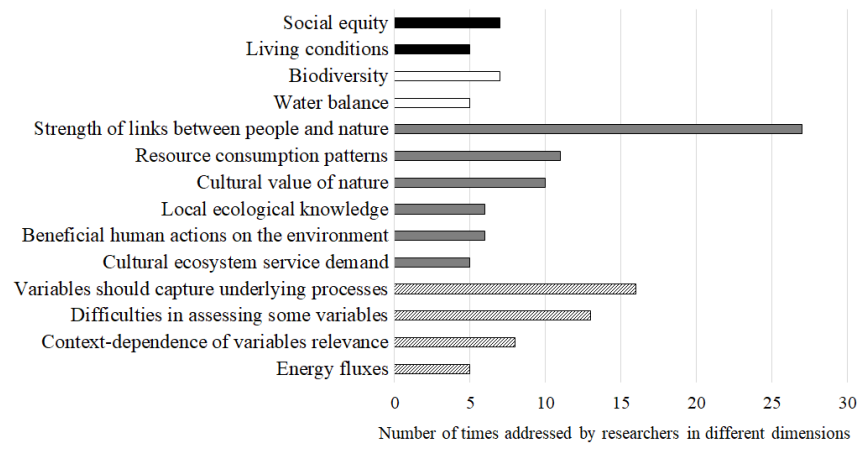

\section{Insights to address existing barriers in SES research}

The list of variables presented in this study offered new perspectives for addressing the main barriers, i.e., applicability to place-based research, representativeness of SES complexity, and feasibility for monitoring, detected in operationalizing existing lists to assess SESs (e.g., Ostrom 2009, McGinnis and Ostrom 2014, Delgado-Serrano and Ramos 2015, Frey 2017). First, regarding their applicability for place-based research, according to van Oudenhoven et al. (2018), variables not only need to be credible, i.e., scientifically sound based on expert judgment, scientific literature, and a conceptual framework, but also practically feasible for collection. For instance, Ostrom's list of variables, which was conceived to diagnose the sustainability of SESs (Ostrom 2009), has sometimes been considered too abstract and general to characterize concrete systems (Cox 2014, DelgadoSerrano and Ramos 2015, Hinkel et al. 2015, Leslie et al. 2015). To overcome such limitations, we emphasized the selection of variables easily derivable from primary data that have been used in previous research for the spatially explicit mapping of SESs (Appendix 1; Table A5.3, Appendix 5). In addition, the list of variables and the conceptual framework must offer certain flexibility to be adapted to the diversity of contexts and scales of analysis and to data availability (McGinnis and Ostrom 2014). The Ostrom SES framework presents a hierarchical structure at different levels (tiers), with variables and subvariables that could be adapted depending on the type of SES (Delgado-Serrano and Ramos 2015) but that lack any guidance on their relevance. In our study, we not only hierarchically structured the variables under the dimensions and components of SESs but also distributed them into priority levels according to their agreed relevance for characterizing SESs. By doing so, we provide guidance for adapting variable selection according to the research context while retaining consistency regarding the relevance and representativeness of variables across SES dimensions.

Second, regarding their representativeness of SES complexity, variables not only need to provide information on the different "pieces" of the system but also must help to understand the linkages among such "pieces"(Ostrom 2009). To achieve this goal, embedding variables within a nested conceptual framework helps to organize them across components and hierarchical levels while depicting the structural relationships between them (Frey 2017, Ostrom 2009, McGinnis and Ostrom 2014). For instance, Ostrom's SES framework uses an anthropocentric perspective of SESs, where variables that are supposed to focus on the ecological subsystem also have a social origin or reflect the interaction between humans and nature (Binder et al. 2013). However, if most variables make sense only if humans exist, it implies that there exists an unbalanced representation among the social, ecological, and interaction variables, which is acknowledged as a key principle for addressing SES complexity (Liu et al. 2007, Resilience Alliance 2007, Reyers et al. 2017). Our proposal provides a scheme that categorizes all variables into 13 expertvalidated dimensions embedded into the three key components of a SES, i.e., social system, ecological system, and interactions. The variables for characterizing the ecological system followed an "ecocentric" perspective (sensu Binder et al. 2013) and were structured into five dimensions, where the system and its processes were analyzed independently of their links to humans. For the social system, our variables focused on understanding human population dynamics, well-being and development, and governance dimensions without considering ecological processes. Finally, for the interactions between humans and nature, similar to Ostrom (2009), our variables addressed the reciprocity between the social and ecological systems (Binder et al. 2013). However, we suggested a more detailed structure for the variables, which we divided into five dimensions, depending on the type and direction of the interactions: (a) from the ecological to the social system (ecosystem service and disservice supply), (b) from the social to the ecological system (ecosystem service demand and human actions on the environment), and (c) bidirectionally between the social and the ecological system (social-ecological coupling). We recognize that relying on a single framework might be unrealistic, but understanding and generalizing the complexity of SESs requires common hierarchical analytical structures that comprehensively integrate the multiple dimensions and components of SESs (Reyers et al. 2017, Magliocca et al. 2018, Meyfroidt et al. 2018).

Third, regarding the feasibility of the variables for long-term monitoring (van Oudenhoven et al. 2018), our list facilitates SES characterization at the system level, i.e., it focuses on the macrolevels according to Binder et al. (2013) to integrate properties of the SES components as a whole. Aggregated variables at the system level have been clearly more used to characterize, map, and track SESs than variables collected at the individual level, i.e., variables focused on the microlevels according to Binder et al. (2013) to measure properties of the SES individual building blocks, e.g., plant, animal, individual producer, user, or consumer (see examples in Table A5.3). In fact, even those SES mapping strategies based on Ostrom's framework, which combines both system- and individual-level perspectives, i.e., macro- and microlevels according to Binder et al. (2013), have 
only used system level metrics (e.g., Dressel et al. 2018, Rocha et al. 2020). Several studies show that system-level characterizations can better inform on social-ecological processes from local to global scales (e.g., Václavík et al. 2013, Martín-López et al. 2017, Levers et al. 2018, Vallejos et al. 2020) and could help to overcome current limitations to upscale place-based research for the coproduction of generalizable knowledge on SES (Balvanera et al. 2017).

\section{Potential biases and gaps in the list of variables}

The analysis of the researchers' comments revealed potential conceptual biases introduced by the proposed framework during the construction of the list of variables (Fig. 4). In the interaction component, a majority of comments highlighted that sociocultural values and identities might be underrepresented and that the variables addressing the "strength of the links between people and nature" and the "cultural value of nature" could be enhanced, for instance, by incorporating the variable "local ecological knowledge." However, interestingly, cultural ecosystem service variables (following the categories of the Common International Classification of Ecosystem Services, CICES; Haines-Young and Potschin 2013) were not prioritized by researchers during the survey (Table A5.2, Appendix 5; Appendix 8). Although these findings may seem contradictory, they align with new insights into the nature's contributions to people (NCP) paradigm (Díaz et al. 2018) and the plurality of values associated with these contributions (UNEP 2015, Pascual et al. 2017). Under the new NCP paradigm, culture plays a central role in defining all links between people and nature (Díaz et al. 2018). Thus, further lists of SES variables should expand the ecosystem service supply dimension by giving culture and traditional/indigenous knowledge a more transversal role across ecosystem services categories, beyond the independent cultural category of CICES and the Millennium Assessment (MA 2005). Furthermore, enhancing the characterization of the cultural contexts and identities goes further for the instrumental values of ecosystem services and NCP by incorporating those values that emerge from individual and collective relationships of humans with nature (Chan et al. 2018). To address these "relational values," new variables, such as sense of belonging, responsibility toward nature, or maintenance of traditions (Chan et al. 2016), may be added to the list.

In the ecological system component, the explicit role of biodiversity might also be underrepresented because many comments suggested the addition of more biodiversity variables or of a whole biodiversity dimension within this component. Given the role of biodiversity in SESs as the natural capital that supports social metabolism (Costanza et al. 1997) and the biocentric conservationist tradition (Mace 2014), we agree that biodiversity could be explicitly named in the framework. However, we initially excluded the structural and compositional biodiversity facets because of their slower response to disturbances compared to functional variables (McNaughton et al. 1989, Milchunas and Lauenroth 1995). Instead, we focused on the functional aspects of biodiversity at the ecosystem level, such as the candidates to become essential biodiversity variables for the ecosystem function class (e.g., Pereira et al. 2013, Pettorelli et al. 2018).
We are also aware of additional sources of potential methodological biases. On the one hand, the way that the variables were sorted in our framework during the survey could have influenced respondents in assigning priority levels. By displaying the variables sorted into dimensions, we aimed to facilitate the completion of the survey. We are aware that a random display or other sorting could have led to different variable scores. However, this impact may have been low because there was no significant correlation between the priority scores and variable order in the online survey. On the other hand, because the field of expertise of most respondents was sustainability science and ecology (Appendix 9), the social variables might have received lower scores than expected. Indeed, the social variables never reached the highest priority level (level 1; Table A5.2, Appendix 5) despite their importance for human well-being and for explaining the form and intensity of human-nature interactions, e.g., education and population density, respectively (Ellis and Ramankutty 2008, Hamann et al. 2016). Most inter- and transdisciplinary efforts in social-ecology and sustainability science come from ecology (Lowe et al. 2009, Holzer et al. 2019), but a wide range of perspectives still exist among ecologists for integrating concepts and methods from social science. This disparity of perspectives might be because some researchers consider ecology as a basic science that studies wild nature (where people are only the "ecological audience"), others see it as an instrument for guiding ecosystem and species management (treating people as "ecological agents"), and still others view it as a discipline that considers human societies to be integrated in ecosystems (people as "ecological subjects/objects"; Lowe et al. 2009, Mace 2014). Indeed, these perceptions of ecology have been evidenced throughout the development and implementation of the longterm social-ecological monitoring network, which mainly originated from ecological monitoring and research. Despite the adoption of a new social-ecological paradigm, the network continues to monitor primarily ecological processes, although it is progressing toward incorporating economic and social data and conducting more germane transdisciplinary research (Dick et al. 2018, Angelstam et al. 2019). In our study, the potential coexistence of these three perceptions among the surveyed researchers could be the basis of the lack of consensus around the most relevant social variables. This highlights the need to strengthen cooperation between natural and social scientists and experts to lead to a truly integrated approach for long-term socialecological research (Dick et al. 2018). Finally, many scientists have reported difficulties in scoring the variables without considering a specific SES, arguing that variable relevance is context dependent. Although biodiversity, climate, oceans, or sustainable development goal variables may have more evident global perspectives, this is not easily applicable to SES variables given the place-based nature of SES research (Carpenter et al. 2012). All these potential biases should be considered when using our list of variables and formally analyzing them in future assessments.

\section{Toward the definition of essential variables for social-ecological systems}

The development of essential variables (EVs) that harmonize global observation networks is a priority for tracking changes and coordinating monitoring efforts (e.g., Pereira et al. 2013, Bojinski et al. 2014, Constable et al. 2016). Despite the call from 
sustainability science to extend this systemic thinking to areas of interaction between the social and the biophysical domains, building a list of essential social-ecological system variables is still needed (Reyers et al. 2017). The set of dimensions and variables developed here can contribute to creating a common structure to study SESs and to starting to work toward such essential variables. Because the variables and dimensions were based on consensual expert knowledge, their credibility, salience, and feasibility were reaffirmed (van Oudenhoven et al. 2018). In addition, fundamental steps in EV development were followed in the codesign process (Reyers et al. 2017): (1) adoption, through an expert-driven process, of a conceptual model of SESs functioning, representing the social and ecological systems as well as the interactions between them; (2) identification of the broad categories and disaggregated inputs of candidate variables; (3) refining and prioritization of variables based on the consensus on their relevance; and all this by means of (4) an iterative procedure fed by scientific expert knowledge obtained from workshops and online surveys. However, given the preliminary nature of our exercise, further work is needed to build a global consensus around a set of EVs for the study of SESs. For instance, new surveys should address the potential biases and limitations outlined above, for instance (1) by explicitly considering the role of biodiversity and of relational values about NCP; (2) by having a greater and more balanced number of respondents (particularly the inclusion of social scientists); and (3) by reporting on the most frequently relevant variables in relation to specific place-based social-ecological contexts.

To further develop EVs for SESs, finding common aspects and variables among the existing lists could also help to establish a baseline. Some variables suggested in Ostrom's (2009) and Frey's (2017) lists were also relevant in our study. The most common aspects were found for the interaction component. For instance, the harvesting variable on Ostrom's list was related to human appropriation of net primary production, material use, water use, or energy use on our list. Similarly, pollution patterns on Ostrom's list were related to eutrophication of water or net $\mathrm{CO}_{2}$ flux on our list; constructed facilities on Ostrom's list and accessibility on Frey's list were related to territorial connectivity, access to natural areas, or anthropogenic water management on our list; and importance of resources on Ostrom's list and dependency on resources on Frey's list with dependence on local natural capital on our list. In the social system, economic development and socioeconomic attributes (Ostrom 2009) were associated with poverty, educational level, or social equity variables on our list, and number of actors (Ostrom 2009) with population density. Similarly, governance-related variables, such as conflicts and political stability, were included on both Ostrom's list and our list, while Frey (2017) considered conflict management as a crucial aspect for the stability of rule systems and resource use. In the ecological system, Ostrom's (2009), Frey's (2017), and our list converged on including climate characteristics and primary productivity or the regeneration rate of resources.

In addition, some of our prioritized variables from the ecological and interaction components of SESs are related to six of the nine major environmental challenges listed in the planetary boundaries framework (Rockström et al. 2009, Steffen et al. 2015). For instance, the monitoring of net solar radiation and net $\mathrm{CO}_{2}$ flux could provide information to assess "climate change" and "atmospheric aerosol loading"; information on biological invasions, pest outbreak occurrence, and ecosystem composition by plant functional types to assess "changes in biosphere integrity"; measuring nitrogen deposition and eutrophication of water to evaluate interferences with "biogeochemical flows"; the appropriation of land for agriculture and land use intensity for "land-system change"; and finally, water use level and water use for irrigated crops to assess "freshwater use."

From a general perspective, additional steps should be given to foster the institutionalization of the development and implementation of essential SES variables (see Pereira et al. 2013, Bojinski et al. 2014, Constable et al. 2016, Reyers et al. 2017). As a first step, the compliance of the variables with the criteria to be considered essential should be thoroughly checked, for instance, to be (i) state variables, sensitive for long-term monitoring of changes; (ii) representative for the system level, between primary observations and indicators; (iii) flexible to adapt to multiple monitoring programs; and (iv) feasible to observe and derive and to be scaled to meet local, regional or subglobal needs. Second, consensus should be built and coordinated to align the development of the variable list with research and policy needs by setting an open platform for scientist, policy maker, and stakeholder cooperation. Third, the learning loop should be optimized to refine and stabilize the list of EVs by establishing a transparent process with specific targets and time lines to plan the development of the list and track the updates. Finally, to increase the global efficiency of Earth monitoring systems, the interconnection of the EVs that may emerge from our list with other sets of EVs (for biodiversity, climate, oceans, etc.) should be coordinated.

\section{CONCLUSION}

The development of reference lists of variables is an emerging need in sustainability research to foster the systematic collection of comprehensive and coordinated datasets of SESs and to enhance our ability to study SESs across time and space. These lists of variables structured under a conceptual framework provide a common language that facilitates comparisons and the generalization of knowledge from empirical studies. Although the development of such lists in specific fields of Earth systems (climate, biodiversity, oceans) has progressed significantly in recent years, integrative approaches for SESs are still scarce. With this study, we contributed to the identification of a common core set of variables for the characterization and monitoring of SESs. Our 60-variable list gathered relevant traits and processes of the SES from scientific literature reviews and expert knowledge. This list was embedded in a framework of 13 dimensions across the three key components of the SES (social system, ecological system, and the interactions between them) to help maintain an integrative approach when working with SESs. In addition, variables were classified into priority levels to provide more flexibility in their application to place-based research. Throughout this process, new insights have arisen that could contribute to overcoming existing barriers in the operationalization of lists of variables in the study of SESs, such as the applicability to place-based research, the capacity to deal with SES complexity, or the feasibility for long-term monitoring of social-ecological dynamics. Our list of variables may constitute a preliminary step in the direction of identifying essential variables for SESs, whose further development will provide an opportunity to boost the 
long-term social-ecological research network. This could strengthen our capacity to respond to global change challenges, extend systemic thinking to the field of human-nature interactions, and foster sustainability sciences through more efficient operationalization of the social-ecological approach.

Responses to this article can be read online at: http://www.ecologyandsociety.org/issues/responses. php/11676

\begin{abstract}
Acknowledgments:
We gratefully acknowledge the effort and ideas contributed by workshop participants (Appendix 2), especially to José Paruelo, Hugo Berbery, Howard Epstein, Julio Peñas, Antonio Castro, Esteban Jobbágy, and Néstor Fernández, as well as the commitment of those scientists who participated in the surveys (Appendix 9). We are also grateful to the two anonymous reviewers for their helpful comments, which substantially improved the manuscript. We thank the Spanish Ministry of Economy and Business (Project CGL2014-61610-EXP) for financial support, as well as the Spanish Ministry of Education for the MPR fellowship (FPU14/06782). This research was done within the LTSER platforms "The Arid Iberian South East LTSER Platform," Spain (LTER_EU_ES_027), and "Sierra Nevada/Granada (ES-SNE)," Spain (LTER_EU_ES_010), and contributes to the work done within the GEO BON working group on ecosystem services.
\end{abstract}

\section{Data Availability Statement:}

The aggregate data that support the findings of this study are available in the appendices of this paper. The individual responses to the survey conducted in this study are not publicly available because they contain information that could compromise the privacy of research participants.

\section{LITERATURE CITED}

Alessa, L., A. Kliskey, and G. Brown. 2008. Social-ecological hotspots mapping: a spatial approach for identifying coupled social-ecological space. Landscape and Urban Planning 85 (1):27-39. https://doi.org/10.1016/j.landurbplan.2007.09.007

Angelstam, P., M. Manton, M. Elbakidze, F. Sijtsma, M. C. Adamescu, N. Avni, P. Beja, P. Bezak, I. Zyablikova, F. Cruz, V. Bretagnolle, R. Díaz-Delgado, B. Ens, M. Fedoriak, G. Flaim, S. Gingrich, M. Lavi-Neeman, S. Medinets, V. Melecis, J. MuñozRojas, J. Schäckermann, A. Stocker-Kiss, H. Setälä, N. Stryamets, M. Taka, G. Tallec, U. Tappeiner, J. Törnblom, and T. Yamelynets. 2019. LTSER platforms as a place-based transdisciplinary research infrastructure: learning landscape approach through evaluation. Landscape Ecology 34(7):1461-1484. https://doi. org/10.1007/s10980-018-0737-6

Balvanera, P., R. Calderón-Contreras, A. J. Castro, M. R. FelipeLucia, I. R. Geijzendorffer, S. Jacobs, B. Martín-López, U. Arbieu, C. I. Speranza, B. Locatelli, N. P. Harguindeguy, I. R. Mercado, M. J. Spierenburg, A. Vallet, L. Lynes, and L. Gillson. 2017. Interconnected place-based social-ecological research can inform global sustainability. Current Opinion in Environmental Sustainability 29:1-7. https://doi.org/10.1016/j.cosust.2017.09.005

Balvanera, P., A. Cord, F. deClerck, E. Drakou, I. Geijzendorffer, G. Geller, D. Karp, B. Martín-Lopez, and T. Mwampamba. 2016. Essential ecosystem service variables. Abstract from GEO BON Open Science Conference, Leipzig, Germany.

Basurto, X., S. Gelcich, and E. Ostrom. 2013. The socialecological system framework as a knowledge classificatory system for benthic small-scale fisheries. Global Environmental Change 23 (6):1366-1380. https://doi.org/10.1016/j.gloenvcha.2013.08.001

Berkes, F., J. Colding, and C. Folke, editors. 2003. Navigating social-ecological systems: building resilience for complexity and change. Cambridge University Press, Cambridge, UK. https://doi. org/10.1017/CBO9780511541957

Berkes, F., C. Folke, and J. Colding. 2000. Linking social and ecological systems: management practices and social mechanisms for building resilience. Cambridge University Press, Cambridge, UK.

Binder, C., J. Hinkel, P. Bots, and C. Pahl-Wostl. 2013. Comparison of frameworks for analyzing social-ecological systems. Ecology and Society 18(4):26. http://dx.doi.org/10.5751/ ES-05551-180426

Bojinski, S., M. Verstraete, T. C. Peterson, C. Richter, A. Simmons, and M. Zemp. 2014. The concept of essential climate variables in support of climate research, applications, and policy. Bulletin of the American Meteorological Society 95(9):1431-1443. https://doi.org/10.1175/BAMS-D-13-00047.1

Carpenter, S. R., C. Folke, A. Norström, O. Olsson, L. Schultz, B. Agarwal, P. Balvanera, B. Campbell, J. C. Castilla, W. Cramer, R. DeFries, P. Eyzaguirre, T. P. Hughes, S. Polasky, Z. Sanusi, R. Scholes, and M. Spierenburg. 2012. Program on ecosystem change and society: an international research strategy for integrated social-ecological systems. Current Opinion in Environmental Sustainability 4(1):134-138. https://doi.org/10.1016/j.cosust.2012.01.001

Carpenter, S. R., H. A. Mooney, J. Agard, D. Capistrano, R. S. DeFries, S. Díaz, T. Dietz, A. K. Duraiappah, A. Oteng-Yeboah, H. M. Pereira, C. Perrings, W. V. Reid, J. Sarukhan, R. J. Scholes, and A. Whyte. 2009. Science for managing ecosystem services: beyond the Millennium Ecosystem Assessment. Proceedings of the National Academy of Sciences 106(5):1305-1312. [online] URL: https://doi.org/10.1073/pnas.0808772106

Castellarini, F., C. Siebe, E. Lazos, B. de la Tejera, H. Cotler, C. Pacheco, E. Boege, A. R. Moreno, A. Saldivar, A. Larrazábal, C. Galán, J. M. Casado, and P. Balvanera. 2014. A social-ecological spatial framework for policy design towards sustainability: Mexico as a study case. Investigación ambiental Ciencia y política pública $6(2)$.

Chan, K. M. A., P. Balvanera, K. Benessaiah, M. Chapman, S. Díaz, E. Gómez-Baggethun, R. Gould, N. Hannahs, K. Jax, S. Klain, G. W. Luck, B. Martín-López, B. Muraca, B. Norton, K. Ott, U. Pascual, T. Satterfield, M. Tadaki, J. Taggart, and N. Turner. 2016. Opinion: Why protect nature? Rethinking values and the environment. Proceedings of the National Academy of Sciences 113(6):1462-1465. https://doi.org/10.1073/pnas.1525002113 
Chan, K. M. A., R. K. Gould, and U. Pascual. 2018. Editorial overview: relational values: what are they, and what's the fuss about? Current Opinion in Environmental Sustainability 35:A1A7. https://doi.org/10.1016/j.cosust.2018.11.003

Chapin III, F. S., C. Folke, and G. P. Kofinas. 2009. A framework for understanding change. Pages 3-28 in C. Folke, G. P. Kofinas, and F. S. Chapin III, editors. Principles of ecosystem stewardship: resilience-based natural resource management in a changing world. Springer, New York, New York, USA. https://doi. org/10.1007/978-0-387-73033-2 1

Chapin III, F. S., A. L. Lovecraft, E. S. Zavaleta, J. Nelson, M. D. Robards, G. P. Kofinas, S. F. Trainor, G. D. Peterson, H. P. Huntington, and R. L. Naylor. 2006. Policy strategies to address sustainability of Alaskan boreal forests in response to a directionally changing climate. Proceedings of the National Academy of Sciences 103(45):16637-16643. https://doi.org/10.1073/ pnas.0606955103

Collins, S. L., S. R. Carpenter, S. M. Swinton, D. E. Orenstein, D. L. Childers, T. L. Gragson, N. B. Grimm, J. M. Grove, S. L. Harlan, J. P. Kaye, A. K. Knapp, G. P. Kofinas, J. J. Magnuson, W. H. McDowell, J. M. Melack, L. A. Ogden, G. P. Robertson, M. D. Smith, and A. C. Whitmer. 2011. An integrated conceptual framework for long-term social-ecological research. Frontiers in Ecology and the Environment 9(6):351-357. https://doi. org/10.1890/100068

Constable, A. J., D. P. Costa, O. Schofield, L. Newman, E. R. Urban, E. A. Fulton, J. Melbourne-Thomas, T. Ballerini, P. W. Boyd, A. Brandt, W. K. de la Mare, M. Edwards, M. Eléaume, L. Emmerson, K. Fennel, S. Fielding, H. Griffiths, J. Gutt, M. A. Hindell, E. E. Hofmann, S. Jennings, H. S. La, A. McCurdy, B. G. Mitchell, T. Moltmann, M. Muelbert, E. Murphy, A. J. Press, B. Raymond, K. Reid, C. Reiss, J. Rice, I. Salter, D. C. Smith, S. Song, C. Southwell, K. M. Swadling, A. Van de Putte, and Z. Willis. 2016. Developing priority variables ("ecosystem Essential Ocean Variables" - eEOVs) for observing dynamics and change in Southern Ocean ecosystems. Journal of Marine Systems 161:26-41. https://doi.org/10.1016/j.jmarsys.2016.05.003

Costanza, R., R. d'Arge, R. de Groot, S. Farber, M. Grasso, B. Hannon, K. Limburg, S. Naeem, R. V. O'Neill, J. Paruelo, R. G. Raskin, P. Sutton, and M. van den Belt. 1997. The value of the world's ecosystem services and natural capital. Nature 387:253-260. https://doi.org/10.1038/387253a0

Cox, M. 2014. Applying a social-ecological system framework to the study of the Taos Valley irrigation system. Human Ecology 42(2):311-324. https://doi.org/10.1007/s10745-014-9651-y

Delgado-Serrano, M. del M., and P. Ramos. 2015. Making Ostrom's framework applicable to characterise social ecological systems at the local level. International Journal of the Commons 9(2):808-830. https://doi.org/10.18352/ijc.567

Díaz, S., U. Pascual, M. Stenseke, B. Martín-López, R. T. Watson, Z. Molnár, R. Hill, K. M. A. Chan, I. A. Baste, K. A. Brauman, S. Polasky, A. Church, M. Lonsdale, A. Larigauderie, P. W. Leadley, A. P. E. van Oudenhoven, F. van der Plaat, M. Schröter, S. Lavorel, Y. Aumeeruddy-Thomas, E. Bukvareva, K. Davies, S. Demissew, G. Erpul, P. Failler, C. A. Guerra, C. L. Hewitt, H. Keune, S. Lindley, and Y. Shirayama. 2018. Assessing nature's contributions to people. Science 359(6373):270-272. https://doi. org/10.1126/science.aap8826

Dick, J., D. E. Orenstein, J. M. Holzer, C. Wohner, A.-L. Achard, C. Andrews, N. Avriel-Avni, P. Beja, N. Blond, J. Cabello, C. Chen, R. Díaz-Delgado, G. V. Giannakis, S. Gingrich, Z. Izakovicova, K. Krauze, N. Lamouroux, S. Leca, V. Melecis, K. Miklós, M. Mimikou, G. Niedrist, C. Piscart, C. Postolache, A. Psomas, M. Santos-Reis, U. Tappeiner, K. Vanderbilt, and G. Van Ryckegem. 2018. What is socio-ecological research delivering? A literature survey across 25 international LTSER platforms. Science of The Total Environment 622-623:1225-1240. https://doi.org/10.1016/j. scitotenv.2017.11.324

Dressel, S., G. Ericsson, and C. Sandström. 2018. Mapping socialecological systems to understand the challenges underlying wildlife management. Environmental Science \& Policy 84:105-112. https://doi.org/10.1016/j.envsci.2018.03.007

Ellis, E. C., and N. Ramankutty. 2008. Putting people in the map: anthropogenic biomes of the world. Frontiers in Ecology and the Environment 6(8):439-447. https://doi.org/10.1890/070062

Frey, U. J. 2017. A synthesis of key factors for sustainability in social-ecological systems. Sustainability Science 12(4):507-519. https://doi.org/10.1007/s11625-016-0395-Z

Guerra, C. A., L. Pendleton, E. G. Drakou, V. Proença, W. Appeltans, T. Domingos, G. Geller, S. Giamberini, M. Gill, H. Hummel, S. Imperio, M. McGeoch, A. Provenzale, I. Serral, A. Stritih, E. Turak, P. Vihervaara, A. Ziemba, and H. M. Pereira. 2019. Finding the essential: improving conservation monitoring across scales. Global Ecology and Conservation 18:e0601. https:// doi.org/10.1016/j.gecco.2019.e00601

Haines-Young, R., and M. Potschin. 2013. Common international classification of ecosystem services (CICES): consultation on version 4, August-December 2012. EEA Framework Contract No EEA/IEA/09/003. European Environment Agency, Copenhagen, Denmark. [online] URL: https://cices.eu/content/uploads/ sites/8/2012/07/CICES-V43_Revised-Final_Report_29012013.pdf

Hamann, M., R. Biggs, and B. Reyers. 2015. Mapping socialecological systems: identifying 'green-loop' and 'red-loop' dynamics based on characteristic bundles of ecosystem service use. Global Environmental Change 34:218-226. https://doi. org/10.1016/j.gloenvcha.2015.07.008

Hamann, M., R. Biggs, and B. Reyers. 2016. An exploration of human well-being bundles as identifiers of ecosystem service use patterns. PLoS ONE 11(10):e0163476. https://doi.org/10.1371/ journal.pone.0163476

Hinkel, J., M. E. Cox, M. Schlüter, C. R. Binder, and T. Falk. 2015. A diagnostic procedure for applying the social-ecological systems framework in diverse cases. Ecology and Society 20(1):32. http://dx.doi.org/10.5751/ES-07023-200132

Holling, C. S. 2001. Understanding the complexity of economic, ecological, and social systems. Ecosystems 4:390-405. https://doi. org/10.1007/s10021-001-0101-5

Holzer, J. M., C. M. Adamescu, C. Cazacu, R. Díaz-Delgado, J. Dick, P. F. Méndez, L. Santamaría, and D. E. Orenstein. 2019. Evaluating transdisciplinary science to open research- 
implementation spaces in European social-ecological systems. Biological Conservation 238:108228. https://doi.org/10.1016/j. biocon.2019.108228

Holzer, J. M., M. C. Adamescu, F. J. Bonet-García, R. DíazDelgado, J. Dick, J. M. Grove, R. Rozzi, and D. E. Orenstein. 2018. Negotiating local versus global needs in the International Long Term Ecological Research Network's socio-ecological research agenda. Environmental Research Letters 13(10):105003. https://doi.org/10.1088/1748-9326/aadec8

Jax, K. 2010. Ecosystem functioning. Cambridge University Press, Cambridge, UK. https://doi.org/10.1017/CBO9780511781216

Leslie, H. M., X. Basurto, M. Nenadovic, L. Sievanen, K. C. Cavanaugh, J. J. Cota-Nieto, B. E. Erisman, E. Finkbeiner, G. Hinojosa-Arango, M. Moreno-Báez, S. Nagavarapu, S. M. W. Reddy, A. Sánchez-Rodríguez, K. Siegel, J. J. UlibarriaValenzuela, A. H. Weaver, and O. Aburto-Oropeza. 2015. Operationalizing the social-ecological systems framework to assess sustainability. Proceedings of the National Academy of Sciences 112(19):5979-5984. https://doi.org/10.1073/pnas.1414640112

Levers, C., D. Müller, K. Erb, H. Haberl, M. R. Jepsen, M. J. Metzger, P. Meyfroidt, T. Plieninger, C. Plutzar, J. Stürck, P. H. Verburg, P. J. Verkerk, and T. Kuemmerle. 2018. Archetypical patterns and trajectories of land systems in Europe. Regional Environmental Change 18:715-732. https://doi.org/10.1007/ s10113-015-0907-X

Levin, S., T. Xepapadeas, A.-S. Crépin, J. Norberg, A. de Zeeuw, C. Folke, T. Hughes, K. Arrow, S. Barrett, G. Daily, P. Ehrlich, N. Kautsky, K.-G. Mäler, S. Polasky, M. Troell, J. R. Vincent, and B. Walker. 2013. Social-ecological systems as complex adaptive systems: modeling and policy implications. Environment and Development Economics 18(2):111-132. https://doi.org/10.1017/ $\underline{\mathrm{S} 1355770 \mathrm{X} 12000460}$

Liu, J., T. Dietz, S. R. Carpenter, C. Folke, M. Alberti, C. L. Redman, S. H. Schneider, E. Ostrom, A. N. Pell, J. Lubchenco, W. W. Taylor, Z. Ouyang, P. Deadman, T. Kratz, and W. Provencher. 2007. Coupled human and natural systems. Ambio 36(8):639-649. https://doi.org/10.1579/0044-7447(2007)36[639: CHANS]2.0.CO;2

Lowe, P., G. Whitman, and J. Phillipson. 2009. Ecology and the social sciences. Journal of Applied Ecology 46(2):297-305. https:// doi.org/10.1111/j.1365-2664.2009.01621.X

Maass, M., P. Balvanera, P. Bourgeron, M. Equihua, J. Baudry, J. Dick, M. Forsius, L. Halada, K. Krauze, M. Nakaoka, D. E. Orenstein, T. W. Parr, C. L. Redman, R. Rozzi, M. Santos-Reis, A. Swemmer, and A. Vădineanu. 2016. Changes in biodiversity and trade-offs among ecosystem services, stakeholders, and components of well-being: the contribution of the International Long-Term Ecological Research network (ILTER) to Programme on Ecosystem Change and Society (PECS). Ecology and Society 21(3):31. http://dx.doi.org/10.5751/ES-08587-210331

Mace, G. M. 2014. Whose conservation? Science 345 (6204):1558-1560. https://dx.doi.org/10.1126/science.1254704

Magliocca, N. R., E. C. Ellis, G. R. H. Allington, A. de Bremond, J. Dell'Angelo, O. Mertz, P. Messerli, P. Meyfroidt, R. Seppelt, and P. H. Verburg. 2018. Closing global knowledge gaps: producing generalized knowledge from case studies of socialecological systems. Global Environmental Change 50:1-14. https:// doi.org/10.1016/j.gloenvcha.2018.03.003

Martín-López, B., I. Palomo, M. García-Llorente, I. IniestaArandia, A. J. Castro, D. García Del Amo, E. Gómez-Baggethun, and C. Montes. 2017. Delineating boundaries of social-ecological systems for landscape planning: a comprehensive spatial approach. Land Use Policy 66:90-104. https://doi.org/10.1016/j. landusepol.2017.04.040

McGinnis, M. D., and E. Ostrom. 2014. Social-ecological system framework: initial changes and continuing challenges. Ecology and Society 19(2):30. https://doi.org/10.5751/ES-06387-190230

McNaughton, S. J., M. Oesterheld, D. A. Frank, and K. J. Williams. 1989. Ecosystem-level patterns of primary productivity and herbivory in terrestrial habitats. Nature 341:142-144. https:// doi.org/10.1038/341142a0

Meyfroidt, P., R. Roy Chowdhury, A. de Bremond, E. C. Ellis, K.-H. Erb, T. Filatova, R. D. Garrett, J. M. Grove, A. Heinimann, T. Kuemmerle, C. A. Kull, E. F. Lambin, Y. Landon, Y. le Polain de Waroux, P. Messerli, D. Müller, J. Ø. Nielsen, G. D. Peterson, V. Rodriguez García, M. Schlüter, B. L. Turner II, and P. H. Verburg. 2018. Middle-range theories of land system change. Global Environmental Change 53:52-67. https://doi.org/10.1016/j. gloenvcha.2018.08.006

Milchunas, D. G., and W. K. Lauenroth. 1995. Inertia in plant community structure: state changes after cessation of nutrientenrichment stress. Ecological Applications 5(2):452-458. https:// doi.org/10.2307/1942035

Millennium Ecosystem Assessment (MA). 2005. Ecosystems and human well-being: synthesis. Island, Washington, D.C., USA.

Mirtl, M., E. T. Borer, I. Djukic, M. Forsius, H. Haubold, W. Hugo, J. Jourdan, D. Lindenmayer, W. H. McDowell, H. Muraoka, D. E. Orenstein, J. C. Pauw, J. Peterseil, H. Shibata, C. Wohner, X. Yu, and P. Haase. 2018. Genesis, goals and achievements of Long-Term Ecological Research at the global scale: a critical review of ILTER and future directions. Science of The Total Environment 626:1439-1462. https://doi.org/10.1016/j. scitotenv.2017.12.001

Norström, A. V., P. Balvanera, M. Spierenburg, and M. Bouamrane. 2017. Programme on ecosystem change and society: knowledge for sustainable stewardship of social-ecological systems. Ecology and Society 22(1):47. https://doi.org/10.5751/ ES-09010-220147

Ostrom, E. 2009. A general framework for analyzing sustainability of social-ecological systems. Science 325 (5939):419-422. https://doi.org/10.1126/science.1172133

Pascual, U., P. Balvanera, S. Díaz, G. Pataki, E. Roth, M. Stenseke, R. T. Watson, E. Başak Dessane, M. Islar, E. Kelemen, V. Maris, M. Quaas, S. M. Subramanian, H. Wittmer, A. Adlan, S. Ahn, Y. S. Al-Hafedh, E. Amankwah, S. T. Asah, P. Berry, A. Bilgin, S. J. Breslow, C. Bullock, D. Cáceres, H. Daly-Hassen, E. Figueroa, C. D. Golden, E. Gómez-Baggethun, D. GonzálezJiménez, J. Houdet, H. Keune, R. Kumar, K. Ma, P. H. May, A. Mead, P. O'Farrell, R. Pandit, W. Pengue, R. Pichis-Madruga, F. Popa, S. Preston, D. Pacheco-Balanza, H. Saarikoski, B. B. 
Strassburg, M. van den Belt, M. Verma, F. Wickson, and N. Yagi. 2017. Valuing nature's contributions to people: the IPBES approach. Current Opinion in Environmental Sustainability 26-27:7-16. https://doi.org/10.1016/j.cosust.2016.12.006

Pereira, H. M., S. Ferrier, M. Walters, G. N. Geller, R. H. G. Jongman, R. J. Scholes, M. W. Bruford, N. Brummitt, S. H. M. Butchart, A. C. Cardoso, N. C. Coops, E. Dulloo, D. P. Faith, J. Freyhof, R. D. Gregory, C. Heip, R. Höft, G. Hurtt, W. Jetz, D. S. Karp, M. A. McGeoch, D. Obura, Y. Onoda, N. Pettorelli, B. Reyers, R. Sayre, J. P. W. Scharlemann, S. N. Stuart, E. Turak, M. Walpole, and M. Wegmann. 2013. Essential biodiversity variables. Science 339(6117):277-278. https://doi.org/10.1126/science.1229931

Pettorelli, N., H. Schulte to Bühne, A. Tulloch, G. Dubois, C. Macinnis-Ng, A. M. Queirós, D. A. Keith, M. Wegmann, F. Schrodt, M. Stellmes, R. Sonnenschein, G. N. Geller, S. Roy, B. Somers, N. Murray, L. Bland, I. Geijzendorffer, J. T. Kerr, S. Broszeit, P. J. Leitão, C. Duncan, G. El Serafy, K. S. He, J. L. Blanchard, R. Lucas, P. Mairota, T. J. Webb, and E. Nicholson. 2018. Satellite remote sensing of ecosystem functions: opportunities, challenges and way forward. Remote Sensing in Ecology and Conservation 4(2):71-93. https://doi.org/10.1002/ $\underline{\text { rse } 2.59}$

Redman, C. L., J. M. Grove, and L. H. Kuby. 2004. Integrating social science into the long-term ecological research (LTER) network: social dimensions of ecological change and ecological dimensions of social change. Ecosystems 7(2):161-171. https:// doi.org/10.1007/s10021-003-0215-Z

Resilience Alliance. 2007. Assessing resilience in social-ecological systems: Volume 2 supplementary notes to the practitioners workbook.

Reyers, B., M. Stafford-Smith, K.-H. Erb, R. J. Scholes, and O. Selomane. 2017. Essential variables help to focus sustainable development goals monitoring. Current Opinion in Environmental Sustainability 26-27:97-105. https://doi.org/10.1016/j.cosust.2017.05.003

Rocha, J., K. Malmborg, L. Gordon, K. Brauman, and F. DeClerck. 2020. Mapping social-ecological systems archetypes. Environmental Research Letters 15(3):034017. https://doi. org/10.1088/1748-9326/ab666e

Rockström, J., W. Steffen, K. Noone, Å. Persson, F. S. Chapin III, E. F. Lambin, T. M. Lenton, M. Scheffer, C. Folke, H. J. Schellnhuber, B. Nykvist, C. A. de Wit, T. Hughes, S. van der Leeuw, H. Rodhe, S. Sörlin, P. K. Snyder, R. Costanza, U. Svedin, M. Falkenmark, L. Karlberg, R. W. Corell, V. J. Fabry, J. Hansen, B. Walker, D. Liverman, K. Richardson, P. Crutzen, and J. A. Foley. 2009. A safe operating space for humanity. Nature 461:472-475. https://doi.org/10.1038/461472a

Scholz, R. W., and C. R. Binder. 2004. Principles of humanenvironment systems (HES) research. International Congress on Environmental Modelling and Software. Osnabrück, Germany. [online] URL: https://scholarsarchive.byu.edu/iemssconference/2004/ all/116

Shackleton, C. M., S. Ruwanza, G. K. Sinasson Sanni, S. Bennett, P. De Lacy, R. Modipa, N. Mtati, M. Sachikonye, and G. Thondhlana. 2016. Unpacking Pandora's Box: understanding and categorising ecosystem disservices for environmental management and human wellbeing. Ecosystems 19:587-600. https://doi.org/10.1007/s10021-015-9952-Z

Steffen, W., K. Richardson, J. Rockström, S. E. Cornell, I. Fetzer, E. M. Bennett, R. Biggs, S. R. Carpenter, W. de Vries, C. A. de Wit, C. Folke, D. Gerten, J. Heinke, G. M. Mace, L. M. Persson, V. Ramanathan, B. Reyers, and S. Sörlin. 2015. Planetary boundaries: guiding human development on a changing planet. Science 347(6223):1259855. https://doi.org/10.1126/science.1259855

UN Environment Programme (UNEP). 2015. IPBES/4/INF/1: preliminary guide regarding diverse conceptualization of multiple values of nature and its benefits, including biodiversity and ecosystem functions and services (deliverable 3(d)). Report of the Fourth Session of the Plenary of the Intergovernmental SciencePolicy Platform on Biodiversity and Ecosystem Services. UNEP, Kuala Lumpur, Malaysia. [online] URL: http://www.ipbes.net/ sites/default/files/downloads/IPBES-4-INF-13 EN.pdf

Václavík, T., F. Langerwisch, M. Cotter, J. Fick, I. Häuser, S. Hotes, J. Kamp, J. Settele, J. H. Spangenberg, and R. Seppelt. 2016. Investigating potential transferability of place-based research in land system science. Environmental Research Letters 11(9):095002. https://doi.org/10.1088/1748-9326/11/9/095002

Václavík, T., S. Lautenbach, T. Kuemmerle, and R. Seppelt. 2013. Mapping global land system archetypes. Global Environmental Change 23(6):1637-1647. https://doi.org/10.1016/j.gloenvcha.2013.09.004

Vallejos, M., S. Aguiar, G. Baldi, M. E. Mastrángelo, F. Gallego, M. Pacheco-Romero, D. Alcaraz-Segura, and J. M. Paruelo. 2020. Social-ecological functional types: connecting people and ecosystems in the Argentine Chaco. Ecosystems 23:471-484. https://doi.org/10.1007/s10021-019-00415-4

van Oudenhoven, A. P. E., M. Schröter, E. G. Drakou, I. R. Geijzendorffer, S. Jacobs, P. M. van Bodegom, L. Chazee, B. Czúcz, K. Grunewald, A. I. Lillebø, L. Mononen, A. J. A. Nogueira, M. Pacheco-Romero, C. Perennou, R. P. Remme, S. Rova, R.-U. Syrbe, J. A. Tratalos, M. Vallejos, and C. Albert. 2018. Key criteria for developing ecosystem service indicators to inform decision making. Ecological Indicators 95:417-426. https://doi. org/10.1016/j.ecolind.2018.06.020

Vargas, R., D. Alcaraz-Segura, R. Birdsey, N. A. Brunsell, C. O. Cruz-Gaistardo, B. de Jong, J. Etchevers, M. Guevara, D. J. Hayes, K. Johnson, H. W. Loescher, F. Paz, Y. Ryu, Z. Sanchez-Mejia, and K. P. Toledo-Gutierrez. 2017. Enhancing interoperability to facilitate implementation of REDD+: case study of Mexico. Carbon Management 8(1):57-65. https://doi.org/10.1080/175830$\underline{04.2017 .1285177}$ 
Appendix 1. List of key references used for identifying variables and dimensions for characterizing the social-ecological system (SES).

Key references on SES conceptual frameworks:

Binder, C., J. Hinkel, P. Bots, and C. Pahl-Wostl. 2013. Comparison of Frameworks for Analyzing Social-ecological Systems. Ecology and Society 18(4).

Chapin, F. S., A. L. Lovecraft, E. S. Zavaleta, J. Nelson, M. D. Robards, G. P. Kofinas, S. F. Trainor, G. D. Peterson, H. P. Huntington, and R. L. Naylor. 2006. Policy strategies to address sustainability of Alaskan boreal forests in response to a directionally changing climate. Proceedings of the National Academy of Sciences 103(45):16637-16643.

Delgado-Serrano, M. del M., and P. Ramos. 2015. Making Ostrom's framework applicable to characterise social ecological systems at the local level. International Journal of the Commons 9(2):808-830.

MA. 2005. Ecosystems and Human Well-being: Synthesis. Island Press, Washington, DC.

McGinnis, M., and E. Ostrom. 2014. Social-ecological system framework: initial changes and continuing challenges. Ecology and Society 19(2).

Ostrom, E. 2009. A General Framework for Analyzing Sustainability of Social-Ecological Systems. Science 325(5939):419-422.

Redman, C. L., J. M. Grove, and L. H. Kuby. 2004. Integrating Social Science into the LongTerm Ecological Research (LTER) Network: Social Dimensions of Ecological Change and Ecological Dimensions of Social Change. Ecosystems 7(2):161-171.

Resilience Alliance. 2007. Assessing resilience in social-ecological systems: Volume 2 supplementary notes to the practitioners workbook.

Scholz, R., and C. Binder. 2004. Principles of Human-Environment Systems (HES) Research. Pages 791-796 Complexity and integrated resources management. International Environmental Modelling and Software Society, [2004]. Osnabrück.

Key references on SES mapping:

Alessa, L., A. Kliskey, and G. Brown. 2008. Social-ecological hotspots mapping: A spatial approach for identifying coupled social-ecological space. Landscape and Urban Planning 85(1):27-39.

Asselen, S. van, and P. H. Verburg. 2012. A Land System representation for global assessments and land-use modeling. Global Change Biology 18(10):3125-3148. 
Castellarini, F., C. Siebe, E. Lazos, B. de la Tejera, H. Cotler, C. Pacheco, E. Boege, A. R. Moreno, A. Saldivar, A. Larrazábal, C. Galán, J. M. Casado, and P. Balvanera. 2014. A social-ecological spatial framework for policy design towards sustainability: Mexico as a study case. Investigación ambiental Ciencia y política pública 6(2).

Dittrich, A., R. Seppelt, T. Václavík, and A. F. Cord. 2017. Integrating ecosystem service bundles and socio-environmental conditions - A national scale analysis from Germany. Ecosystem Services 28:273-282.

Dressel, S., G. Ericsson, and C. Sandström. 2018. Mapping social-ecological systems to understand the challenges underlying wildlife management. Environmental Science \& Policy 84:105-112.

Ellis, E. C., and N. Ramankutty. 2008. Putting people in the map: anthropogenic biomes of the world. Frontiers in Ecology and the Environment 6(8):439-447.

Hamann, M., R. Biggs, and B. Reyers. 2015. Mapping social-ecological systems: Identifying 'green-loop' and 'red-loop' dynamics based on characteristic bundles of ecosystem service use. Global Environmental Change 34:218-226.

Hamann, M., R. Biggs, and B. Reyers. 2016. An Exploration of Human Well-Being Bundles as Identifiers of Ecosystem Service Use Patterns. PLOS ONE 11(10):e0163476.

Hanspach, J., J. Loos, I. Dorresteijn, D. J. Abson, and J. Fischer. 2016. Characterizing socialecological units to inform biodiversity conservation in cultural landscapes. Diversity and Distributions 22(8):853-864.

Levers, C., D. Müller, K. Erb, H. Haberl, M. R. Jepsen, M. J. Metzger, P. Meyfroidt, T. Plieninger, C. Plutzar, J. Stürck, P. H. Verburg, P. J. Verkerk, and T. Kuemmerle. 2018. Archetypical patterns and trajectories of land systems in Europe. Regional Environmental Change 18(3):715-732.

Martín-López, B., I. Palomo, M. García-Llorente, I. Iniesta-Arandia, A. J. Castro, D. García Del Amo, E. Gómez-Baggethun, and C. Montes. 2017. Delineating boundaries of socialecological systems for landscape planning: A comprehensive spatial approach. Land Use Policy 66:90-104.

Queiroz, C., M. Meacham, K. Richter, A. V. Norström, E. Andersson, J. Norberg, and G. Peterson. 2015. Mapping bundles of ecosystem services reveals distinct types of multifunctionality within a Swedish landscape. AMBIO 44(1):89-101.

Raudsepp-Hearne, C., G. D. Peterson, and E. M. Bennett. 2010. Ecosystem service bundles for analyzing tradeoffs in diverse landscapes. Proceedings of the National Academy of Sciences 107(11):5242-5247.

Renard, D., J. M. Rhemtulla, and E. M. Bennett. 2015. Historical dynamics in ecosystem service bundles. Proceedings of the National Academy of Sciences 112(43):13411-13416.

Rocha, J., K. Malmborg, L. Gordon, K. Brauman, and F. DeClerck. 2020. Mapping socialecological systems archetypes. Environmental Research Letters 15(3):034017. 
Sinare, H., L. J. Gordon, and E. Enfors Kautsky. 2016. Assessment of ecosystem services and benefits in village landscapes - A case study from Burkina Faso. Ecosystem Services 21:141-152.

Spake, R., R. Lasseur, E. Crouzat, J. M. Bullock, S. Lavorel, K. E. Parks, M. Schaafsma, E. M. Bennett, J. Maes, M. Mulligan, M. Mouchet, G. D. Peterson, C. J. E. Schulp, W. Thuiller, M. G. Turner, P. H. Verburg, and F. Eigenbrod. 2017. Unpacking ecosystem service bundles: Towards predictive mapping of synergies and trade-offs between ecosystem services. Global Environmental Change 47:37-50.

Václavík, T., S. Lautenbach, T. Kuemmerle, and R. Seppelt. 2013. Mapping global land system archetypes. Global Environmental Change 23(6):1637-1647.

Vallejos, M., S. Aguiar, G. Baldi, M. E. Mastrángelo, F. Gallego, M. Pacheco-Romero, D. Alcaraz-Segura, and J. M. Paruelo. 2020. Social-Ecological Functional Types: Connecting People and Ecosystems in the Argentine Chaco. Ecosystems 23(3): 471-484.

Other key references on SES science that inspired variable selection:

Arneth, A., C. Brown, and M. D. A. Rounsevell. 2014. Global models of human decision-making for land-based mitigation and adaptation assessment. Nature Climate Change 4(7):550557.

Carpenter, S. R., H. A. Mooney, J. Agard, D. Capistrano, R. S. DeFries, S. Díaz, T. Dietz, A. K. Duraiappah, A. Oteng-Yeboah, H. M. Pereira, C. Perrings, W. V. Reid, J. Sarukhan, R. J. Scholes, and A. Whyte. 2009. Science for managing ecosystem services: Beyond the Millennium Ecosystem Assessment. Proceedings of the National Academy of Sciences 106(5):1305-1312.

Cumming, G. S., A. Buerkert, E. M. Hoffmann, E. Schlecht, S. von Cramon-Taubadel, and T. Tscharntke. 2014. Implications of agricultural transitions and urbanization for ecosystem services. Nature 515(7525):50-57.

Erb, K.-H. 2012. How a socio-ecological metabolism approach can help to advance our understanding of changes in land-use intensity. Ecological Economics 76-341:8-14.

Fischer-Kowalski, M., F. Krausmann, and I. Pallua. 2014. A sociometabolic reading of the Anthropocene: Modes of subsistence, population size and human impact on Earth. The Anthropocene Review 1(1):8-33.

Foster, K. A., and W. R. Barnes. 2012. Reframing Regional Governance for Research and Practice. Urban Affairs Review 48(2):272-283.

Frey, U. J. 2017. A synthesis of key factors for sustainability in social-ecological systems. Sustainability Science 12(4):507-519.

Haines-Young, R., and M. Potschin. 2013. Common International Classification of Ecosystem Services (CICES): Consultation on Version 4, August-December 2012. 
Liu, J., T. Dietz, S. R. Carpenter, C. Folke, M. Alberti, C. L. Redman, S. H. Schneider, E. Ostrom, A. N. Pell, J. Lubchenco, W. W. Taylor, Z. Ouyang, P. Deadman, T. Kratz, and W. Provencher. 2007. Coupled Human and Natural Systems. AMBIO 36(8):639-650.

Shackleton, C. M., S. Ruwanza, G. K. Sinasson Sanni, S. Bennett, P. De Lacy, R. Modipa, N. Mtati, M. Sachikonye, and G. Thondhlana. 2016. Unpacking Pandora's Box: Understanding and Categorising Ecosystem Disservices for Environmental Management and Human Wellbeing. Ecosystems 19(4):587-600. 
Appendix 2. Workshop participants.

List of participants in workshop 1 - "Capturing the functioning of social-ecological systems" Venue: University of Granada (Spain)

Dates: $18^{\text {th }}-20^{\text {th }}$ November 2015

\begin{tabular}{|c|c|c|}
\hline Surname / name & Institution & Area of expertise \\
\hline Alcaraz-Segura, Domingo & $\begin{array}{l}\text { Universidad de Granada } \\
\text { (Spain) }\end{array}$ & $\begin{array}{l}\text { Remote sensing, } \\
\text { ecosystem ecology, } \\
\text { conservation biology }\end{array}$ \\
\hline Blanco-Sacristán, Javier & $\begin{array}{l}\text { Università degli Studi di } \\
\text { Milano-Bicocca (Italy) }\end{array}$ & $\begin{array}{l}\text { Remote sensing, } \\
\text { ecosystem functioning }\end{array}$ \\
\hline Berbery, Hugo & $\begin{array}{l}\text { University of Maryland } \\
\text { (USA) }\end{array}$ & $\begin{array}{l}\text { Land surface-atmosphere } \\
\text { interactions, climate } \\
\text { system, water and energy } \\
\text { budgets }\end{array}$ \\
\hline Cabello, Javier & $\begin{array}{l}\text { Universidad de Almería } \\
\text { (Spain) }\end{array}$ & $\begin{array}{l}\text { Sustainability, ecology and } \\
\text { conservation, ecosystem } \\
\text { functions and services }\end{array}$ \\
\hline Castro, Antonio & $\begin{array}{l}\text { Universidad de Almería } \\
\text { (Spain) }\end{array}$ & $\begin{array}{l}\text { Human-environment } \\
\text { relationships, } \\
\text { sustainability, social- } \\
\text { ecological systems }\end{array}$ \\
\hline Epstein, Howard & $\begin{array}{l}\text { University of Virginia } \\
\text { (USA) }\end{array}$ & $\begin{array}{l}\text { Ecosystem functioning, } \\
\text { vegetation dynamics, } \\
\text { climate change, carbon } \\
\text { cycling, carbon-water } \\
\text { interactions, disturbances } \\
\text { regime }\end{array}$ \\
\hline Fernández, Néstor & $\begin{array}{l}\text { German Centre for } \\
\text { Integrative Biodiversity } \\
\text { Research - iDiv } \\
\text { (Germany) }\end{array}$ & $\begin{array}{l}\text { Ecosystem functioning, } \\
\text { biodiversity and } \\
\text { conservation, ecological } \\
\text { modelling, remote sensing }\end{array}$ \\
\hline Jobbágy, Esteban & $\begin{array}{l}\text { Universidad Nacional de } \\
\text { San Luis (Argentina) }\end{array}$ & $\begin{array}{l}\text { Ecosystem ecology, } \\
\text { human control of } \\
\text { ecosystem processes, } \\
\text { ecohydrology }\end{array}$ \\
\hline
\end{tabular}




\begin{tabular}{|c|c|c|}
\hline Lourenço, Patricia & $\begin{array}{l}\text { Universidade de Évora } \\
\text { (Portugal) }\end{array}$ & $\begin{array}{l}\text { Ecosystem functioning, } \\
\text { remote sensing, } \\
\text { conservation biology }\end{array}$ \\
\hline Oyonarte, Cecilio & $\begin{array}{l}\text { Universidad de Almería } \\
\text { (Spain) }\end{array}$ & $\begin{array}{l}\text { Soil science, } \\
\text { geochemistry, carbon } \\
\text { dynamics, climate change }\end{array}$ \\
\hline Pacheco-Romero, Manuel & $\begin{array}{l}\text { Universidad de Almería } \\
\text { (Spain) }\end{array}$ & $\begin{array}{l}\text { Social-ecological systems, } \\
\text { sustainability }\end{array}$ \\
\hline Paruelo, José & $\begin{array}{l}\text { Universidad de Buenos } \\
\text { Aires (Argentina) }\end{array}$ & $\begin{array}{l}\text { Ecosystem structure and } \\
\text { functioning, ecological } \\
\text { modelling, remote sensing, } \\
\text { ecosystem services }\end{array}$ \\
\hline Peñas, Julio & $\begin{array}{l}\text { Universidad de Granada } \\
\text { (Spain) }\end{array}$ & $\begin{array}{l}\text { Conservation biology, } \\
\text { biodiversity, plant } \\
\text { ecology, biogeography }\end{array}$ \\
\hline Pérez-Cazorla, Beatriz & $\begin{array}{l}\text { Universidad de Almería } \\
\text { (Spain) }\end{array}$ & $\begin{array}{l}\text { Ecosystem functioning, } \\
\text { remote sensing, } \\
\text { conservation biology }\end{array}$ \\
\hline $\begin{array}{l}\text { Requena-Mullor, Juan } \\
\text { Miguel }\end{array}$ & $\begin{array}{l}\text { Boise State University } \\
\text { (USA) }\end{array}$ & $\begin{array}{l}\text { Ecological modelling, } \\
\text { conservation biology, } \\
\text { remote sensing }\end{array}$ \\
\hline Reyes, Andrés & $\begin{array}{l}\text { Universidad de Almería } \\
\text { (Spain) }\end{array}$ & $\begin{array}{l}\text { Ecosystem functioning, } \\
\text { remote sensing, } \\
\text { conservation biology }\end{array}$ \\
\hline
\end{tabular}

List of participants in Workshop 2 - "Towards the identification of Social-Ecological Functional Types"

Venue: University of Buenos Aires (Argentina)

Dates: $6^{\text {th }}-11^{\text {th }}$ February 2017

\begin{tabular}{|c|c|c|}
\hline Surname / name & Institution & Area of expertise \\
\hline Aguiar, Sebastián & $\begin{array}{l}\text { Universidad de Buenos } \\
\text { Aires (Argentina) }\end{array}$ & $\begin{array}{l}\text { Natural resource } \\
\text { management, territorial } \\
\text { planning, political } \\
\text { ecology, sustainability }\end{array}$ \\
\hline Alcaraz-Segura, Domingo & $\begin{array}{l}\text { Universidad de Granada } \\
\text { (Spain) }\end{array}$ & $\begin{array}{l}\text { Remote sensing, } \\
\text { ecosystem ecology, } \\
\text { conservation biology }\end{array}$ \\
\hline
\end{tabular}




\begin{tabular}{|c|c|c|}
\hline Bagnato, Camilo & $\begin{array}{l}\text { Universidad de Buenos } \\
\text { Aires (Argentina) }\end{array}$ & $\begin{array}{l}\text { Ecosystem functioning, } \\
\text { remote sensing, territorial } \\
\text { planning }\end{array}$ \\
\hline Blanco-Sacristán, Javier & $\begin{array}{l}\text { Università degli Studi di } \\
\text { Milano-Bicocca (Italy) }\end{array}$ & $\begin{array}{l}\text { Remote sensing, } \\
\text { ecosystem functioning }\end{array}$ \\
\hline Berbery, Hugo & $\begin{array}{l}\text { University of Maryland } \\
\text { (USA) }\end{array}$ & $\begin{array}{l}\text { Land surface-atmosphere } \\
\text { interactions, climate } \\
\text { system, water and energy } \\
\text { budgets }\end{array}$ \\
\hline Cabello, Javier & $\begin{array}{l}\text { Universidad de Almería } \\
\text { (Spain) }\end{array}$ & $\begin{array}{l}\text { Sustainability, ecology and } \\
\text { conservation, ecosystem } \\
\text { functions and services }\end{array}$ \\
\hline Epstein, Howard & $\begin{array}{l}\text { University of Virginia } \\
\text { (USA) }\end{array}$ & $\begin{array}{l}\text { Ecosystem functioning, } \\
\text { vegetation dynamics, } \\
\text { climate change, carbon } \\
\text { cycling, carbon-water } \\
\text { interactions, disturbances } \\
\text { regime }\end{array}$ \\
\hline Fernández, Néstor & $\begin{array}{l}\text { German Centre for } \\
\text { Integrative Biodiversity } \\
\text { Research - iDiv } \\
\text { (Germany) }\end{array}$ & $\begin{array}{l}\text { Ecosystem functioning, } \\
\text { biodiversity and } \\
\text { conservation, ecological } \\
\text { modelling, remote sensing }\end{array}$ \\
\hline Gallego, Federico & $\begin{array}{l}\text { Universidad de la } \\
\text { República de Uruguay } \\
\text { (Uruguay) }\end{array}$ & $\begin{array}{l}\text { Sustainability, natural } \\
\text { resource management, } \\
\text { social-ecological systems, } \\
\text { ecosystem services, } \\
\text { territorial planning }\end{array}$ \\
\hline Jobbágy, Esteban & $\begin{array}{l}\text { Universidad Nacional de } \\
\text { San Luis (Argentina) }\end{array}$ & $\begin{array}{l}\text { Ecosystem ecology, } \\
\text { human control of } \\
\text { ecosystem processes, } \\
\text { ecohydrology }\end{array}$ \\
\hline Pacheco-Romero, Manuel & $\begin{array}{l}\text { Universidad de Almería } \\
\text { (Spain) }\end{array}$ & $\begin{array}{l}\text { Social-ecological systems, } \\
\text { sustainability }\end{array}$ \\
\hline Paruelo, José & $\begin{array}{l}\text { Universidad de Buenos } \\
\text { Aires (Argentina) }\end{array}$ & $\begin{array}{l}\text { Ecosystem structure and } \\
\text { functioning, ecological } \\
\text { modelling, remote sensing, } \\
\text { ecosystem services }\end{array}$ \\
\hline Peñas, Julio & $\begin{array}{l}\text { Universidad de Granada } \\
\text { (Spain) }\end{array}$ & $\begin{array}{l}\text { Conservation biology, } \\
\text { biodiversity, plant } \\
\text { ecology, biogeography }\end{array}$ \\
\hline
\end{tabular}




$\begin{array}{lll}\text { Pérez-Cazorla, Beatriz } & \begin{array}{l}\text { Universidad de Almería } \\ \text { (Spain) }\end{array} & \begin{array}{l}\text { Ecosystem functioning, } \\ \text { remote sensing, } \\ \text { conservation biology }\end{array} \\ \text { Piñeiro, Gervasio } & \begin{array}{l}\text { Universidad de Buenos } \\ \text { Aires (Argentina) }\end{array} & \begin{array}{l}\text { Biodiversity, ecosystem } \\ \text { ecology, sustainability, } \\ \text { natural resource } \\ \text { management }\end{array} \\ \text { Vallejos, María } & \begin{array}{l}\text { Sustainability, natural } \\ \text { Universidad de Buenos } \\ \text { Aires (Argentina) }\end{array} & \begin{array}{l}\text { resource management, } \\ \text { social-ecological systems, } \\ \text { ecosystem services, } \\ \text { territorial planning }\end{array} \\ & & \end{array}$




\section{Essential variables to describe the functioning of Social-Ecological Systems}

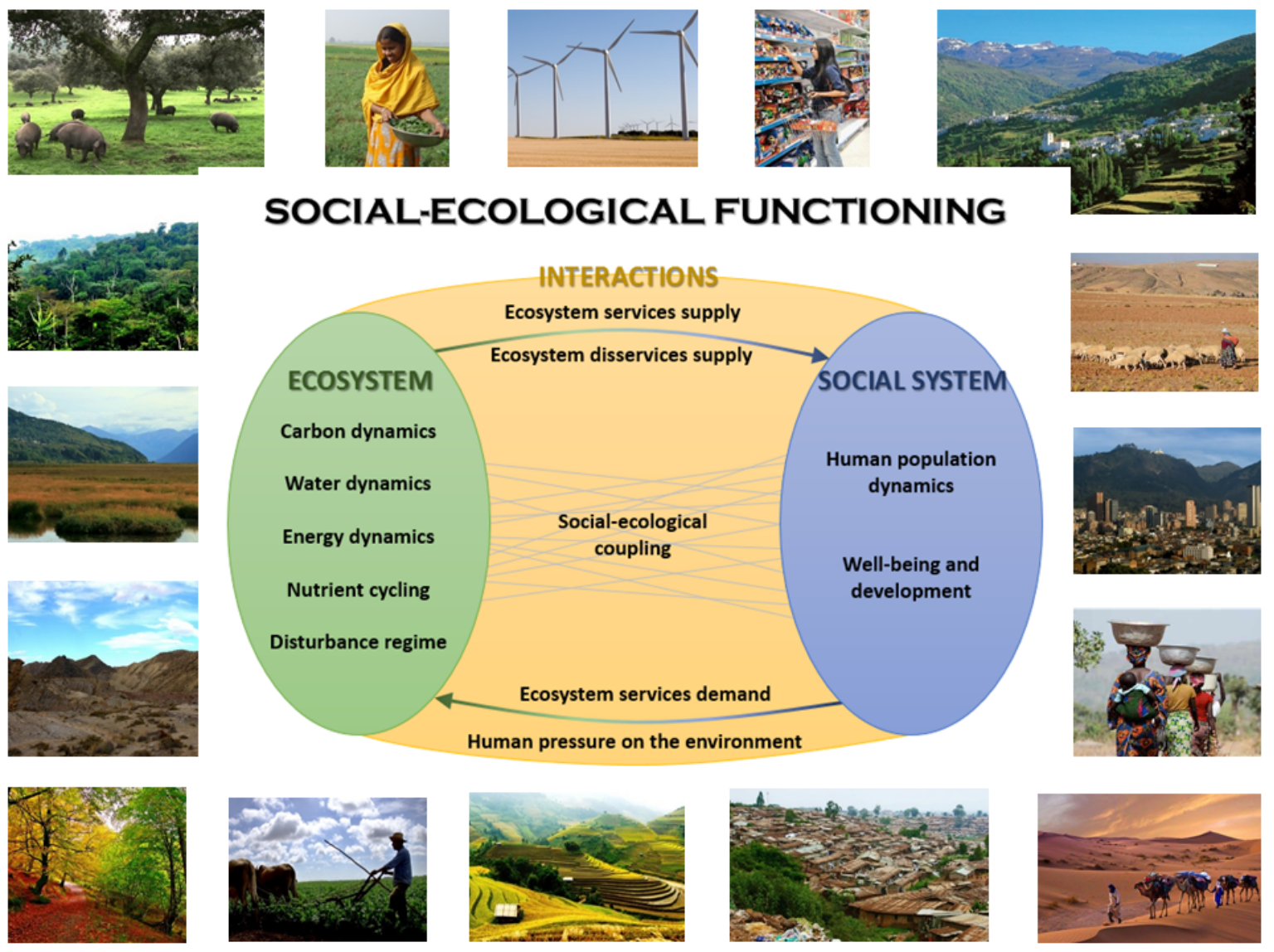

\section{Participating Institutions}

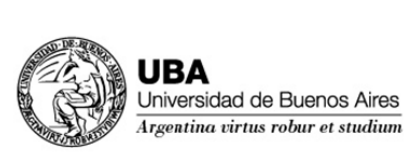

- iDiv

German Centre for Integrative Biodiversity Research
Halle-Jena-Leipzig

\section{CSIC}
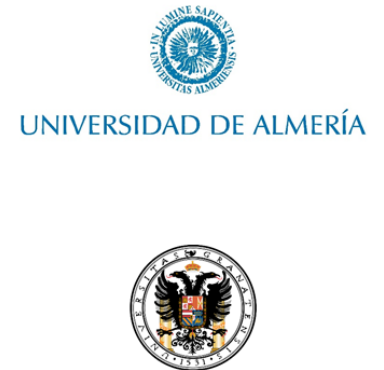

Universidad de Granada

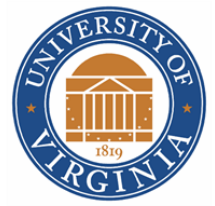
Universidad San Luis

\section{Introduction}

We aim to integrate biophysical and social processes to produce a functional characterization and mapping of social-ecological systems at the regional scale and landscape level. This survey aims to agree on a set of 'Essential Social-Ecological Functional Variables' (ESEFVs) to be used in such 
process.

A list of candidate variables is structured in three 'Components' of the social-ecological system (Social System, Ecosystem and Interactions) and each Component into several 'Functional Dimensions' (dimensions of the social system functioning, dimensions of ecosystem functioning, and dimensions of the interactions between the social system and the ecosystems). Possible indicators are shown in some cases only to exemplify, but the answers should focus on the variables (whatever the indicator is).

We ask you to select and punctuate only those variables that you consider essential to describe the functioning of social-ecological systems

We consider as essential those variables that encompass and integrate critical processes to characterize the functioning of social-ecological systems. Following GEOBON approach for Essential Biodiversity Variables, ESEFVs should be state variables, but useful for change monitoring. Also, they should be coherent and appropriate for comparing across social-ecological systems diversity. Spatially, these variables aim to target the ecosystem level and the human community level. Ideally, they should be already available or technically feasible and economically viable for regional or global implementation in monitoring programs, regional land-use planning, and sustainability and resilience assessment. Please, feel free to visit 'E\&SEFT Project' webpage (http://functionalty.pes.caescg.org/) to know about project goals, scientists involved, and other partners.

\section{Personal data (optional)}

In any case, your answers will be treated as confidential

1. First name:

\section{Last name:}

\section{Institution/Department:}

4. e-mail:

\section{Area of expertise:}

Selecciona todos los que correspondan.

Biophysical sciences

Social sciences

Sustainability Science

Environmental management / Territorial planning

Remote sensing

Biodiversity Science

Otro: 
6. Tick if you want to be acknowledged in derived publications:

Selecciona todos los que correspondan.

Yes, include my name in the acknowledgments

7. Tick if you want to receive the results of this study:

Selecciona todos los que correspondan.

Yes, send to me the results of this study

\section{COMPONENT 1. SOCIAL SYSTEM}

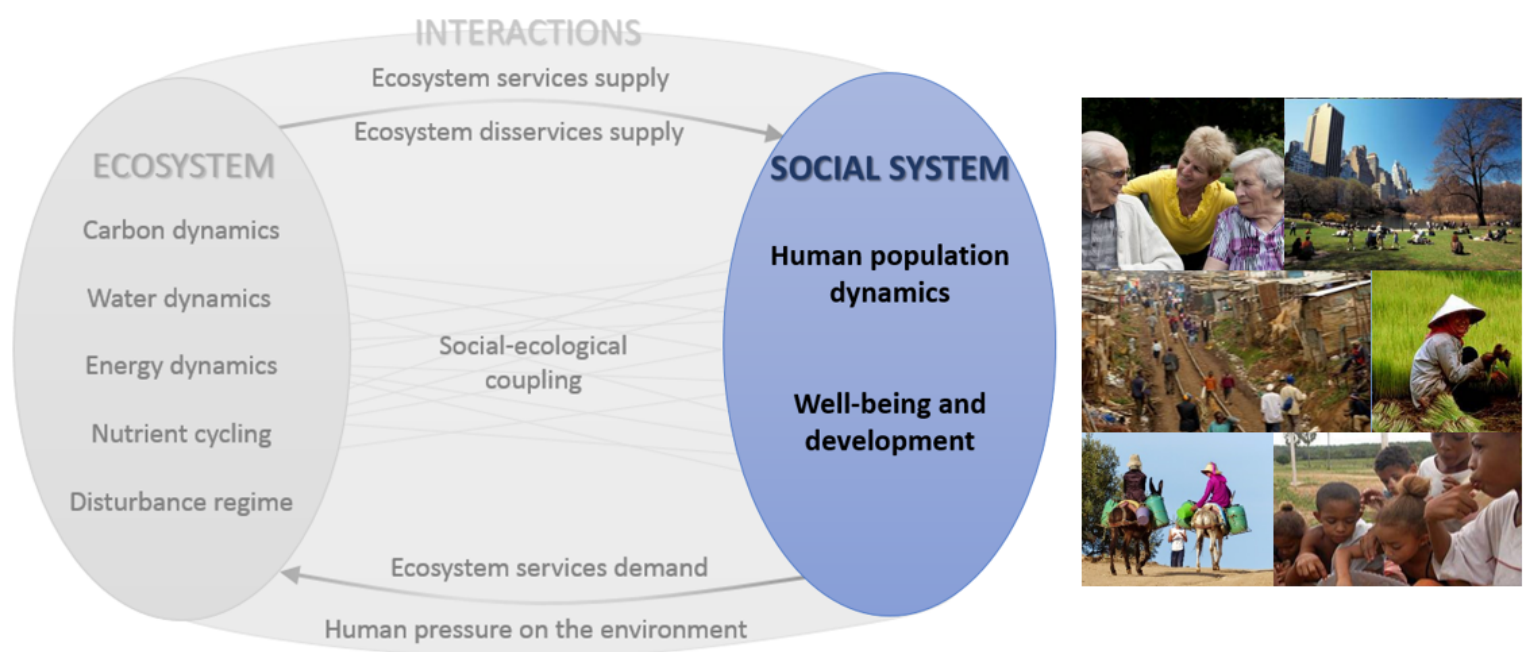

\section{Dimension 1a. Human population dynamics}

(You are in: Component 1. Social System)

8. In your opinion, which variables that describe human population dynamics are essential to characterize social-ecological systems functioning?

Please, punctuate each variable according to its relevance for being considered as 'Essential Social-Ecological Functional Variable' (from 1 "less essential" to 5 "more essential")

Marca solo un óvalo por fila.

No essential $1122 \quad 3 \quad 4 \quad 4 \quad 5$

Population size
Population density
Population distribution (e.g.:
rural population vs. \% urban
population)
Age structure (e.g.: median age,
population ageing index)
Sex Ratio
Human migrations (e.g.: \% of
inmigrants/emigrants in a
population)


9. Would you add/modify any variable of human population dynamics to better describe social-ecological systems functioning? Please specify:

\section{Dimension $1 \mathrm{~b}$. Well-being and development}

(You are in: Component 1. Social System)

10. In your opinion, which variables that describe human well-being and development are essential to characterize social-ecological systems functioning?

Please, punctuate each variable according to its relevance for being considered as 'Essential Social-Ecological Functional Variable' (from 1 "less essential" to 5 "more essential")

Marca solo un óvalo por fila.

$\begin{array}{llllll}\text { No essential } & 1 & 2 & 3 & 4 & 5\end{array}$

Life expectancy (e.g.: life
expectancy at birth)
Mortality (e.g.: infant mortality
rate)
Access to drinking water (e.g.:
distance to drinking water)
Electricity access
Water sanitation (e.g.: \% of
houses using improved sanitation
facilities)
Overcrowding (e.g.: people/
Employment (e.g.: economically
active population)
Economic level of the population
(e.g.: income per house/ per
Eapita)
(e.g.: illiteracy rate, \% of
population with higher education,
school enrolment rate, out of
school rate for adolescents)
Social equality (e.g.: wealth
distribution, women participation in
goverment, women literacy rate)
Institutional diversity
Access to internet
Environmental quality (e.g.: air,
water and soil pollution levels)
Land protection (\% of protected
area)


11. Would you add/modify any variable of social well-being and development to better describe social-ecological systems functioning? Please specify:

\section{COMPONENT 2. ECOSYSTEM}

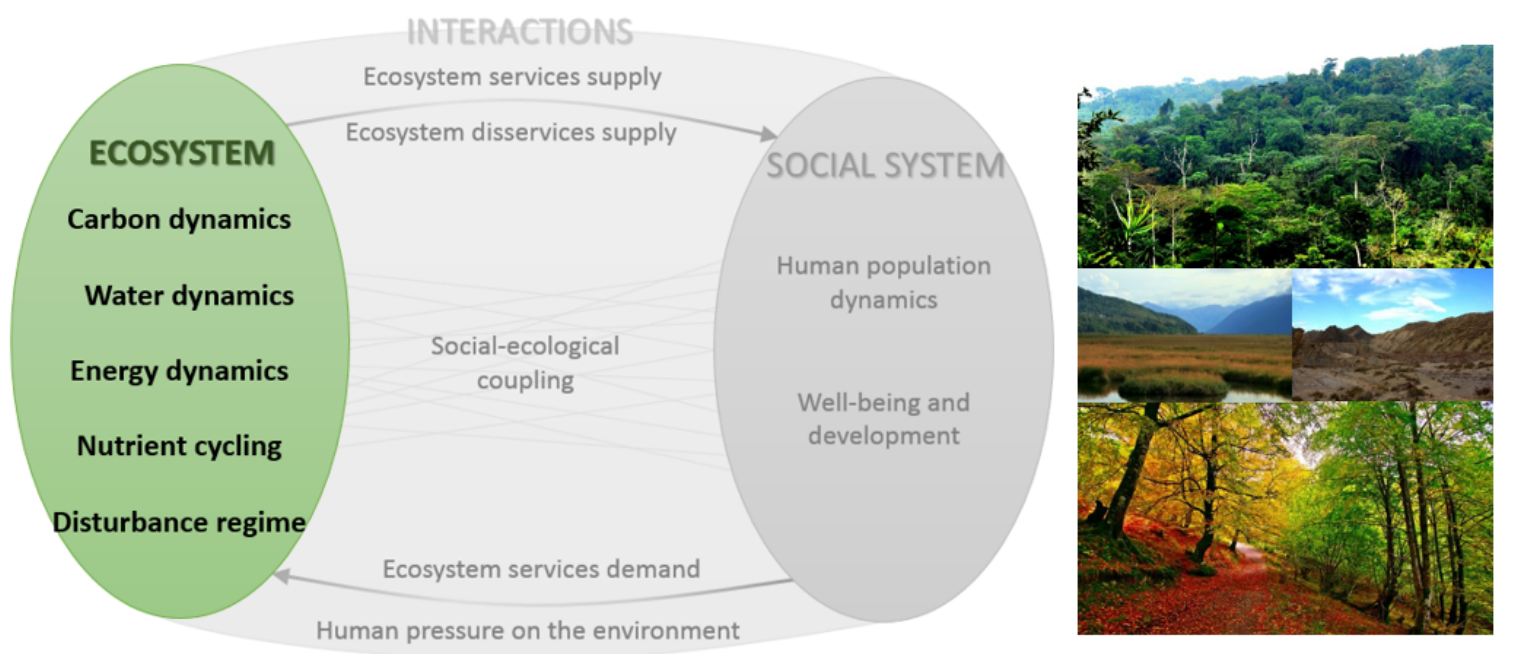

\section{Dimension 2a. Carbon dynamics}

(You are in: Component 2. Ecosystem)

12. Do you consider Net Primary Productivity as essential to characterize social-ecological systems functioning?

Please, punctuate this variable according to its relevance for being considered as 'Essential

Social-Ecological Functional Variable' (from 1 "less essential" to 5 "more essential")

Marca solo un óvalo por fila.

Net Primary Productivity

13. Would you add/modify any variable of carbon dynamics to better describe socialecological systems functioning? Please specify:

\section{Dimension 2b. Water dynamics}


14. Do you consider evapotranspiration as essential to characterize social-ecological systems functioning?

Please, punctuate this variable according to its relevance for being considered as 'Essential Social-Ecological Functional Variable' (from 1 "less essential" to 5 "more essential")

Marca solo un óvalo por fila.

Evapotranspiration

15. Would you add/modify any variable of water dynamics to better describe social-ecological systems functioning? Please specify:

\section{Dimension 2c. Energy dynamics}

(You are in: Component 2. Ecosystem)

16. In your opinion, which variables that describe energy dynamics are essential to characterize social-ecological systems functioning?

Please, punctuate each variable according to its relevance for being considered as 'Essential Social-Ecological Functional Variable' (from 1 "less essential" to 5 "more essential")

Marca solo un óvalo por fila.

No essential
Land surface energy balance
Albedo

17. Would you add/modify any variable of energy dynamics to better describe socialecological systems functioning? Please specify:

\section{Dimension 2d. Nutrient cycling}

(You are in: Component 2. Ecosystem) 
18. In your opinion, which variables that describe nutrient cycling are essential to characterize social-ecological systems functioning?

Please, punctuate each variable according to its relevance for being considered as 'Essential

Social-Ecological Functional Variable' (from 1 "less essential" to 5 "more essential")

Marca solo un óvalo por fila.

Nitrogen cycling

19. Would you add/modify any variable of nutrient cycling to better describe social-ecological systems functioning? Please specify:

\section{Dimension 2e. Disturbance regime}

(You are in: Component 2. Ecosystem)

20. In your opinion, which variables that describe disturance regime are essential to characterize social-ecological systems functioning?

Please, punctuate each variable according to its relevance for being considered as 'Essential Social-Ecological Functional Variable' (from 1 "less essential" to 5 "more essential")

Marca solo un óvalo por fila.

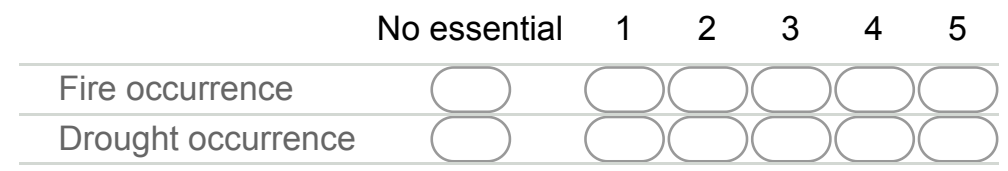

21. Would you add/modify any variable of disturbance regime to better describe socialecological systems functioning? Please specify: 
INTERACTIONS

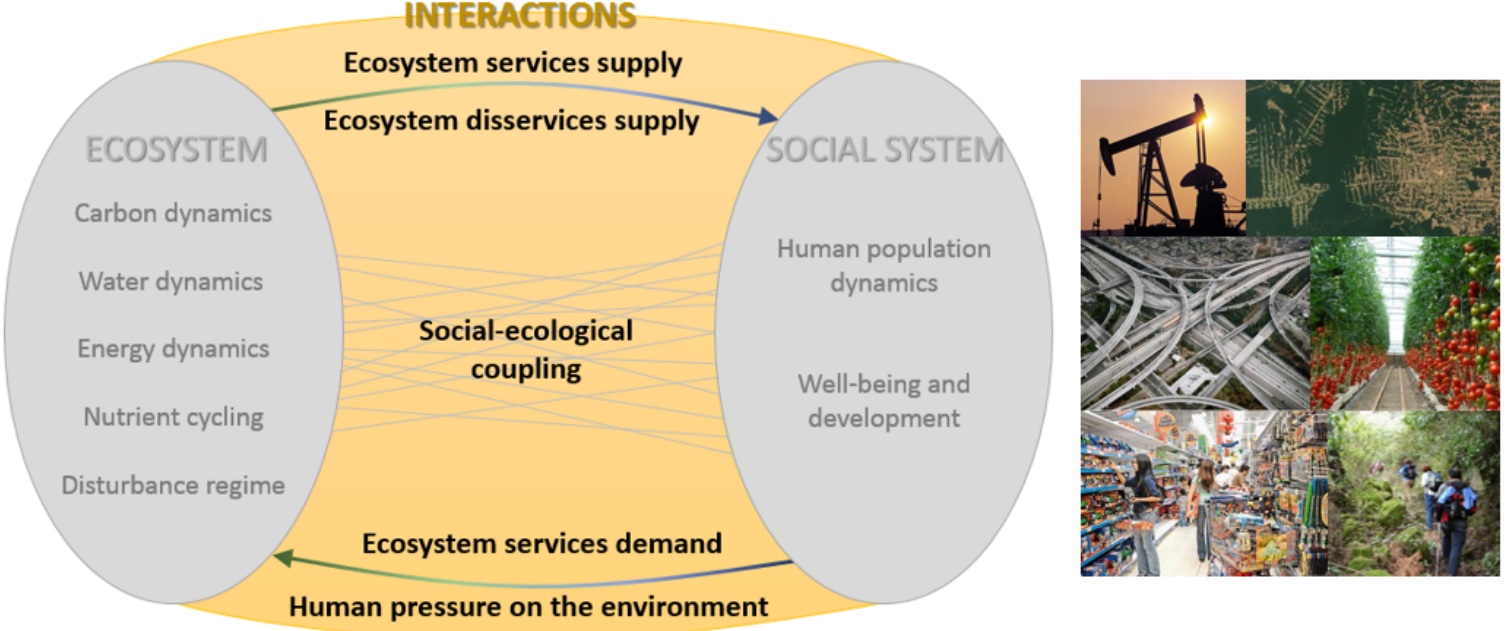

\section{Dimension 3a. Ecosystem services supply}

(You are in: Component 3. Interactions)

\section{In your opinion, which variables that describe provisioning services supply are essential to characterize social-ecological systems functioning?}

Please, punctuate each variable according to its relevance for being considered as 'Essential Social-Ecological Functional Variable' (from 1 "less essential" to 5 "more essential")

Marca solo un óvalo por fila.

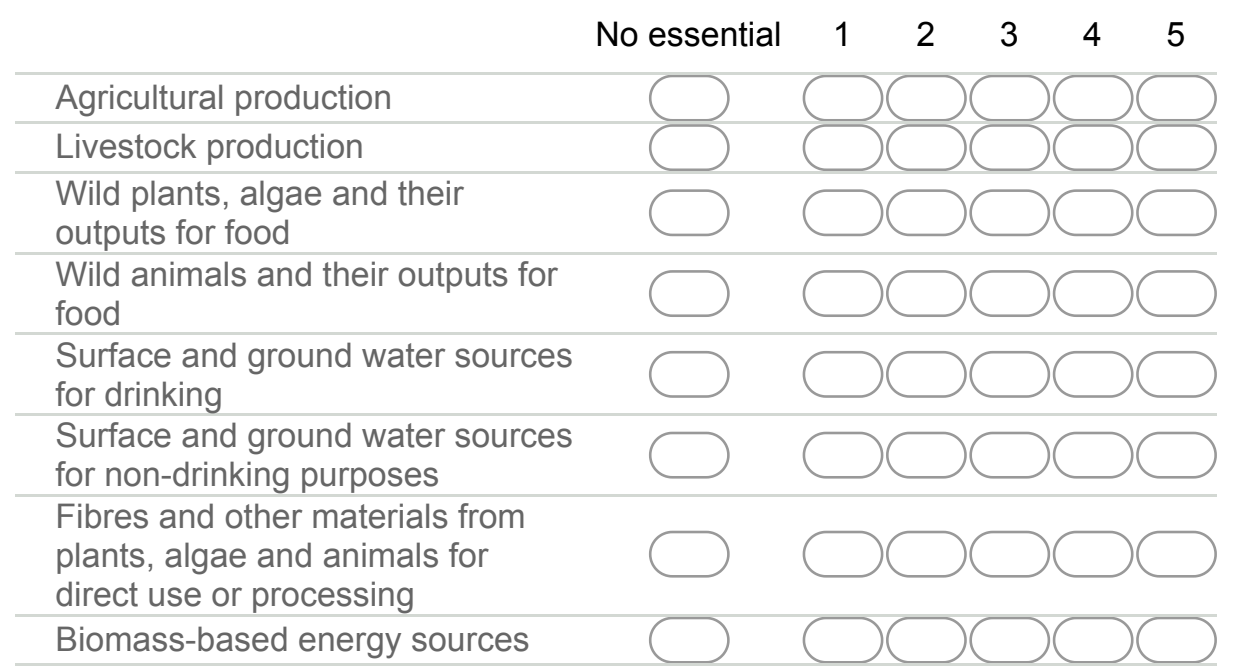


23. In your opinion, which variables that describe regulation \& maintenance services supply are essential to characterize social-ecological systems functioning?

Please, punctuate each variable according to its relevance for being considered as 'Essential Social-Ecological Functional Variable' (from 1 "less essential" to 5 "more essential")

Marca solo un óvalo por fila.

No essential $1 \quad 2 \quad 2 \quad 3 \quad 4 \quad 5$

Bio-remediation/ filtration/

sequestration/ storage/

accumulation by micro-organisms,

algae, plants, and animals (of

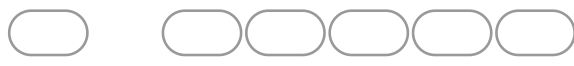

waste, toxics and other nuisances)

Mass stabilisation and control of

erosion rates

Hydrological cycle and water flow

maintenance

Ventilation and transpiration

Pollination and seed dispersal

Pest and disease control

Weathering, decomposition and

fixing rates (for soil formation)

Chemical conditions maintenance

of freshwaters and salt waters

Global climate regulation (by

reduction of greenhouse gas

concentrations)

24. In your opinion, which variables that describe cultural services supply are essential to characterize social-ecological systems functioning?

Please, punctuate each variable according to its relevance for being considered as 'Essential Social-Ecological Functional Variable' (from 1 "less essential" to 5 "more essential")

Marca solo un óvalo por fila.

No essential $1 \quad 2 \quad 3 \quad 4 \quad 5$

Physical and experiential

interactions (with plants, animals,

landscapes, seascapes)

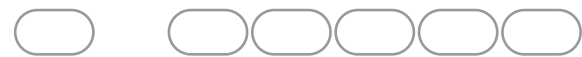

Intellectual and representative

interacions (scientific, educational,

heritage and cultural,

entertainment, aesthetic

contemplation)

Spiritual and/or emblematic

(symbolic, sacred and/or religious)

interactions

25. Would you add/modify any variable of ecosystem services supply to better describe social-ecological systems functioning? Please specify:

\section{Dimension 3b. Ecosystem disservices supply}

(You are in: Component 3. Interactions) 
26. In your opinion, which variables that describe ecosystem disservices supply are essential to characterize social-ecological systems functioning?

Please, punctuate each variable according to its relevance for being considered as 'Essential Social-Ecological Functional Variable' (from 1 "less essential" to 5 "more essential")

Marca solo un óvalo por fila.

No essential $1 \quad 2 \quad 2 \quad 3 \quad 4 \quad 5$

Bio-economic (e.g.: biological

invasions, agricultural and

fisheries pests and diseases

incidence, red tydes)

Abiotic-economic (e.g.: droughts

and fires occurrence, siltation,

leaching of nutrients)

Bio-health (e.g.: human diseases

incidence from pathogens,

allergens)

Abiotic-health (e.g.: flood and

storm events occurrence )

Bio-cultural (e.g.: bird droppings

on outdoor sculptures, tree roots

cracking pavements)

Abiotic-cultural (e.g.: soil erosion

rates, mud/landslide scar events,

unpleasant odours from rotting

organic matter)

It is noted that this candidate variables express the incidence of different kinds of harmful events. For simplicity, they have been classified according to their origin and primary dimension of human wellbeing affected, following Shackleton et al. (2016) approach.

27. Would you add/modify any variable of ecosystem disservices supply to better describe social-ecological systems functioning? Please specify:

\section{Dimension 3c. Ecosystem services demand}

(You are in: Component 3. Interactions) 
28. In your opinion, which variables that describe the human capture of ecosystem goods and services are essential to characterize social-ecological systems functioning?

Please, punctuate each variable according to its relevance for being considered as 'Essential Social-Ecological Functional Variable' (from 1 "less essential" to 5 "more essential")

Marca solo un óvalo por fila.

No essential $\quad 1 \quad 2 \quad 3 \quad 4 \quad 5$

Human Appropriation of Net

Primary Production (e.g.: Tn C extracted/ha/year)

Material use level (e.g.: raw

materials consumed per capita/

per year)

Energy use level (e.g.: energy

consumed per capita/ per year)

Water use level (e.g.: water

consumed per capita/ per year)
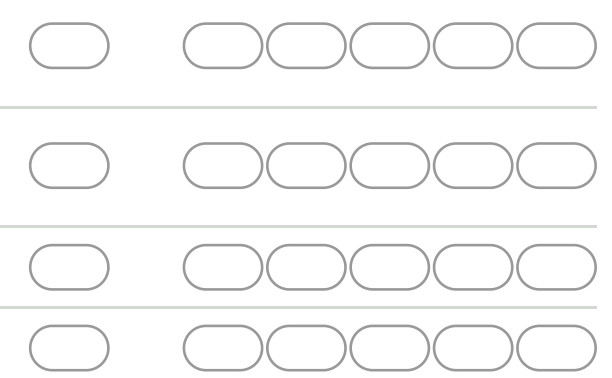

29. Would you add/modify any variable of ecosystem services demand to better describe social-ecological systems functioning? Please specify:

\section{Dimension 3d. Human pressure on the environment}

(You are in: Component 3. Interactions)

30. In your opinion, which variables that describe the human pressure on environment are essential to characterize social-ecological systems functioning?

Please, punctuate each variable according to its relevance for being considered as 'Essential Social-Ecological Functional Variable' (from 1 "less essential" to 5 "more essential")

Marca solo un óvalo por fila.

Isolation (e.g.: distance to main
roads, travel time to major cities)
Land use intensity
Carbon dioxide emissions
$\begin{aligned} & \text { Pollution (toxic emissions and } \\ & \text { spills) }\end{aligned}$

31. Would you add/modify any variable of human pressure on environment to better describe social-ecological systems functioning? Please specify: 
32. In your opinion, which variables that describe the degree of connection of a community to its local environment are essential to characterize social-ecological systems functioning?

Please, punctuate each variable according to its relevance for being considered as 'Essential Social-Ecological Functional Variable' (from 1 "less essential" to 5 "more essential") Marca solo un óvalo por fila.

No essential $1 \quad 2 \quad 2 \quad 3 \quad 4 \quad 5$

Weight of farming [industry,
services] sector in the economy
Population employed in farming
[industry, services] sectors
Land tenure structure (e.g.:
communal lands)
Local natural capital dependence
(e.g.: \% of final ecosystem
services consumed by the
population that are provided
directly by local environment)
Dependence on fossil energies
(e.g.: \% of energy consumed
coming from fossil resources)
Renewable energy use (e.g.: \% of
energy consumed coming from
renewable sources)
Non-ecosystem services demand
(e.g.: socioeconomic services like
hospitals, schools, culture,
internet)
Weight in the economy of the non-
ecosystem services market
Human perception of ecosystem
services
Access to natural or seminatural
areas (e.g.: distance to a natural
or seminatural area)
Human population ethnicity (e.g.:
\% of indigenous population)
Local green initiatives (e.g.: in
agriculture, cities, touristic
activities, local companies)
Import [export] rates
Airports [ports] activity

33. Would you add/modify any variable of social-ecological coupling to better describe socialecological systems functioning? Please specify: 


\section{Essential variables to characterize the functioning of Social-Ecological Systems}
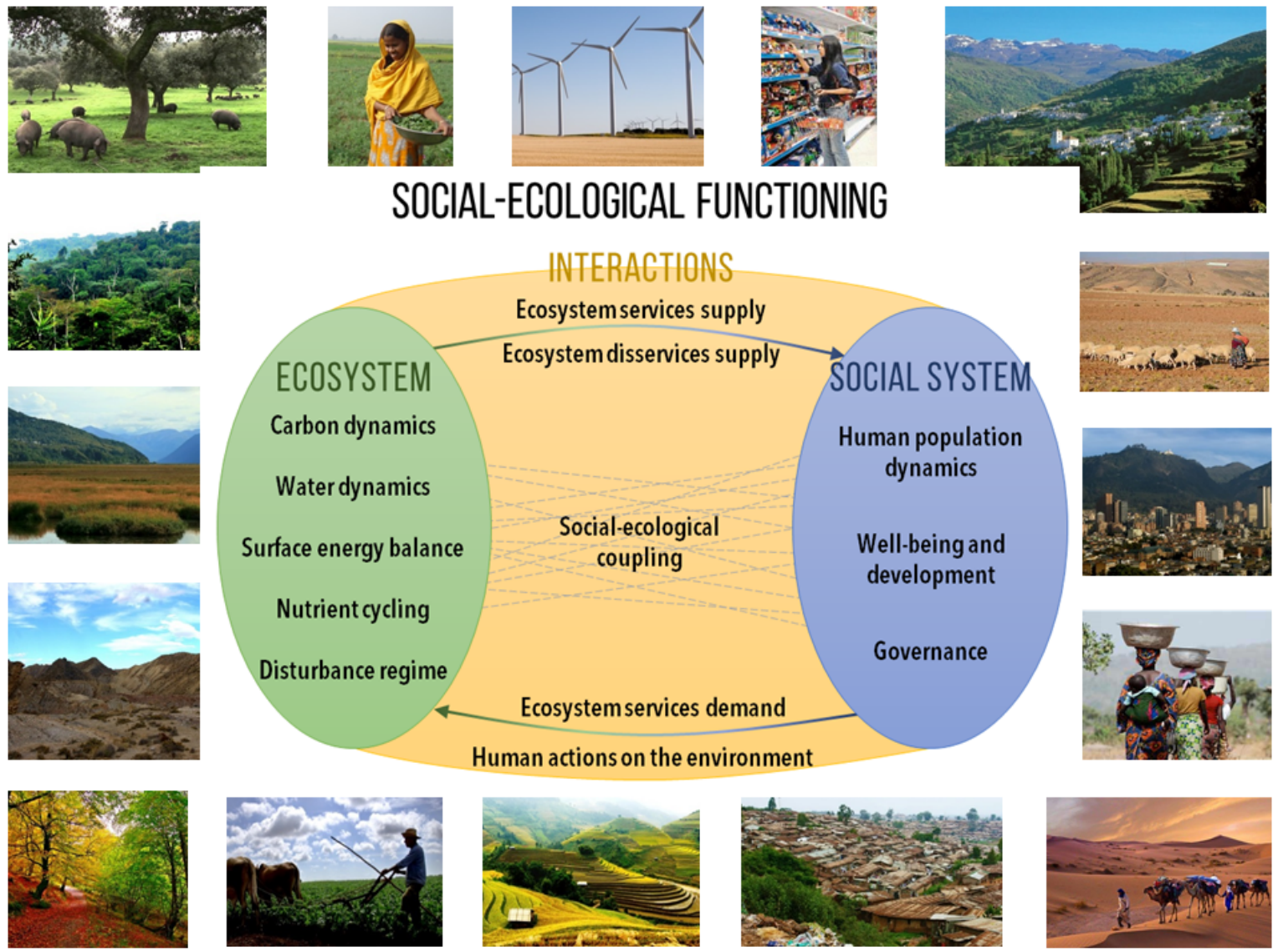

\section{Participating Institutions}

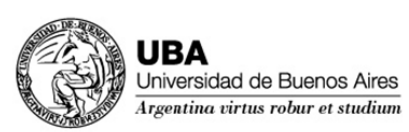

- iDiv

German Centre for Integrativ Biodiversity Research (iDiv) Halle-Jena-Leipzig

\section{CSIC}
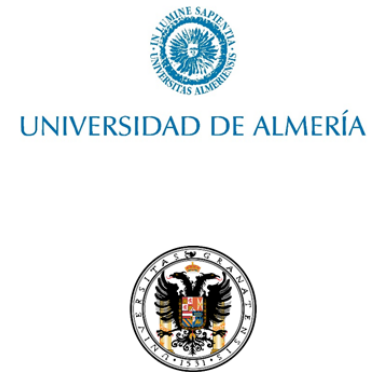

Universidad de Granada

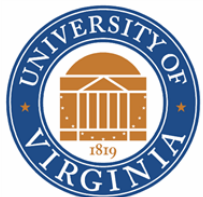

Universidad

San Luis

\section{Introduction}

This survey aims to collect expert opinions and knowledge about key variables to characterize socialecological systems functioning. 
The list of candidate variables is structured in three 'Components' of the social-ecological system (Social System, Ecosystem and Interactions) and each Component into several 'Functional Dimensions' (dimensions of the social system functioning, dimensions of ecosystem functioning, and dimensions of the interactions between the social system and the ecosystem). Possible indicators are shown in some cases only to exemplify, but the answers should focus on the variables.

We ask you to punctuate each variable according to its relevance to characterize the functioning of social-ecological systems. A key aspect to deal with is the issue of context-dependence. We are aware of the difficulties to assess the relevance of proposed variables without bearing in mind any specific social-ecological system. However, we call for a common effort to identify those variables that better explain the differences among social-ecological systems across the world.

We consider as essential those variables that encompass and integrate critical processes to characterize the functioning of social-ecological systems. They should be coherent and appropriate for comparing across social-ecological systems diversity. Spatially, these variables aim to target the ecosystem level and the human community level. Ideally, they should be viable for regional or global implementation in monitoring programs, regional land-use planning, and sustainability and resilience assessment. Our final goal is to integrate both biophysical and social processes to produce a functional characterization and mapping of social-ecological systems at the regional scale and landscape level.

Please, feel free to visit the webpage of the E\&SEFT Project: "Ecosystem \& Socio-Ecosystem Functional Types: integrating biophysical and social functions to characterize and map the ecosystems of the Anthropocene" (http://functionalty.pes.caescg.org/) to know more about project goals, scientists involved, and other partners. In this webpage you can also learn more about the variables included in this survey (selection process, definitions, etc.).

*Important: if you are viewing this survey through your mobile phone, we recommend that you use it in horizontal position for better visualization.

\section{SOCIAL-ECOLOGICAL FUNCTIONING}

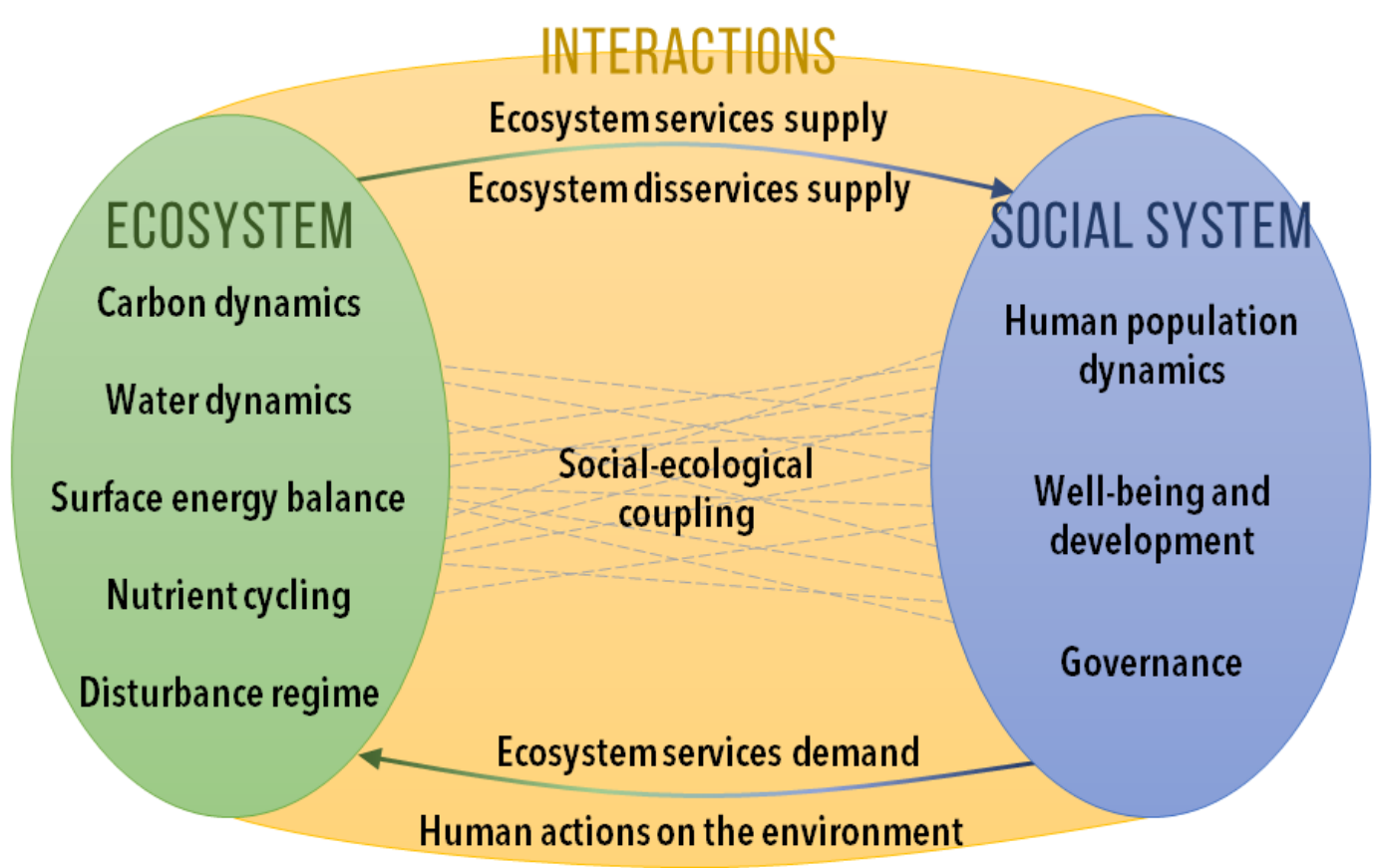

\section{Personal data (optional)}

In any case, your answers will be treated as confidential

\section{First name:}


3. Institution/Department:

4. e-mail:

5. Area of expertise:

Selecciona todos los que correspondan.

Biophysical sciences

Social sciences

Sustainability Science

Environmental management / Territorial planning

Remote sensing

Biodiversity Science

Otro:

6. Tick if you want to be acknowledged in derived publications: Selecciona todos los que correspondan.

Yes, include my name in the acknowledgments

7. Tick if you want to receive the results of this study:

Selecciona todos los que correspondan.

Yes, send to me the results of this study

\section{COMPONENT 1. SOCIAL SYSTEM}

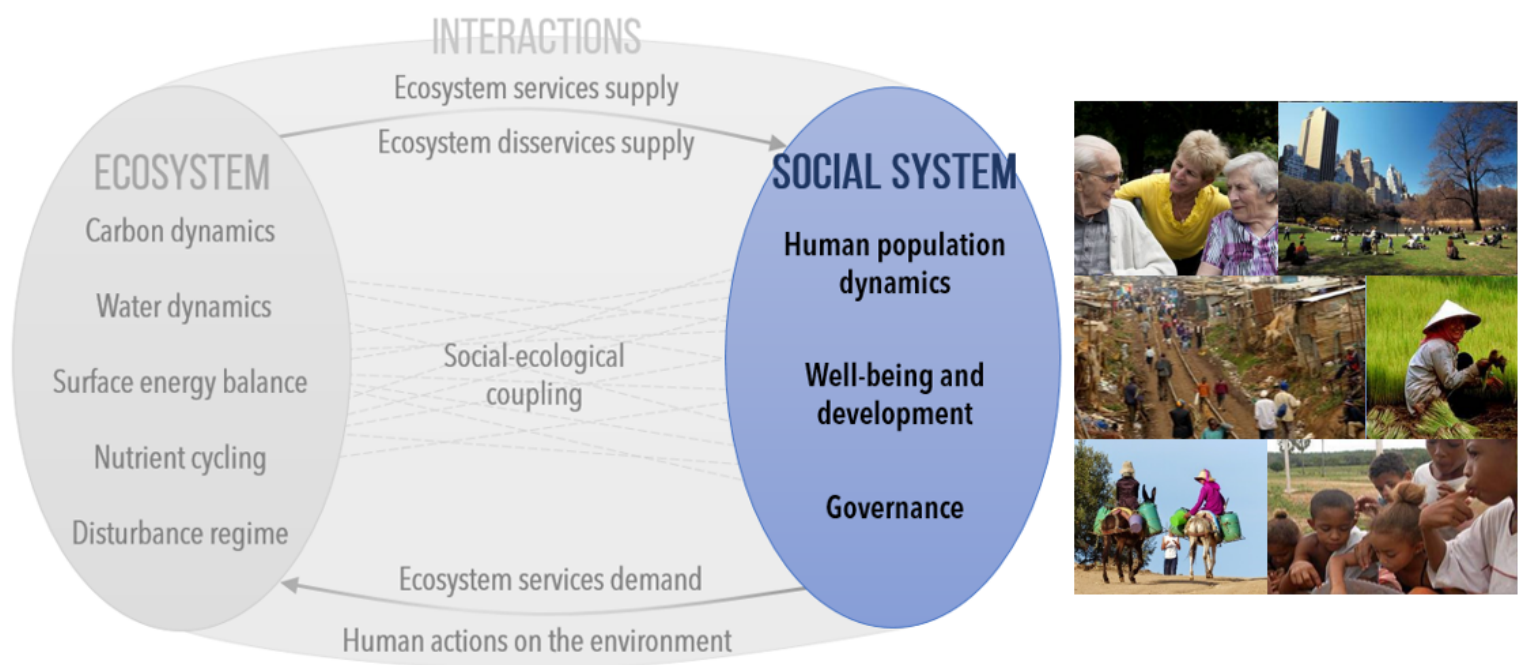

\section{Dimension 1a. Human population dynamics}


8. In your opinion, which variables that describe human population dynamics are essential to characterize social-ecological systems functioning?

Please, punctuate each variable according to its relevance for being considered as 'Essential Social-Ecological Functional Variable' (from 1 "less essential" to 5 "more essential") Marca solo un óvalo por fila.

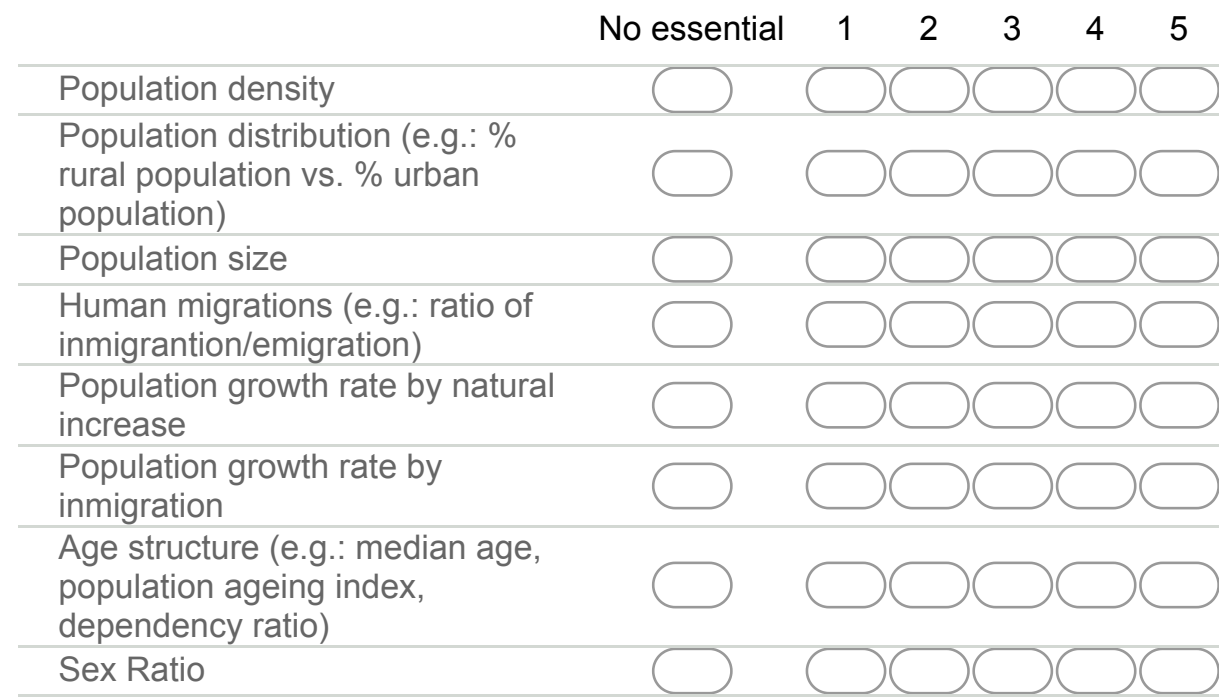

9. Would you add/modify any variable of human population dynamics to better describe social-ecological systems functioning? Please specify:

\section{Dimension 1b. Well-being and development}

(You are in: Component 1. Social System) 
10. In your opinion, which variables that describe human well-being and development are essential to characterize social-ecological systems functioning?

Please, punctuate each variable according to its relevance for being considered as 'Essential Social-Ecological Functional Variable' (from 1 "less essential" to 5 "more essential")

Marca solo un óvalo por fila.

$\begin{array}{llllll}\text { No essential } & 1 & 2 & 3 & 4 & 5\end{array}$

Access to drinking water (e.g.:

distance to drinking water)

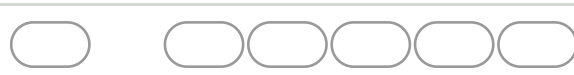

Water sanitation (e.g.: \% of

houses using improved sanitation

facilities)

Water scarcity

Electricity access

Access to internet

Educational level of the population

(e.g.: illiteracy rate, \% of

population with higher education,

school enrolment rate, out of

school rate for adolescents)

Employment (e.g.: employment

rate, unemployment rate)

Economic level of the population

(e.g.: household income, income per capita)

Poverty (e.g. \% of population with unsatisfied basic needs)

Social equality (e.g.: wealth distribution, women participation in government, women literacy rate,

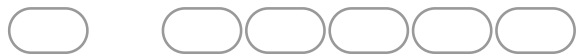
Gini Index)

Environmental quality (e.g.: air, water and soil pollution levels)

Access to healthcare and other basic social services (e.g.: \% of population receiving public

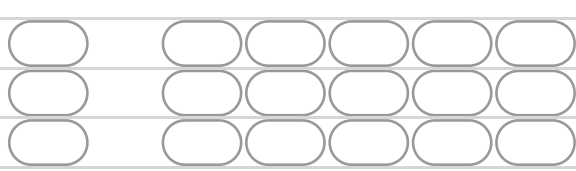
assistance)

Infant mortality rate

Life expectancy (e.g.: life

expectancy at birth)

Total fertility rate

Average household size (e.g.:

people per home)

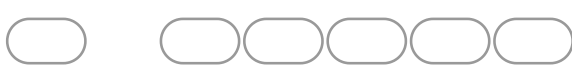

Subjective well-being (e.g.: life satisfaction)

Security (e.g.: crime rate)

Social trust (in government, institutions)

11. Would you add/modify any variable of social well-being and development to better describe social-ecological systems functioning? Please specify: 
12. In your opinion, which variables that describe regional governance are essential to characterize social-ecological systems functioning?

Please, punctuate each variable according to its relevance for being considered as 'Essential Social-Ecological Functional Variable' (from 1 "less essential" to 5 "more essential")

Marca solo un óvalo por fila.

No essential $1122 \quad 3 \quad 4 \quad 5$

Institutional diversity (degree of polycentrism and nesting level in government, with efficient horizontal and vertical coordination)

Agenda effectiveness (degree in which the agenda is adequately formulated and assessed to achieve specific goals and have a popular understanding) Stakeholders participation in decision making (degree of stakeholders inclusiveness, with an adequate leadership arrangement and commitment to group and purpose)

Internal capacity (degree of sufficiency of resources -money, information and expertise, authority and legitimacy- to

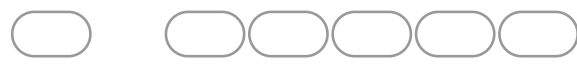
achieve success on a specific goal)

External capacity (skills and reach of the government to connect to at both the national and international levels- and secure external resources to support regional goals)

Implementation experience (level of experience addressing regional goals and degree of institutionalization of these experience in policies and processes)

Political stability

Corruption level

Current conflicts (e.g.: armed conflicts, political violence)
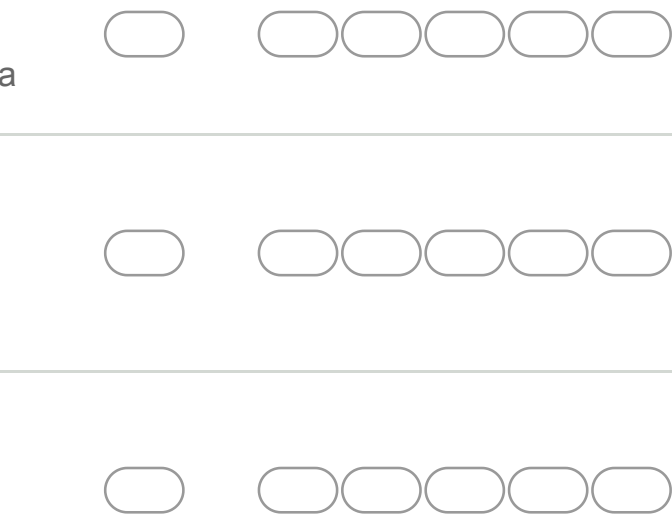


\section{COMPONENT 2. ECOSYSTEM}

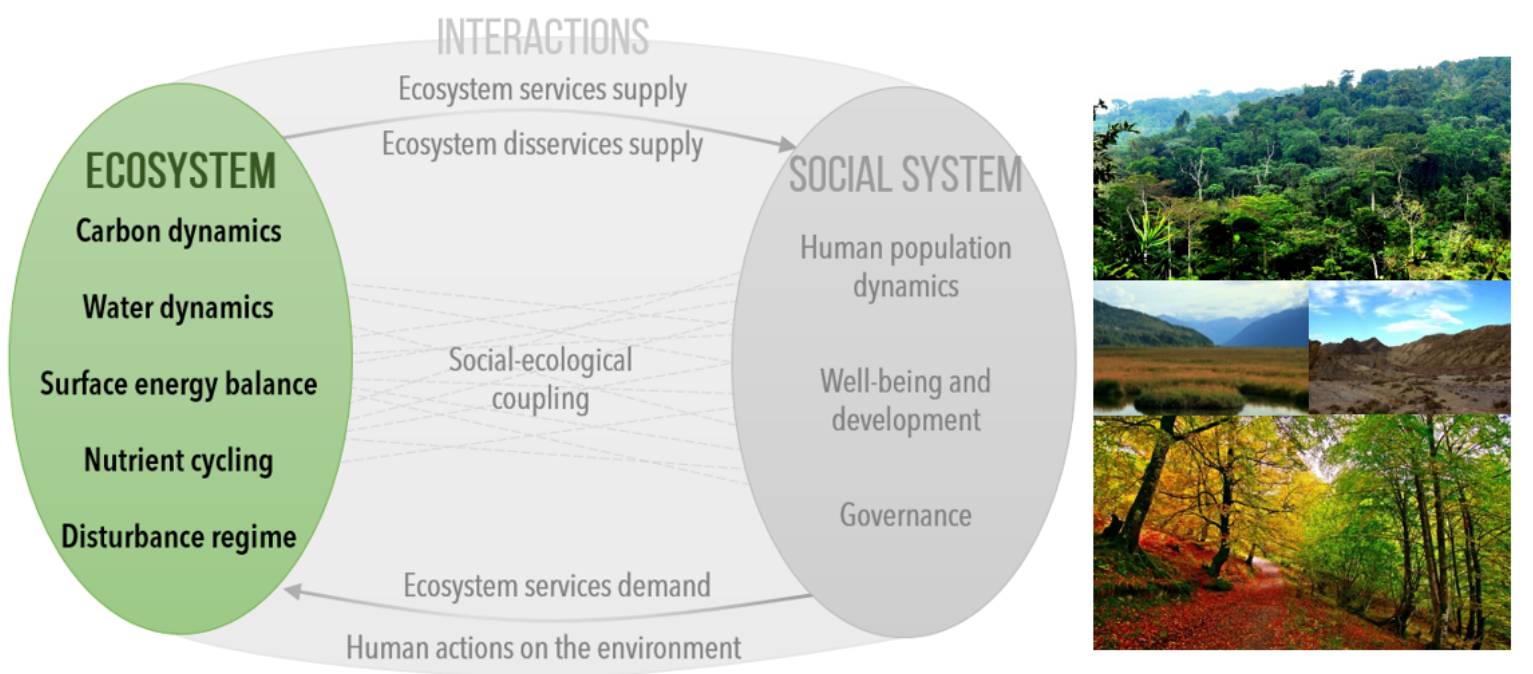

\section{Dimension 2a. Carbon dynamics}

(You are in: Component 2. Ecosystem)

14. In your opinion, which variables that describe carbon dynamics are essential to characterize social-ecological systems functioning?

Please, punctuate this variable according to its relevance for being considered as 'Essential Social-Ecological Functional Variable' (from 1 "less essential" to 5 "more essential")

Marca solo un óvalo por fila.

No essential $1 \quad 2 \quad 2 \quad 3 \quad 4 \quad 5$

Gross Primary Productivity (total
amount of carbon fixed in the
photosynthesis by plants in an
ecosystem)
Net Primary Productivity (net
productivity of organic carbon by
plants in an ecosystem, e.g.: Net
Ecosystem Exchange, Net Carbon
Flux, carbon acumulation rate)
Respiration (natural carbon
dioxide emissions by ecosystems)
Secondary productivity
(represents the formation of living
mass of a heterotrophic population
or group of populations)
Organic Carbon Storage (biomass
+ litter + soil organic carbon)
Radiation Use Efficiency (organic
carbon produced by unit of
absorbed solar radiation)
Ecosystem composition by Plant
Functional Types (plant
classification according to their
physical, phylogenetic and
phenological characteristics)


15. Would you add/modify any variable of carbon dynamics to better describe socialecological systems functioning? Please specify:

\section{Dimension 2b. Water dynamics}

(You are in: Component 2. Ecosystem)

16. In your opinion, which variables that describe water dynamics are essential to characterize social-ecological systems functioning?

Please, punctuate this variable according to its relevance for being considered as 'Essential Social-Ecological Functional Variable' (from 1 "less essential" to 5 "more essential")

Marca solo un óvalo por fila.

Precipitation (water + snow)
Snow precipitations
Howizontal precipitation (e.g.: fog,
dew, frost)
Extra-precipitation water
contributions (e.g.: surface or
groundwater inputs by rivers or
Potential evapotranspiration
Actual evapotranspiration
Potencial water deficit -or excess-
Actual water deficit -or excess-
(due to climatic and
ecohydrological conditions)
Evaporation - Transpiration ratio
Soil water infiltration capacity
Deep drainage (to aquifers)
Groundwater depth
Actual Soil Water Storage
Total water yield or "blue water"
(runoff + deep drainage)
Flows of green water (water in and
on soils and on vegetation
canopy)
Precipitation Use Efficiency
(organic carbon produced by unit
of precipitation or by unit of
evapotranspiration)
Vegetation water stress (e.g.
precipitation minus [potential or
actual] evapotranspiration)


17. Would you add/modify any variable of water dynamics to better describe social-ecological systems functioning? Please specify:

\section{Dimension 2c. Surface energy balance}

(You are in: Component 2. Ecosystem)

18. In your opinion, which variables that describe surface energy balance are essential to characterize social-ecological systems functioning?

Please, punctuate each variable according to its relevance for being considered as 'Essential Social-Ecological Functional Variable' (from 1 "less essential" to 5 "more essential")

Marca solo un óvalo por fila.

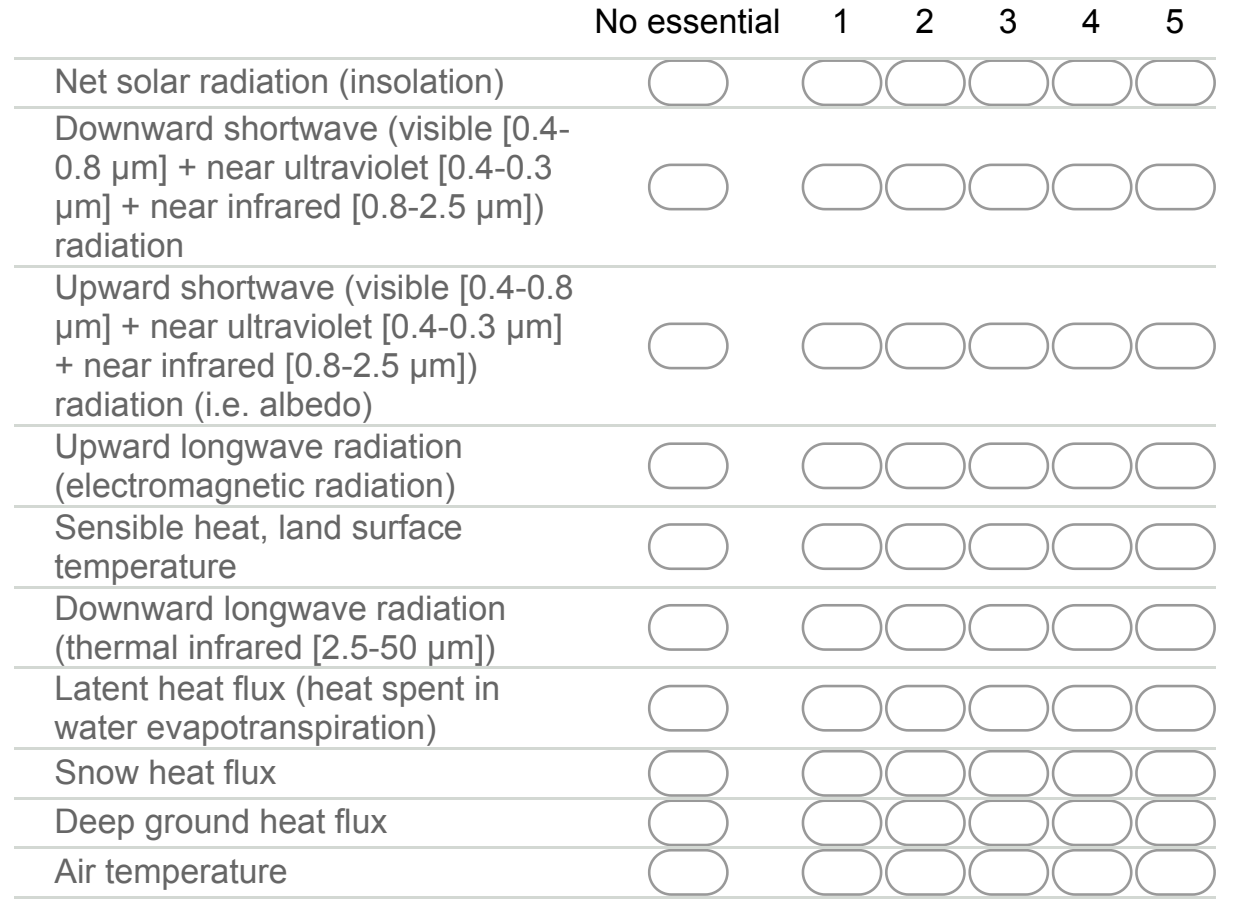

19. Would you add/modify any variable of surface energy balance to better describe socialecological systems functioning? Please specify:

\section{Dimension 2d. Nutrient cycling}

(You are in: Component 2. Ecosystem) 
20. In your opinion, which variables that describe nutrient cycling are essential to characterize social-ecological systems functioning?

Please, punctuate each variable according to its relevance for being considered as 'Essential Social-Ecological Functional Variable' (from 1 "less essential" to 5 "more essential")

Marca solo un óvalo por fila.

No essential $1 \quad 2 \quad 2 \quad 3 \quad 4 \quad 5$

Nitrogen fixation (atmospheric

nitrogen fixed by $\mathrm{N}$-fixer

organisms, e.g.: Rhizobium)

Nitrogen deposition (wet and dry

deposition of ammonium, nitrate,

and particulate nitrogen)

Phosphorus deposition (e.g.:

aerosols and atmospheric dust,

etc.)

Gross nitrogen mineralization

(e.g.: rate of production of

ammonium in soils)

Net nitrogen mineralization (e.g.:

net rate of production of plant-

available nitrogen)

Soil phosphorus availability (e.g.:

concentrations of non-occluded

soil phosphorus)

Nitrogen status of plants (e.g.:

plant tissue nitrogen

concentrations)

Phosphorus status of plants (e.g.:

plant tissue phosphorus

concentrations)

No essential $1-2 \quad \begin{array}{llll}2 & 3 & 4 & 5\end{array}$

21. Would you add/modify any variable of nutrient cycling to better describe social-ecological systems functioning? Please specify:

\section{Dimension 2e. Disturbance regime}

(You are in: Component 2. Ecosystem) 
22. In your opinion, which variables that describe disturance regime are essential to characterize social-ecological systems functioning?

Please, punctuate each variable according to its relevance for being considered as 'Essential Social-Ecological Functional Variable' (from 1 "less essential" to 5 "more essential")

Marca solo un óvalo por fila.

No essential $1 \quad 2 \quad 2 \quad 3 \quad 4 \quad 5$

Drought occurrence [frequency,

severity, extension]

Fire occurrence [frequency,

severity, extension]

Flood occurrence [frequency,

severity, extension]

Herbivory (natural, not cattle

grazing) [frequency, severity,

extension]

Pest outbreaks occurrence

[frequency, severity, extension]

Hurricanes/ storms occurence

[frequency, severity, extension]

Landslides occurrence [frequency,

severity, extension]

Volcanic eruptions occurrence

[frequency, severity, extension]

23. Would you add/modify any variable of disturbance regime to better describe socialecological systems functioning? Please specify:

\section{COMPONENT 3. INTERACTIONS}

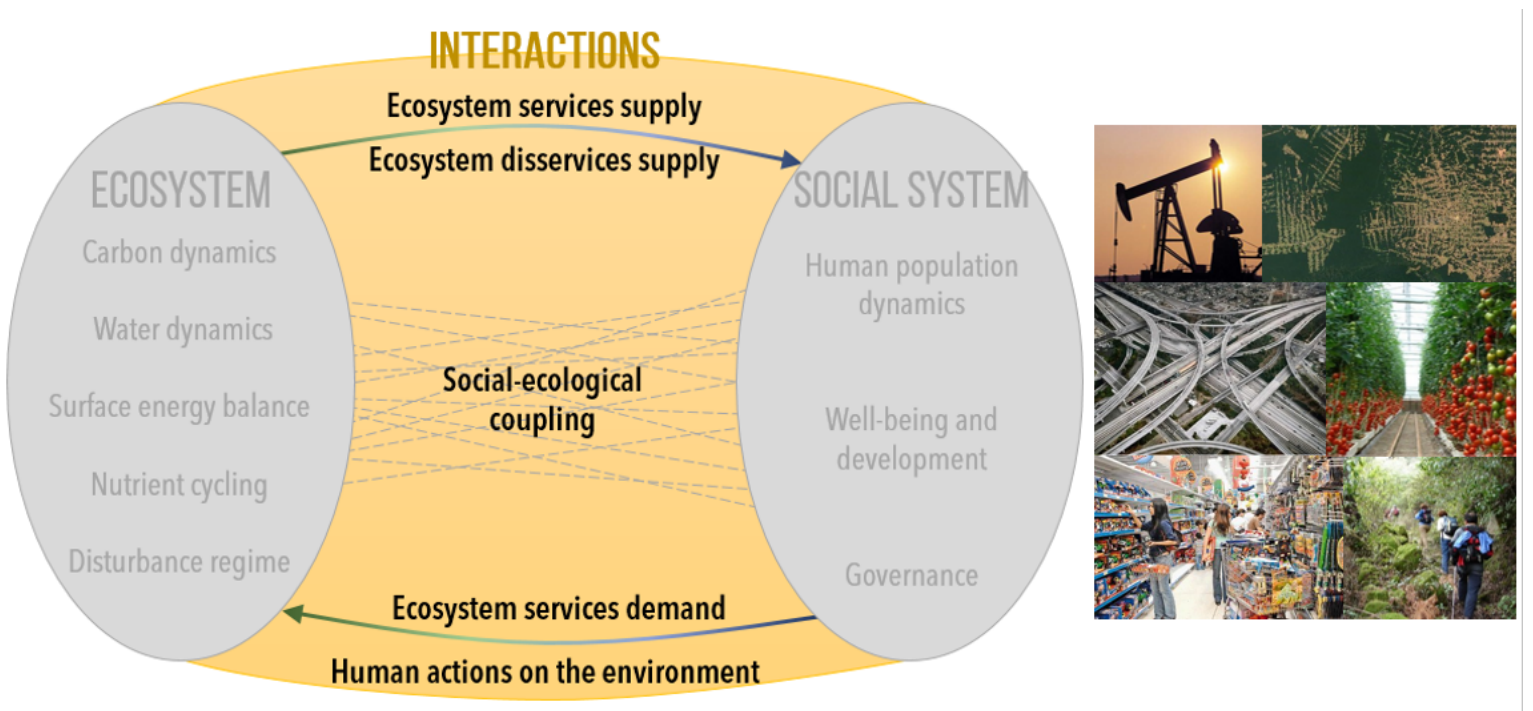

\section{Dimension 3a. Ecosystem services supply}

(You are in: Component 3. Interactions) 
24. In your opinion, which variables that describe provisioning services supply are essential to characterize social-ecological systems functioning?

Please, punctuate each variable according to its relevance for being considered as 'Essential Social-Ecological Functional Variable' (from 1 "less essential" to 5 "more essential")

Marca solo un óvalo por fila.

Agricultural production
Sivestock production
for drinking
Surface and ground water sources
Bioman-drinking purposes
Fibres and other manterials from
direct use or processing
Wild plants, algae and their
outputs for food
Wild animals and their outputs for
food

25. In your opinion, which variables that describe regulation \& maintenance services supply are essential to characterize social-ecological systems functioning?

Please, punctuate each variable according to its relevance for being considered as 'Essential Social-Ecological Functional Variable' (from 1 "less essential" to 5 "more essential")

Marca solo un óvalo por fila.

Hydrological cycle and water flow
maintenance
Local climate regulation
Pollination and seed dispersal
Best and disease control
Chemical conediation
Mass freshwaters and salt waters
erosion rates
Ventilation (air renewalion and control of

26. In your opinion, which variables that describe cultural services supply are essential to characterize social-ecological systems functioning?

Please, punctuate each variable according to its relevance for being considered as 'Essential Social-Ecological Functional Variable' (from 1 "less essential" to 5 "more essential")

Marca solo un óvalo por fila.

No essential $1122 \quad 3 \quad 4 \quad 5$

Physical and experiential interactions (with plants, animals, landscapes, seascapes)

Intellectual and representative interacions (scientific, educational, heritage and cultural, entertainment, aesthetic contemplation)

Spiritual and/or emblematic

(symbolic, sacred and/or religious) interactions 
This candidate variables have been adapted from the Common International Classification of Ecosystem Services (CICES) 4.3 version ('class' level of this classification for provisioning and regulating services, and 'group' level for cultural services) (European Environment Agency, 2013).

\section{Would you add/modify any variable of ecosystem services supply to better describe social-ecological systems functioning? Please specify:}

\section{Dimension 3b. Ecosystem disservices supply}

(You are in: Component 3. Interactions)

\section{In your opinion, which variables that describe ecosystem disservices supply are essential} to characterize social-ecological systems functioning?

Please, punctuate each variable according to its relevance for being considered as 'Essential Social-Ecological Functional Variable' (from 1 "less essential" to 5 "more essential")

Marca solo un óvalo por fila.

$\begin{array}{llllll}\text { No essential } & 1 & 2 & 3 & 4 & 5\end{array}$

Bio-economic (e.g.: biological invasions, agricultural and fisheries pests and diseases incidence, red tydes)

Abiotic-economic (e.g.: droughts and fires occurrence, siltation, leaching of nutrients)

Bio-health (e.g.: human diseases incidence from pathogens, allergens)

Abiotic-health (e.g.: flood and storm events occurrence ) Bio-cultural (e.g.: bird droppings on outdoor sculptures, tree roots cracking pavements)

Abiotic-cultural (e.g.: soil erosion rates, mud/landslide scar events, unpleasant odours from rotting organic matter)

It is noted that this candidate variables express the incidence of different kinds of harmful events. For simplicity, they have been classified according to their origin and primary dimension of human wellbeing affected, following Shackleton et al. (2016) approach. 
29. Would you add/modify any variable of ecosystem disservices supply to better describe social-ecological systems functioning? Please specify:

\section{Dimension 3c. Ecosystem services demand}

(You are in: Component 3. Interactions)

30. In your opinion, which variables that describe the human capture of ecosystem goods and services are essential to characterize social-ecological systems functioning?

Please, punctuate each variable according to its relevance for being considered as 'Essential Social-Ecological Functional Variable' (from 1 "less essential" to 5 "more essential") Marca solo un óvalo por fila.

Water use level (e.g.: water
consumed per capita/ per year)
Water use for irrigated agriculture
(e.g.: water use per hectare/ per
year)
Energy use level (e.g.: energy
consumed per capita/ per year)
Material use level (e.g.: raw
materials consumed per capita/
per year)
Human Appropriation of Net
Primary Production (e.g.: Tn $\mathrm{C}$
extracted/ per hectare/ per year)
$\begin{aligned} & \text { Appropriation of land for } \\ & \text { agriculture } \\ & \text { Nature tourism (e.g.: number of } \\ & \text { visitors to natural areas) }\end{aligned}$

31. Would you add/modify any variable of ecosystem services demand to better describe social-ecological systems functioning? Please specify:

\section{Dimension 3d. Human actions on the environment}

(You are in: Component 3. Interactions) 
32. In your opinion, which variables that describe the human actions on the environment are essential to characterize social-ecological systems functioning?

Please, punctuate each variable according to its relevance for being considered as 'Essential Social-Ecological Functional Variable' (from 1 "less essential" to 5 "more essential")

Marca solo un óvalo por fila.

No essential $1 \quad 2 \quad 2 \quad 3 \quad 4 \quad 5$

Land cover/Land use change

(e.g.: agriculturization, urbanisation, land abandonment)

Land use intensity

Territorial connectivity (e.g.

distance to main roads, travel time

to major cities)

Anthropogenic water management

(e.g.: water delivery, drainage and storage systems)

Anthropogenic carbon dioxide emissions (e.g.: per capita $\mathrm{CO} 2$ emissions, $\mathrm{CO} 2$ emissions by sector of economic activity)

Net carbon dioxide flux (e.g.: CO2

emissions - CO2 sequestration)

Pollution (toxic emissions and spills)

Eutrofization of water bodies Soil erosion (by anthropogenic practices)

Conservation tillage (sustainable agricultural practices for soil preservation)

Ecological restoration

Land protection (e.g.: \% of the territory declared as natural protected area with a management plan)

33. Would you add/modify any variable of human actions on the environment to better describe social-ecological systems functioning? Please specify:

\section{Dimension 3e. Social-ecological coupling}

(You are in: Component 3. Interactions) 
34. In your opinion, which variables that describe the degree of connection of a community to its local environment are essential to characterize social-ecological systems functioning?

Please, punctuate each variable according to its relevance for being considered as 'Essential Social-Ecological Functional Variable' (from 1 "less essential" to 5 "more essential") Marca solo un óvalo por fila.

\section{No essential $1122 \quad 3 \quad 4 \quad 5$}

Local natural capital dependence

(e.g.: \% of final ecosystem services consumed by the population that are provided

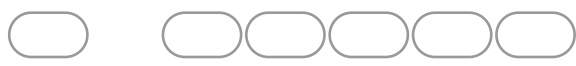
directly by local environment) Import [export] rates of agricultural and livestock products

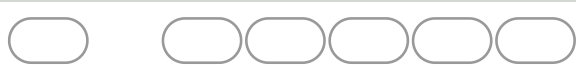

Weight in the economy of the non-

ecosystem services market

(goods and services that do not come directly from ecosystems, e.g.: socioeconomic services like hospitals, schools or culture, internet, manufactured products, technology)

Airports [ports] activity

Dependence on fossil energies

(e.g.: \% of energy consumed

coming from fossil resources)

Renewable energy use (e.g.: \% of energy consumed coming from renewable sources)

Weight of sectors in the economy (agriculture vs. industry vs. services)

Weight of traditional (vs. intensive) agricultural and livestock sector in the economy

Population employed by sectors (agriculture vs. industry vs.

services)

Population employed in traditional (vs. intensive) agriculture and stockbreeding

Biocapacity (capacity of ecosystems to meet people's local demand and assimilate waste products)

Land tenure (e.g.: \% communal lands vs. private lands vs. government lands)

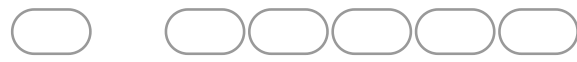

Access to natural or seminatural areas (e.g.: distance to a natural or seminatural area)

Human perception of ecosystem services (awareness level of the population about services provided by local ecosystems) Human population ethnicity (e.g.: $\%$ of indigenous population) Cultural attachment to nature

Local green initiatives (e.g.: in agriculture, cities, touristic activities, local companies)
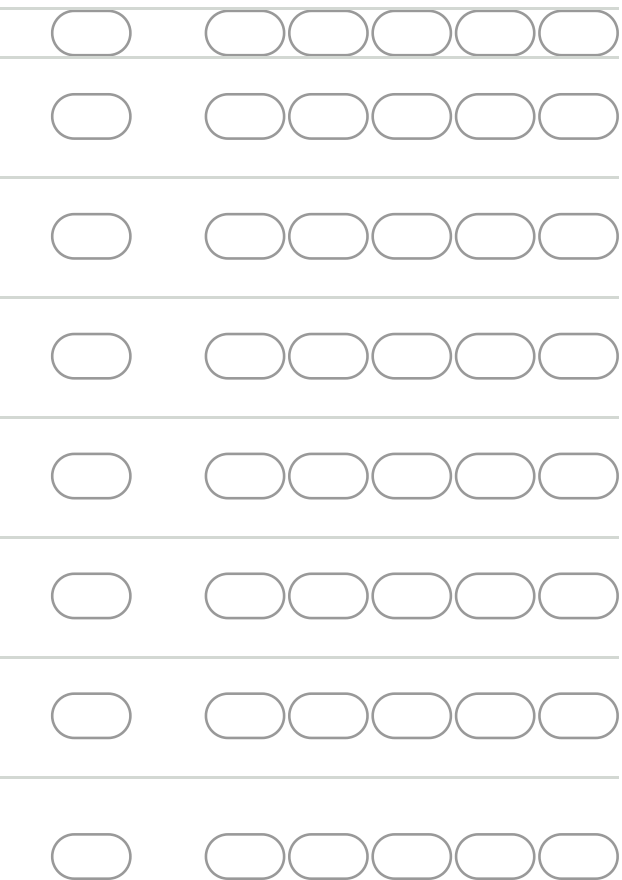


\section{No essential $11 \quad 2 \quad 3 \quad 4 \quad 4 \quad 5$}

Non-ecosystem services demand (goods and services that do not come directly from ecosystems, e.g.: socioeconomic services like hospitals, schools or culture, internet, manufactured products, technology)

35. Would you add/modify any variable of social-ecological coupling to better describe socialecological systems functioning? Please specify: 
Appendix 5. Tables

Table A5.1. Preliminary and enhanced lists of variables for characterizing and monitoring SESs, structured into dimensions across the three components of a SES. The preliminary list contains 77 variables structured into 12 dimensions and was generated through literature review and an initial expert workshop. The improved list contains 149 variables structured into 13 dimensions and was the result of analyzing the preliminary survey results (56 responses) in a second scientific workshop. This improved list was then introduced in the final survey with the aim of using scientist scorings to prioritize the variables.

\begin{tabular}{|c|c|c|c|}
\hline Component & Dimension & $\begin{array}{l}\text { Preliminary list ( } 77 \text { variables } \\
\text { in } 12 \text { dimensions) }\end{array}$ & $\begin{array}{l}\text { Improved list (149 variables } \\
\text { in } 13 \text { dimensions) }\end{array}$ \\
\hline \multirow[t]{21}{*}{ Social system } & \multirow{8}{*}{$\begin{array}{l}\text { Human population } \\
\text { dynamics }\end{array}$} & Population density & Population density \\
\hline & & Population distribution & Population distribution \\
\hline & & Population size & Population size \\
\hline & & Human migrations & Human migrations \\
\hline & & Age structure & Age structure \\
\hline & & Sex Ratio & Sex Ratio \\
\hline & & & $\begin{array}{l}\text { Population growth rate by } \\
\text { natural increase }\end{array}$ \\
\hline & & & $\begin{array}{l}\text { Population growth rate by } \\
\text { immigration }\end{array}$ \\
\hline & \multirow{13}{*}{$\begin{array}{l}\text { Wellbeing and } \\
\text { development }\end{array}$} & Access to drinking water & Access to drinking water \\
\hline & & Water sanitation & Water sanitation \\
\hline & & Electricity access & Electricity access \\
\hline & & Access to internet & Access to internet \\
\hline & & $\begin{array}{l}\text { Educational level of the } \\
\text { population }\end{array}$ & $\begin{array}{l}\text { Educational level of the } \\
\text { population }\end{array}$ \\
\hline & & Employment & Employment \\
\hline & & $\begin{array}{l}\text { Economic level of the } \\
\text { population }\end{array}$ & $\begin{array}{l}\text { Economic level of the } \\
\text { population }\end{array}$ \\
\hline & & Social equity & Social equity \\
\hline & & Environmental quality & Environmental quality \\
\hline & & Mortality & Infant mortality rate \\
\hline & & Overcrowding & Average household size \\
\hline & & Life expectancy & Life expectancy \\
\hline & & Institutional diversity & - \\
\hline
\end{tabular}




\begin{tabular}{|c|c|c|c|}
\hline & & Land protection & - \\
\hline & & & Water scarcity \\
\hline & & & Poverty \\
\hline & & & $\begin{array}{l}\text { Access to healthcare and } \\
\text { other basic social services }\end{array}$ \\
\hline & & & Total fertility rate \\
\hline & & & Subjective wellbeing \\
\hline & & & Security \\
\hline & & & Social trust \\
\hline & Governance (not & & Institutional diversity \\
\hline & included in $1^{\text {st }}$ survey) & & Agenda effectiveness ${ }^{1}$ \\
\hline & & & $\begin{array}{l}\text { Stakeholders participation } \\
\text { in decision making }\end{array}$ \\
\hline & & & Internal capacity ${ }^{1}$ \\
\hline & & & External capacity ${ }^{1}$ \\
\hline & & & Implementation experience $^{1}$ \\
\hline & & & Political stability \\
\hline & & & Corruption level \\
\hline & & & Current conflicts \\
\hline Ecological & Organic carbon & Net Primary Productivity & Net Primary Productivity \\
\hline & dynamics & & Gross Primary Productivity \\
\hline & $\begin{array}{l}\text { (Carbon dynamics in } 1^{\text {st }} \\
\text { survev) }\end{array}$ & & Respiration \\
\hline & & & Secondary productivity \\
\hline & & & Organic carbon storage \\
\hline & & & Radiation Use Efficiency \\
\hline & & & $\begin{array}{l}\text { Ecosystem composition by } \\
\text { Plant Functional Types }\end{array}$ \\
\hline & Water dynamics & Evapotranspiration & Actual evapotranspiration \\
\hline & & & Potential evapotranspiration \\
\hline & & & Precipitation \\
\hline & & & Snow precipitations \\
\hline & & & Snow storage \\
\hline & & & Horizontal precipitation \\
\hline & & & $\begin{array}{l}\text { Extra-precipitation water } \\
\text { contributions }\end{array}$ \\
\hline & & & $\begin{array}{l}\text { Potential water deficit -or } \\
\text { excess- }\end{array}$ \\
\hline
\end{tabular}


Actual water deficit -or excess-

Evaporation - Transpiration ratio

Soil water infiltration capacity

Deep drainage

Groundwater depth

Actual Soil Water Storage

Total water yield or "blue water"

Flows of green water

Precipitation Use Efficiency

Vegetation water stress

Surface energy balance (Energy dynamics in $1^{\text {st }}$ survey)

Nutrient cycling

Disturbance regime
Land surface energy balance

Albedo

Land surface temperature
Upward shortwave radiation Sensible heat, land surface temperature

Net solar radiation

Downward shortwave radiation

Upward longwave radiation Downward longwave radiation

Latent heat flux

Snow heat flux

Deep ground heat flux

Air temperature

Nitrogen cycling

Phosphorus cycling

Nitrogen fixation

Nitrogen deposition

Phosphorus deposition

Gross nitrogen mineralization

Net nitrogen mineralization Soil phosphorus availability Nitrogen status of plants

Phosphorus status of plants Drought occurrence 
Fire occurrence

Interactions
Ecosystem service supply $^{2} \dagger$
Cropland production (P)

Livestock production (P)

Surface and groundwater sources for drinking $(\mathrm{P})$

Surface and ground water sources for nondrinking purposes $(\mathrm{P})$

Biomass-based energy sources $(\mathrm{P})$

Fibres and other materials from plants, algae and animals for direct use or processing $(\mathrm{P})$

Wild plants, algae and their outputs for food (P)

Wild animals and their outputs for food (P)

Hydrological cycle and water flow maintenance (R)

Global climate regulation (R)

Pollination and seed dispersal (R)

Pest and disease control (R)

Bioremediation (R)

Chemical conditions maintenance of freshwaters and salt waters (R)

Mass stabilisation and control of erosion rates (R)

Ventilation and transpiration (R)
Fire occurrence

Flood occurrence

Herbivory

Pest outbreaks occurrence

Hurricanes/storms occurrence

Landslides occurrence

Volcanic eruptions occurrence

Cropland production (P)

Livestock production (P)

Surface and groundwater sources for drinking $(\mathrm{P})$

Surface and ground water sources for nondrinking purposes $(\mathrm{P})$

Biomass-based energy sources (P)

Fibres and other materials from plants, algae and animals for direct use or processing $(\mathrm{P})$

Wild plants, algae and their outputs for food (P)

Wild animals and their outputs for food (P)

Hydrological cycle and water flow maintenance (R)

Local climate regulation (R)

Pollination and seed dispersal (R)

Pest and disease control (R)

Bioremediation (R)

Chemical conditions maintenance of freshwaters and salt waters (R)

Mass stabilisation and control of erosion rates $(\mathrm{R})$

Ventilation (R) 
Weathering, decomposition and fixing rates (for soil formation) (R)

Physical and experiential interactions (C)

Intellectual and representative interacions (C)

Spiritual and/or emblematic interactions (C)

Bio-economic

Abiotic-economic

Bio-health

Abiotic-health

Bio-cultural

Abiotic-cultural

Water use level

Energy use level

Material use level

Human Appropriation of Net Primary Production

Ecosystem service demand

Human actions on the
environment

Land use intensity

Isolation

Carbon dioxide emissions

Pollution
Physical and experiential interactions (C)

Intellectual and representative interacions (C)

Spiritual and/or emblematic interactions (C)

Bio-economic

Abiotic-economic

Bio-health

Abiotic-health

Bio-cultural

Abiotic-cultural

Water use level

Energy use level

Material use level

Human Appropriation of Net Primary Production

Water use for irrigated crops

Appropriation of land for agriculture

Nature tourism

Land use intensity

Territorial connectivity

Anthropogenic carbon dioxide emissions

Pollution

Land cover/Land use change

Anthropogenic water management

Net carbon dioxide flux

Eutrophication of water bodies

Soil erosion

Conservation tillage

Ecological restoration

Land protection 
Social-ecological
coupling
Local natural capital

dependence

Import [export] rates

Weight in the economy of the non-ecosystem services market

Airports [ports] activity

Dependence on fossil energies

Renewable energy use

Weight of farming [industry, services] sector in the economy

Population employed in farming [industry, services] sectors

Land tenure structure

Access to natural or semi natural areas

Human perception of ecosystem services

Human population ethnicity

Local green initiatives

Non-ecosystem services demand
Local natural capital dependence

Import [export] rates of crop and livestock products

Weight in the economy of the non-ecosystem services market

Airports [ports] activity

Dependence on fossil energies

Renewable energy use

Weight of sectors in the economy

Population employed by sectors

Land tenure

Access to natural or seminatural areas

Human perception of ecosystem services

Human population ethnicity

Local green initiatives

Non-ecosystem services demand

Weight of traditional (vs. intensive) agricultural sector in the economy

Population employed in traditional (vs. intensive) agriculture

Biocapacity

Cultural attachment to nature

† $\mathrm{P}$ = provisioning services; $\mathrm{R}$ = regulating services; $\mathrm{C}=$ cultural services

${ }^{1}$ Foster, K. A., and W. R. Barnes. 2012. Reframing Regional Governance for Research and Practice. Urban Affairs Review 48(2):272-283.

${ }^{2}$ Haines-Young, R., and M. Potschin. 2013. Common International Classification of Ecosystem Services (CICES): Consultation on Version 4, August-December 2012. [online] URL: https://www.cices.eu 
${ }^{3}$ Shackleton, C. M., S. Ruwanza, G. K. Sinasson Sanni, S. Bennett, P. De Lacy, R. Modipa, N. Mtati, M. Sachikonye, and G. Thondhlana. 2016. Unpacking Pandora's Box: Understanding and Categorising Ecosystem Disservices for Environmental Management and Human Wellbeing. Ecosystems 19(4):587-600. [online] URL: https://doi.org/10.1007/s10021-015-9952-z 
Table A5.2. List of prioritized variables for characterizing and monitoring SES (extended version with examples and explanations). The list is structured into 13 dimensions across the three components of a SES (Fig. 2 in the paper). Priority level 1 (top priority) includes variables with relevance and consensus above the $90^{\text {th }}$ percentile; level 2 includes variables between the $75^{\text {th }}$ and $90^{\text {th }}$ percentiles; level 3 includes variables with relevance above the $75^{\text {th }}$ percentile but consensus between the $50^{\text {th }}$ and $75^{\text {th }}$ percentiles and vice versa; and finally, level 4 includes variables with relevance and consensus between the $50^{\text {th }}$ and $75^{\text {th }}$ percentiles. The nonpriority category includes variables with relevance and consensus below the $50^{\text {th }}$ percentile.

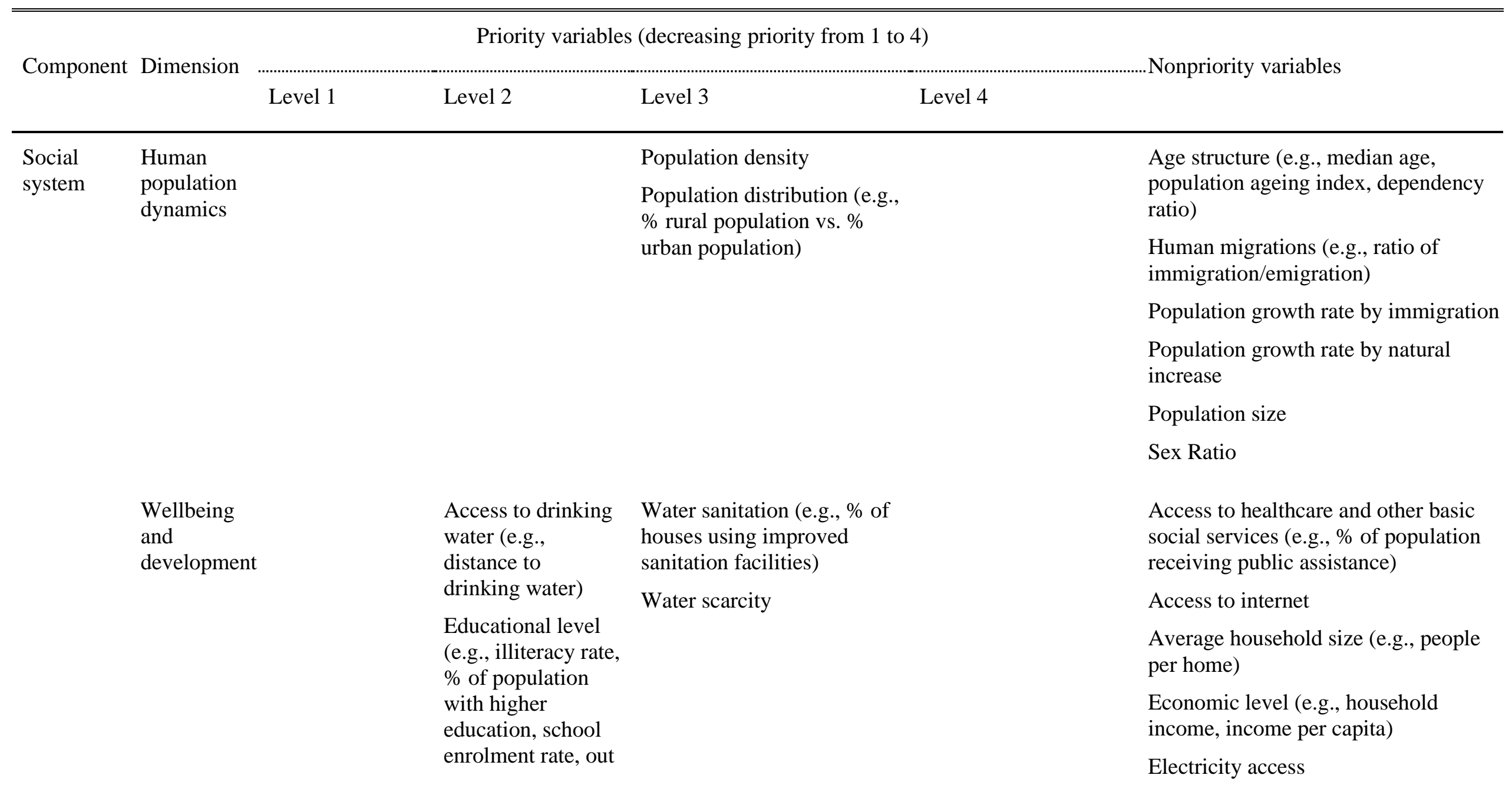


of school rate for adolescents)

\section{Environmental}

quality (e.g., air,

water and soil

pollution levels)

Poverty (e.g., \% of

population with

unsatisfied basic

needs)

Social equity (e.g.,

wealth distribution,

women

participation in

government,

women literacy

rate, Gini Index)

Governance
Current conflicts

(e.g., armed

conflicts, political

violence)
Employment (e.g., employment rate, unemployment rate)

Infant mortality rate

Life expectancy (e.g., life expectancy at birth)

Security (e.g., crime rate)

Social trust (in government, institutions)

Subjective wellbeing (e.g., life satisfaction)

Total fertility rate
Political stability
Corruption level

Agenda effectiveness (degree in which the agenda is adequately formulated and assessed to achieve specific goals and have a popular understanding) ${ }^{1}$

External capacity (skills and reach of the government to connect to - at both the national and international levelsand secure external resources to support regional goals)

Implementation experience (level of experience addressing regional goals and degree of institutionalization of these experience in policies and processes)

Institutional diversity (degree of polycentrism and nesting level in 


\section{Ecological Organic \\ system carbon}

dynamics

Water

Precipitation

(water + snow)
Net primary productivity (net productivity of organic carbon by plants in an ecosystem, e.g., Net

Ecosystem Exchange, Net Carbon Flux, carbon accumulation rate)

Organic carbon storage (biomass + litter + soil organic carbon)

Actual evapotranspiration

Actual water deficit -or excess- (due to climatic and ecohydrological conditions) government, with efficient horizontal and vertical coordination)

Internal capacity (degree of sufficiency of resources -money, information and expertise, authority and legitimacy- to achieve success on a specific goal)

Stakeholders participation in decision making (degree of stakeholder's inclusiveness, with an adequate leadership arrangement and commitment to group and purpose)

Ecosystem composition Gross Primary Productivity (total by plant functional type amount of carbon fixed in the (plant classification photosynthesis by plants in an according to their ecosystem)

physical, phylogenetic and phenological characteristics)

Radiation Use Efficiency (organic carbon produced by unit of absorbed solar radiation)

Respiration (natural carbon dioxide emissions by ecosystems)

Secondary productivity (represents the formation of living mass of a heterotrophic population or group of populations)

Soil water infiltration Actual Soil Water Storage capacity

Deep drainage (to aquifers)

Extra-precipitation water contributions (e.g., surface or groundwater inputs by rivers or aquifers, respectively) 
Evaporation - Transpiration ratio

Flows of green water (water in and on soils and on vegetation canopy)

Groundwater depth

Horizontal precipitation (e.g., fog, dew, frost)

Potential evapotranspiration

Potential water deficit -or excess- (due to climate conditions)

Precipitation Use Efficiency (organic carbon produced by unit of precipitation or by unit of evapotranspiration)

Snow precipitations

Snow storage

Total water yield or "blue water" (runoff + deep drainage)

Vegetation water stress (e.g., precipitation minus [potential or actual] evapotranspiration) 
Surface

energy

balance

\section{Net solar radiation}

(insolation)

\section{Nutrient Nitrogen \\ cycling fixation \\ (atmospheric \\ nitrogen fixed \\ by $\mathrm{N}$-fixer \\ organisms, e.g., \\ Rhizobium)}

Land surface

temperature (sensitive

heat)

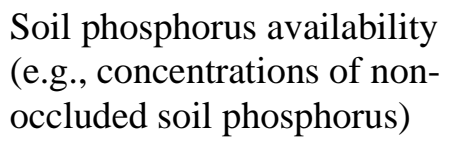

Nitrogen deposition of ammonium, nitrate and particulate nitrogen) evapotranspiration)
Gross nitrogen mineralization (e.g.,

Air temperature

Deep ground heat flux

Downward longwave radiation (thermal infrared [2.5-50 $\mu \mathrm{m}]$ )

Downward shortwave radiation (visible [0.4-0.8 $\mu \mathrm{m}]+$ near ultraviolet $[0.4-0.3 \mu \mathrm{m}]+$ near infrared [0.8-2.5 $\mu \mathrm{m}])$

Latent heat flux (heat spent in water

Snow heat flux

Upward longwave radiation (electromagnetic radiation)

Upward shortwave radiation (visible [0.4-0.8 $\mu \mathrm{m}]+$ near ultraviolet [0.4-0.3 $\mu \mathrm{m}]+$ near infrared [0.8-2.5 $\mu \mathrm{m}]$ ) (i.e. albedo)

\section{soils)}

Net nitrogen mineralization (e.g., net rate of production of plant-available nitrogen)

Nitrogen status of plants (e.g., plant tissue nitrogen concentrations)

Phosphorus deposition (e.g., aerosols and atmospheric dust, etc.)

Phosphorus status of plants (e.g., plant tissue phosphorus concentrations) 


$\begin{array}{clll}\begin{array}{c}\text { Disturbance } \\ \text { regime }\end{array} & \begin{array}{l}\text { Drought } \\ \text { occurrence } \\ \text { Flood } \\ \text { occurrence }\end{array} & \text { Fire occurrence } & \begin{array}{l}\text { Hurricanes/storms } \\ \text { occurrence } \\ \text { Pest outbreaks occurrence }\end{array} \\ & \begin{array}{l}\text { Cropland } \\ \text { production (P) }\end{array} & \begin{array}{l}\text { Surface and groundwater } \\ \text { sources for nondrinking } \\ \text { purposes (P) }\end{array} \\ \begin{array}{l}\text { Ecosystem } \\ \text { service }\end{array} & \begin{array}{l}\text { Livestock } \\ \text { suppluction (P) }\end{array} & \text { Local climate regulation (R) } \\ & \begin{array}{l}\text { Surface and } \\ \text { groundwater } \\ \text { sources for } \\ \text { drinking (P) }\end{array} & \begin{array}{l}\text { Pest and disease control (R) } \\ \text { Pollination and seed } \\ \text { dispersal (R) }\end{array} \\ & \begin{array}{l}\text { Hydrological } \\ \text { cycle and water } \\ \text { flow } \\ \text { maintenance (R) }\end{array} & \\ & & \\ & & \end{array}$

Chemical conditions Biomass-based energy sources (P)

maintenance of

freshwater and

saltwater (R)

Bioremediation (R)

Fibres and other materials from plants, algae and animals for direct use or processing $(\mathrm{P})$

Intellectual and representative interactions (scientific, educational, heritage and cultural, entertainment, aesthetic contemplation) (C)

Mass stabilisation and control of erosion rates $(\mathrm{R})$

Physical and experiential interactions (with plants, animals, landscapes, seascapes) (C)

Spiritual and/or emblematic interactions (symbolic, sacred and/or religious) (C)

Ventilation (air renewal) (R)

Wild plants, algae and their outputs for food (P)

Wild animals and their outputs for food (P)

Ecosystem disservice supply ${ }^{3}$
Abiotic-economic (e.g., Abiotic-cultural (e.g., soil erosion droughts and fires
Abiotic-cultural (e.g., soil erosion
rates, mud/landslide scar events, 
occurrence, siltation, leaching of nutrients)

Bio-economic (e.g., biological invasions, agricultural and

fisheries pests and diseases incidence, red tides)

\section{Ecosystem}

service

demand

\begin{tabular}{|c|c|c|}
\hline $\begin{array}{l}\text { Human } \\
\text { actions on }\end{array}$ & $\begin{array}{l}\text { Land cover/Land } \\
\text { use change (e.g., }\end{array}$ & $\begin{array}{l}\text { Eutrophication of } \\
\text { water bodies }\end{array}$ \\
\hline $\begin{array}{l}\text { the } \\
\text { environment }\end{array}$ & $\begin{array}{l}\text { agriculturization, } \\
\text { urbanisation, } \\
\text { land } \\
\text { abandonment) }\end{array}$ & $\begin{array}{l}\text { Land protection } \\
\text { (e.g., \% of the } \\
\text { territory declared } \\
\text { as natural protected }\end{array}$ \\
\hline
\end{tabular}

Appropriation of

Material use level (e.g., raw materials consumed per

Energy use level (e.g., energy consumed per capita and year)

Water use level (e.g., water consumed per capita and year)

Water use for irrigated crops (e.g., water use per hectare and year)

Anthropogenic water management (e.g., water delivery, drainage and storage systems)
Human Appropriation of Net Primary Production (HANPP) (e.g., Tn C extracted per hectare and year)
Net $\mathrm{CO}_{2}$ flux (e.g., CO2 emissions - CO2 sequestration)

Territorial connectivity (e.g., distance to main roads, travel time to major cities) unpleasant odours from rotting organic matter)

Abiotic-health (e.g., flood and storm events occurrence)

Bio-cultural (e.g., bird droppings on outdoor sculptures, tree roots cracking pavements)

Bio-health (e.g., human diseases incidence from pathogens, allergens)

Nature tourism (e.g., number of visitors to natural areas)
Anthropogenic carbon dioxide emissions (e.g., per capita CO2 emissions, $\mathrm{CO} 2$ emissions by sector of economic activity)

Conservation tillage (sustainable agricultural practices for soil preservation) 
Land use

area with a

intensity

management plan)

Pollution (toxic

emissions and

spills)

Soil erosion (by

anthropogenic

practices)

\begin{tabular}{|c|c|}
\hline $\begin{array}{l}\text { Social- } \\
\text { ecological } \\
\text { coupling }\end{array}$ & $\begin{array}{l}\text { Local natural } \\
\text { capital } \\
\text { dependence } \\
\text { (e.g., \% of final } \\
\text { ecosystem } \\
\text { services } \\
\text { consumed by the } \\
\text { population that } \\
\text { are provided } \\
\text { directly by local } \\
\text { environment) }\end{array}$ \\
\hline
\end{tabular}

Access to natural and seminatural areas (e.g., distance to a natural or seminatural area)

Biocapacity (capacity of ecosystems to meet people's local demand and assimilate waste products)
Ecological restoration
Import [export] rates of Airports [ports] activity agricultural products

Renewable energy use Cultural attachment to nature

(e.g., \% of energy

consumed coming from Dependence on fossil energies (e.g., \%

renewable sources) of energy consumed coming from fossil resources)

Human perception of ecosystem services (awareness level of the population about services provided by local ecosystems)

Human population ethnicity (e.g., \% of indigenous population)

Land tenure (e.g., \% communal lands vs. private lands vs. government lands)

Local green initiatives (e.g., in

agriculture, cities, touristic activities, local companies)

Non-ecosystem services demand (goods and services that do not come 
directly from ecosystems, e.g.,

socioeconomic services like hospitals,

schools or culture, internet,

manufactured products, technology)

Population employed by sectors

(agriculture vs. industry vs. services)

Population employed in traditional (vs. intensive) agriculture

Weight in the economy of the nonecosystem services market (goods and services that do not come directly from ecosystems, e.g., socioeconomic services like hospitals, schools or culture, internet, manufactured products, technology)

Weight of sectors in the economy (agriculture vs. industry vs. services)

Weight of traditional (vs. intensive) agricultural sector in the economy

† $\mathrm{P}$ = provisioning services; $\mathrm{R}$ = regulating services; $\mathrm{C}$ = cultural services.

${ }^{1}$ Foster, K. A., and W. R. Barnes. 2012. Reframing Regional Governance for Research and Practice. Urban Affairs Review 48(2):272-283. [online] URL: https://doi.org/10.1177/1078087411428121

${ }^{2}$ Haines-Young, R., and M. Potschin. 2013. Common International Classification of Ecosystem Services (CICES): Consultation on Version 4, AugustDecember 2012. [online] URL: https://www.cices.eu 
${ }^{3}$ Shackleton, C. M., S. Ruwanza, G. K. Sinasson Sanni, S. Bennett, P. De Lacy, R. Modipa, N. Mtati, M. Sachikonye, and G. Thondhlana. 2016. Unpacking Pandora's Box: Understanding and Categorising Ecosystem Disservices for Environmental Management and Human Wellbeing. Ecosystems 19(4):587-600. [online] URL: https://doi.org/10.1007/s10021-015-9952-z

In this paper, ecosystem disservices are defined as "the ecosystem generated functions, processes and attributes that result in perceived or actual negative impacts on human wellbeing."

We based on Shackleton et al. (2016) classification to distinguish among 6 categories of ecosystem disservices, according to their origin (biological or abiotic) and the nature of their impacts on human wellbeing (economic; physical and mental health and safety; aesthetics and culture): bio-economic, abiotic-economic, bio-health, abiotic-health, bio-cultural, abiotic-cultural. Examples of ecosystem disservices for each category are include in the Table above. 
Table A5.3. Examples of studies that have used prioritized variables to map SES distribution and dynamics. The specific metrics used to map SESs associated with the priority variables identified in our study are listed. Nonpriority variables (those that obtained the lowest scores in the survey) and additional variables not included in our list are also matched to the metrics used to map SESs.

\begin{tabular}{|c|c|c|c|c|}
\hline Component & Variable & $\begin{array}{l}\text { Variable } \\
\text { priority level }\end{array}$ & Reference & Metric \\
\hline \multirow[t]{26}{*}{ Social system } & \multirow[t]{6}{*}{ Educational level } & \multirow[t]{6}{*}{2} & Castellarini et al. (2014) & Human Development Index \\
\hline & & & Hamann et al. (2016) & $\begin{array}{l}\text { People with completed secondary schooling or } \\
\text { higher }\end{array}$ \\
\hline & & & Martín-López et al. (2017) & Illiterates \\
\hline & & & & People with university degree \\
\hline & & & Rocha et al. (2020) & Literacy rate \\
\hline & & & Vallejos et al. (2020) & School density \\
\hline & \multirow[t]{4}{*}{ Poverty } & \multirow[t]{4}{*}{2} & Václavík et al. (2013) & Gross Domestic Product \\
\hline & & & Castellarini et al. (2014) & Human Development Index \\
\hline & & & Hamann et al. (2016) & Household income \\
\hline & & & Vallejos et al. (2020) & Unsatisfied basic needs \\
\hline & \multirow[t]{3}{*}{ Environmental quality } & \multirow[t]{3}{*}{2} & Queiroz et al. (2015) & Standing water quality \\
\hline & & & & Running water quality \\
\hline & & & Dittrich et al. (2017) & Soil quality \\
\hline & Conflicts & 2 & Dressel et al. (2018) & $\begin{array}{l}\text { Potential for conflict index on moose managers } \\
\text { evaluation of moose population }\end{array}$ \\
\hline & \multirow[t]{12}{*}{ Population density } & \multirow[t]{12}{*}{3} & Ellis and Ramankutty (2008) & \multirow[t]{10}{*}{ Population density } \\
\hline & & & Asselen and Verburg (2012) & \\
\hline & & & Václavík et al. (2013) & \\
\hline & & & Hamann et al. (2015) & \\
\hline & & & Renard et al. (2015) & \\
\hline & & & Dittrich et al. (2017) & \\
\hline & & & Martín-López et al. (2017) & \\
\hline & & & Spake et al. (2017) & \\
\hline & & & Levers et al. (2018) & \\
\hline & & & Vallejos et al. (2020) & \\
\hline & & & Rocha et al. (2020) & Population density \\
\hline & & & & Change in population density \\
\hline
\end{tabular}


Political stability

Population size

Migrations

Age structure

nonpriority

nonpriority

Sex ratio

Life expectancy

Employment

Access to internet

nonpriority

nonpriority

nonpriority

nonpriority
Václavík et al. (2013)

Hanspach et al. (2016)

Hanspach et al. (2016)

Martín-López et al. (2017)

Rocha et al. (2020)

Hanspach et al. (2016)

Martín-López et al. (2017)

\section{Rocha et al. (2020)}

Dittrich et al. (2017)

Rocha et al. (2020)

Hamann et al. (2016)

Hamann et al. (2016)

Hanspach et al. (2016)

Dittrich et al. (2017)

Martín-López et al. (2017)

Levers et al. (2018)

Vallejos et al. (2020)

Václavík et al. (2013)

Castellarini et al. (2014)

Hamann et al. (2015)

Hamann et al. (2016)

Martín-López et al. (2017)

Levers et al. (2018)
Urban and non-urban population

Political stability index

Total population size

Net migration

Foreign population

Inter \& intra regional migrations

Proportion of pupils

People younger than 20

People older than 65

Ratio of children

Ratio female/male

Ratio of woman

Average age of death

Unemployed people

Discouraged work-seeker

Unemployment rate

Unemployment rate

Unemployed inhabitants

Total labour input

Permanent workers

Gross Domestic Product

Human Development Index

Household income

Household income

Income per capita

Economic activity index

Number of ADSL lines 
Internal capacity of the

nonpriority

Dittrich et al. (2017)

government

Stakeholders participation in decision making

Ecological system

Precipitation

Asselen and Verburg (2012)

Václavík et al. (2013)

Dittrich et al. (2017)

Martín-López et al. (2017)

Spake et al. (2017)

Rocha et al. (2020)

Net Primary Productivity

Organic carbon storage
Alessa et al. (2008)

Ellis and Ramankutty (2008)

Václavík et al. (2013)

Hamann et al. (2015)

Spake et al. (2017)

Vallejos et al. (2020)

Raudsepp-Hearne et al. (2010) Asselen and Verburg (2012)

Spake et al. (2017)

Levers et al. (2018)

Martín-López et al. (2017)
Václavík et al. (2013)

Renard et al. (2015)
Property ownership (Percentage of households where dwelling is owned and fully paid off

\section{District debts}

Proportion of general public that are relevant actors

Precipitation

Precipitation

Precipitation seasonality

Mean precipitation vegetation period

Mean annual precipitation

Minimum annual precipitation

Maximum annual precipitation

Annual precipitation

Number of months with precipitation $>60 \mathrm{~mm}$

Net Primary Productivity Index

Net Primary Productivity $\left(\mathrm{g} \mathrm{m}^{-2}\right)$

NDVI - mean

NDVI - seasonality

Area with high grazing potential

Potential Net Primary Productivity ( $\mathrm{tC} \mathrm{m}^{-2} \mathrm{yr}$ )

EVI - mean

EVI - seasonality

Carbon sequestration ( $\mathrm{kg} \mathrm{C} \mathrm{km}^{-2}$ )

Soil organic carbon (g C kg-1 of soil)

Soil organic carbon ( $\mathrm{g} \mathrm{C} \mathrm{kg}^{-1}$ of soil)

Carbon sequestration $\left(\mathrm{kg} \mathrm{C} \mathrm{km}^{-2}\right)$

Carbon stocks from above-ground and belowground biomass, dead organic matter and soils (tC km-2)

Soil organic carbon (tC ha-1)

Mean annual evapotranspiration 
Actual water deficit (or

excess)

Net solar radiation

Soil phosphorus availability

Land surface temperature

Groundwater depth

Biodiversity

Natural capital

Other abiotic conditions
Levers et al. (2018)

Rocha et al. (2020)

Václavík et al. (2013)

Dittrich et al. (2017)

Raudsepp-Hearne et al. (2010)

Queiroz et al. (2015)

Asselen and Verburg (2012)

Václavík et al. (2013)

Dittrich et al. (2017)

Levers et al. (2018)

Rocha et al. (2020)

nonpriority

Dittrich et al. (2017)

not in our list

áclavík et al. (2013)

Castellarini et al. (2014)

Hanspach et al. (2016)

Spake et al. (2017)

Levers et al. (2018)

not in our list Vallejos et al. (2020)

not in our list
Asselen and Verburg (2012)

Castellarini et al. (2014)

Renard et al. (2015)

Hanspach et al. (2016)
Minimum annual evapotranspiration

Maximum annual evapotranspiration

Ratio of mean annual precipitation \& mean annual potential evapotranspiration

Mean aridity gradient

Solar radiation $\left(\mathrm{W} \mathrm{m}^{-2}\right)$

Mean sunshine duration

Soil phosphorus retention

Mean temperature

Temperature

Diurnal temperature range

Extreme temperatures

Mean temperature vegetation period

Growing degree days $\left(\mathrm{T}>0^{\circ}\right)$

Mean temperature

Groundwater level

Species richness

Distribution of ecoregions

Species richness

Species richness

Distribution of ecoregions

Native forest area

Soil characteristics

Altitude

Slope

Ecorregions map

Soil capability for agriculture

Altitude

Terrain ruggedness 
Slope

Spake et al. (2017)

Livestock production
Sinare et al. (2016)

Dittrich et al. (2017)

Martín-López et al. (2017)

Spake et al. (2017)

Levers et al. (2018)

Rocha et al. (2020)

Raudsepp-Hearne et al. (2010)

Václavík et al. (2013)

Hamann et al. (2015)

Queiroz et al. (2015)

Renard et al. (2015)

Dittrich et al. (2017)

Levers et al. (2018)

Rocha et al. (2020)

Vallejos et al. (2020)

Terrain wetness index

Heatload

Topography

Ruggedness

Altitude

Slope

Lithology

Geomorphology

Elevation

Topographic heterogeneity

Slope

\section{Cropland production}

Variance of crop production Kilocalories for diverse crops Annual crops area

Raudsepp-Hearne et al. (2010)

Asselen and Verburg (2012)

Hamann et al. (2015)

Queiroz et al. (2015)

Renard et al. (2015)

Dittrich et al. (2017)

Martín-López et al. (2017)

Levers et al. (2018)

Rocha et al. (2020)

Vallejos et al. (2020)
Livestock production

\section{Cattle per $\mathrm{km}^{2}$}

Small ruminants per capita

Forage crops area

Pregnant cows 
Surface and groundwater sources for drinking

Hydrological cycle and water flow maintenance

Land cover/Land use change

Land use intensity
Renard et al. (2015)

Dittrich et al. (2017)

Spake et al. (2017)

Rocha et al. (2020)

Ellis and Ramankutty (2008)* Asselen and Verburg (2012)* Václavík et al. (2013)

Castellarini et al. (2014)*

Hamann et al. (2015)*

Hanspach et al. (2016)*

Sinare et al. (2016)*

Martín-López et al. (2017) *

Spake et al. (2017)*

Levers et al. (2018)

Vallejos et al. (2020)*

Dressel et al. (2018)

Asselen and Verburg (2012)

Václavík et al. (2013)

Hanspach et al. (2016)

Martín-López et al. (2017)

Levers et al. (2018)

Vallejos et al. (2020)
Drinking water quality - IQBP indicator (1-5)

Clean water - nitrogen concentration in rivers (mg $\mathrm{N} \mathrm{l}^{-1}$ )

Mean annual runoff

Flood control

Flood protection (biophysical dependent flood

regulation by catchments)

Physical water quantity regulation

Soil water holding capacity

Multiple categories

* (These studies include land cover and land use variables but not address changes directly)

\section{Diversity of land cover type}

Efficiency of agricultural production

Multidimensional (N fertilizer, irrigation, soil erosion, yields, HANPP)

Landscape heterogeneity

Cropland irrigation

Greenhouses crops

Wood production

Fertilizer application rates

Yields

Stocking density

Grassland yields

Irrigated area

Tractor density

Stocking density 
Local natural capital dependence

Water use for irrigated crops

Appropriation of land for agriculture

Pollination and seed dispersal

Martín-López et al. (2017) Rocha et al. (2020)

Václavík et al. (2013)

Ellis and Ramankutty (2008)

Raudsepp-Hearne et al. (2010)

Asselen and Verburg (2012)

Václavík et al. (2013)

Hamann et al. (2015)

Renard et al. (2015)

Queiroz et al. (2015)

Hanspach et al. (2016)

Spake et al. (2017)

Martín-López et al. (2017)

Levers et al. (2018)

Queiroz et al. (2015)

Dittrich et al. (2017)

Dressel et al. (2018)

\section{Soil erosion}

Surface in the municipality in the protected area Protected area coverage (Natura 2000)

Changes in protected areas (Natura 2000)

Demand of ecosystem services provided by the local environment (wood for heating, wood production, crop production, animal production, freshwater, building materials)

Female headed households

Use of freshwater from a natural source (a river or spring)

Water consumption

Dams

Irrigated surface

Surface dedicated to agriculture

Amount of pollinator habitat within a buffer of 200m from crop production areas

Pollination potential (habitat suitable for pollinators)

Competition (presence of other ungulate species) Predation (presence of bears) 
Human Appropriation of Net Primary Production (HANPP)

Territorial connectivity

Václavík et al. (2013)

Hamann et al. (2015)

Renard et al. (2015)

Hanspach et al. (2016)

Levers et al. (2018)

Rocha et al. (2020)

Vallejos et al. (2020)
Import and export rates of

agricultural products

Wild plants, algae and their outputs for food

Fibres and other materials

from plants, algae and animals for direct use or

processing

Wild animals and their outputs for food (P)

Biomass-based energy

nonpriority

Asselen and Verburg (2012)

Raudsepp-Hearne et al. (2010)

Dressel et al. (2018)

Levers et al. (2018)

Dressel et al. (2018) sources
Predation (presence of wolves)

Fresh browsing damage on Scots pine (Pinus sylvestris)

\section{HANPP}

HANPP harvest for arable croplands, permanent crops and grasslands

Accessibility (travel time to major cities and market places)

Distance to city

Distance from main city

Remoteness (travel time by car to the next town $>$ 20000)

Accessibility (travel time to major city $>50000$ )

Market access index

Transport network connectivity (road density)

Market influence

Market accessibility

Maple syrup

Index of moose forage availability

Variation in moose forage availability over 10 years

Grassland yields

Wood production

Size of moose management area

Number of shot moose per square kilometre

Ratio of moose to other ungulate species

Frequency of moose meat consumption

Wood for cooking, wood for heating

Energy crops (amount of methane provided by crops for biogas production) 


\section{Spake et al. (2017)}

\section{Bioremediation}

nonpriority

Dittrich et al. (2017)

Bio-health ecosystem

disservices

Human perceptions of ecosystem services

Nitrogen fertilizer

Urban solid waste

Weight of sectors in the economy

Land tenure nonpriority

Dressel et al. (2018)

nonpriority

Sinare et al. (2016)

not in our list

Václavík et al. (2013)

Levers et al. (2018)

not in our list Martín-López et al. (2017)

nonpriority

Václavík et al. (2013)

Martín-López et al. (2017)

Levers et al. (2018)

Rocha et al. (2020)

nonpriority
Hamann et al. (2015) Dressel et al. (2018)
Levers et al. (2018)

Vallejos et al. (2020)
Potential woody biomass supply for stemwood and logging residues

\section{Ability of rivers to remove nitrogen}

Number of moose-car-collisions

Use of ecosystem services reported by locals

Fertilized surface

Fertilizer application rates [ $\left.\mathrm{kg} \mathrm{ha}^{-1}\right] ;<50 \mathrm{~kg} \mathrm{ha}^{-1}$, 50-150 kg ha-1, >150 kg ha-1

Urban solid waste production (Ton year-1 $\mathrm{ha}^{-1}$ )

GDP in agriculture

Capital stock in agriculture

Hotel bedroom places

Economic size of farms

Total monetary inputs in farms

Ratio of farmers

Area under traditional authority rule Level of self-organization (geographic coverage of moose management units)

Number of sub-units (i.e. license areas) per moose management area

Diversity index of forest ownership types

Diversity index of agriculture ownership types Property size classes of private forest owners

Total utilised agricultural area (owner occupation or rented for $>=1$ year)

Area with legal type of farmer 'Physical Person' Area with land tenure regime 'Owner' 


\section{Literature cited in Table A5.3.}

Alessa, L., A. Kliskey, and G. Brown. 2008. Social-ecological hotspots mapping: A spatial approach for identifying coupled social-ecological space. Landscape and Urban Planning 85(1):27-39.

Asselen, S. van, and P. H. Verburg. 2012. A Land System representation for global assessments and land-use modeling. Global Change Biology 18(10):31253148.

Castellarini, F., C. Siebe, E. Lazos, B. de la Tejera, H. Cotler, C. Pacheco, E. Boege, A. R. Moreno, A. Saldivar, A. Larrazábal, C. Galán, J. M. Casado, and P. Balvanera. 2014. A social-ecological spatial framework for policy design towards sustainability: Mexico as a study case. Investigación ambiental Ciencia y política pública $6(2)$.

Dittrich, A., R. Seppelt, T. Václavík, and A. F. Cord. 2017. Integrating ecosystem service bundles and socio-environmental conditions - A national scale analysis from Germany. Ecosystem Services 28:273-282.

Dressel, S., G. Ericsson, and C. Sandström. 2018. Mapping social-ecological systems to understand the challenges underlying wildlife management. Environmental Science \& Policy 84:105-112.

Ellis, E. C., and N. Ramankutty. 2008. Putting people in the map: anthropogenic biomes of the world. Frontiers in Ecology and the Environment 6(8):439-447.

Hamann, M., R. Biggs, and B. Reyers. 2015. Mapping social-ecological systems: Identifying 'green-loop' and 'red-loop' dynamics based on characteristic bundles of ecosystem service use. Global Environmental Change 34:218-226.

Hamann, M., R. Biggs, and B. Reyers. 2016. An Exploration of Human Well-Being Bundles as Identifiers of Ecosystem Service Use Patterns. PLOS ONE 11(10):e0163476.

Hanspach, J., J. Loos, I. Dorresteijn, D. J. Abson, and J. Fischer. 2016. Characterizing social-ecological units to inform biodiversity conservation in cultural landscapes. Diversity and Distributions 22(8):853-864.

Levers, C., D. Müller, K. Erb, H. Haberl, M. R. Jepsen, M. J. Metzger, P. Meyfroidt, T. Plieninger, C. Plutzar, J. Stürck, P. H. Verburg, P. J. Verkerk, and T. Kuemmerle. 2018. Archetypical patterns and trajectories of land systems in Europe. Regional Environmental Change 18(3):715-732.

Martín-López, B., I. Palomo, M. García-Llorente, I. Iniesta-Arandia, A. J. Castro, D. García Del Amo, E. Gómez-Baggethun, and C. Montes. 2017. Delineating boundaries of social-ecological systems for landscape planning: A comprehensive spatial approach. Land Use Policy 66:90-104. 
Queiroz, C., M. Meacham, K. Richter, A. V. Norström, E. Andersson, J. Norberg, and G. Peterson. 2015. Mapping bundles of ecosystem services reveals distinct types of multifunctionality within a Swedish landscape. AMBIO 44(1):89-101.

Raudsepp-Hearne, C., G. D. Peterson, and E. M. Bennett. 2010. Ecosystem service bundles for analyzing tradeoffs in diverse landscapes. Proceedings of the National Academy of Sciences 107(11):5242-5247.

Renard, D., J. M. Rhemtulla, and E. M. Bennett. 2015. Historical dynamics in ecosystem service bundles. Proceedings of the National Academy of Sciences 112(43):13411-13416.

Rocha, J., K. Malmborg, L. Gordon, K. Brauman, and F. DeClerck. 2020. Mapping social-ecological systems archetypes. Environmental Research Letters 15(3):034017.

Sinare, H., L. J. Gordon, and E. Enfors Kautsky. 2016. Assessment of ecosystem services and benefits in village landscapes - A case study from Burkina Faso. Ecosystem Services 21:141-152.

Spake, R., R. Lasseur, E. Crouzat, J. M. Bullock, S. Lavorel, K. E. Parks, M. Schaafsma, E. M. Bennett, J. Maes, M. Mulligan, M. Mouchet, G. D. Peterson, C. J. E. Schulp, W. Thuiller, M. G. Turner, P. H. Verburg, and F. Eigenbrod. 2017. Unpacking ecosystem service bundles: Towards predictive mapping of synergies and trade-offs between ecosystem services. Global Environmental Change 47:37-50.

Václavík, T., S. Lautenbach, T. Kuemmerle, and R. Seppelt. 2013. Mapping global land system archetypes. Global Environmental Change 23(6):1637-1647.

Vallejos, M., S. Aguiar, G. Baldi, M. E. Mastrángelo, F. Gallego, M. Pacheco-Romero, D. Alcaraz-Segura, and J. M. Paruelo. 2020. Social-Ecological Functional Types: Connecting People and Ecosystems in the Argentine Chaco. Ecosystems 23(3): 471-484. 
Appendix 6. Figures.

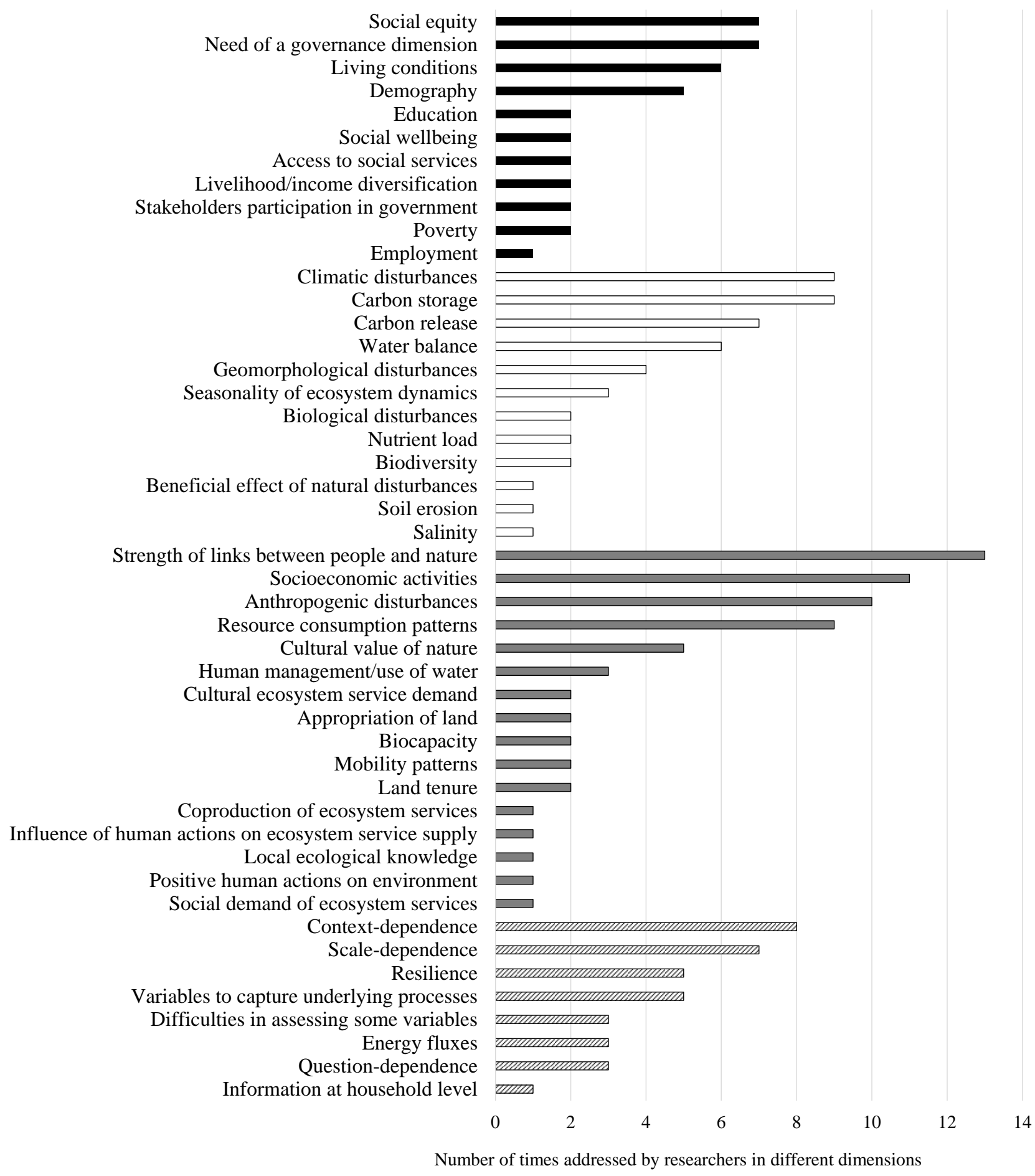

Figure A6.1. Featured topics identified from suggestions and comments in the preliminary survey, which were used to improve the preliminary list of variables and dimensions for characterizing and monitoring SES. Black, white and gray bars represent the social system, ecological system and interaction components, respectively, while stripped bars reflect issues that are transversal to the whole conceptual framework. (See also these topics in the conceptual map of Appendix 7). 
Figures A6.2 to A6.14. Detail view of the relationship between average relevance and consensus obtained by the variables belonging to each dimension of social-ecological system functioning. Relevance was evaluated as the mean of the scores assigned by experts to each variable. The consensus was estimated as the difference between the maximum standard deviation of the scores found throughout the 149 variables and the standard deviation of the score for each variable (low differences indicated low consensus and high differences, high consensus). Horizontal and vertical lines represent the 25th, 50th, $75^{\text {th }}$ and $90^{\text {th }}$ percentiles of relevance and consensus for the whole set of variables belonging to the 13 dimensions of social-ecological functioning. Boxes over the grid illustrate the clustering of the variables by priority levels. The red box (priority level 1) includes those variables with relevance and consensus above the $90^{\text {th }}$ percentile; the green box (level 2) includes those variables with both values between the $75^{\text {th }}$ and $90^{\text {th }}$ percentiles; the yellow box (level 3 ) includes those with relevance above the $75^{\text {th }}$ percentile but consensus between the $50^{\text {th }}$ and $75^{\text {th }}$ percentiles and vice versa; and the blue box (level 4) includes variables with relevance and consensus between the $50^{\text {th }}$ and $75^{\text {th }}$ percentiles. At the bottom right of each figure, the equation of the regression line, the significance of the line slope (p-value) and the root-mean-square error (RMSE) are indicated, as are the number of variables ( $n$ ), the Spearman's correlation coefficient $(r)$ and its significance (pvalue).

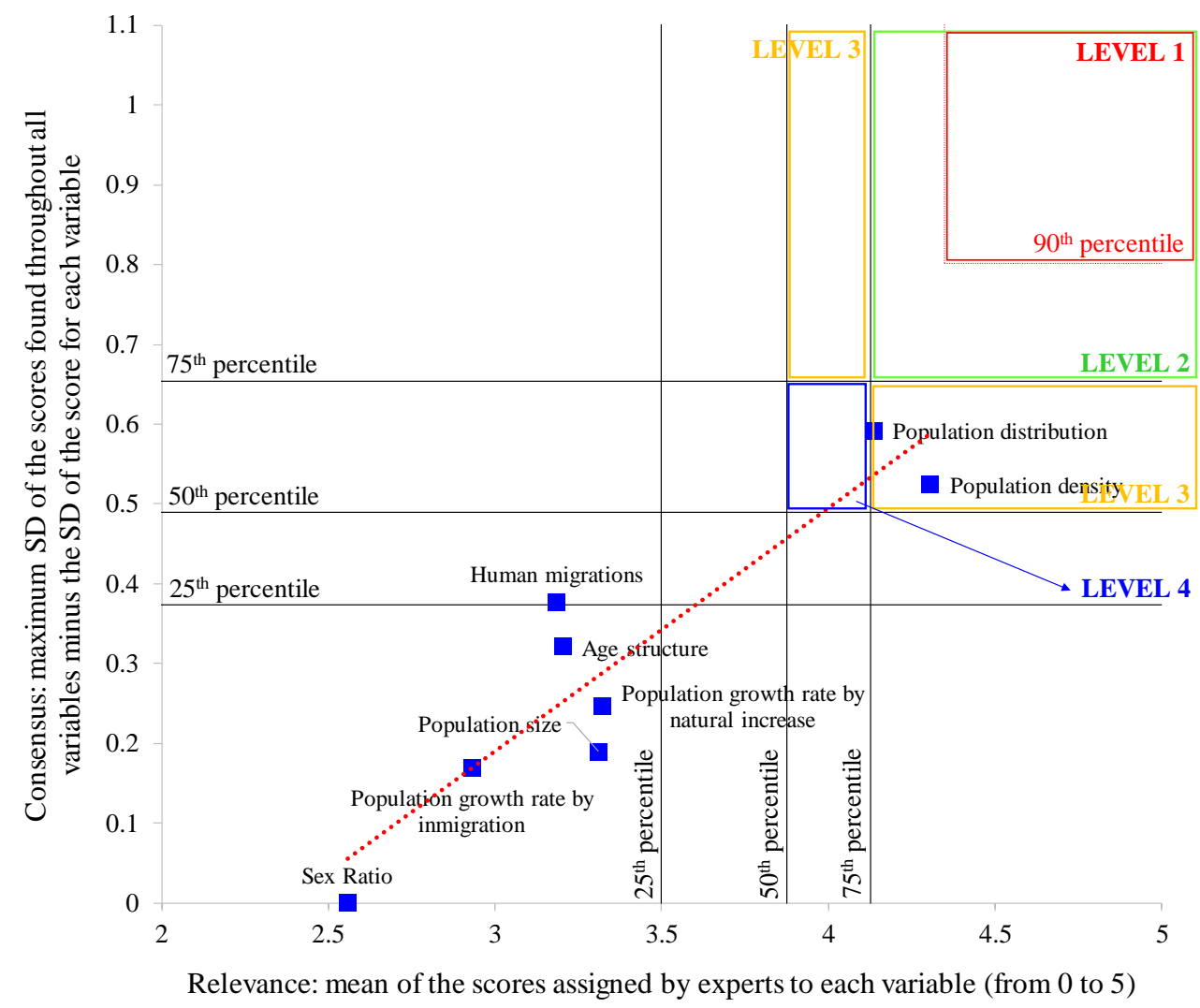

A6.2

Component: social system

Dimension: human population dynamics

$\cdots \cdot$... Regression line

$y=-0.73+0.31 x$

p-value $=0.001$

RMSE $=0.07$

$\mathrm{n}=8 ; \mathrm{r}=0.76$

$\mathrm{p}$-value $=0.037$ 


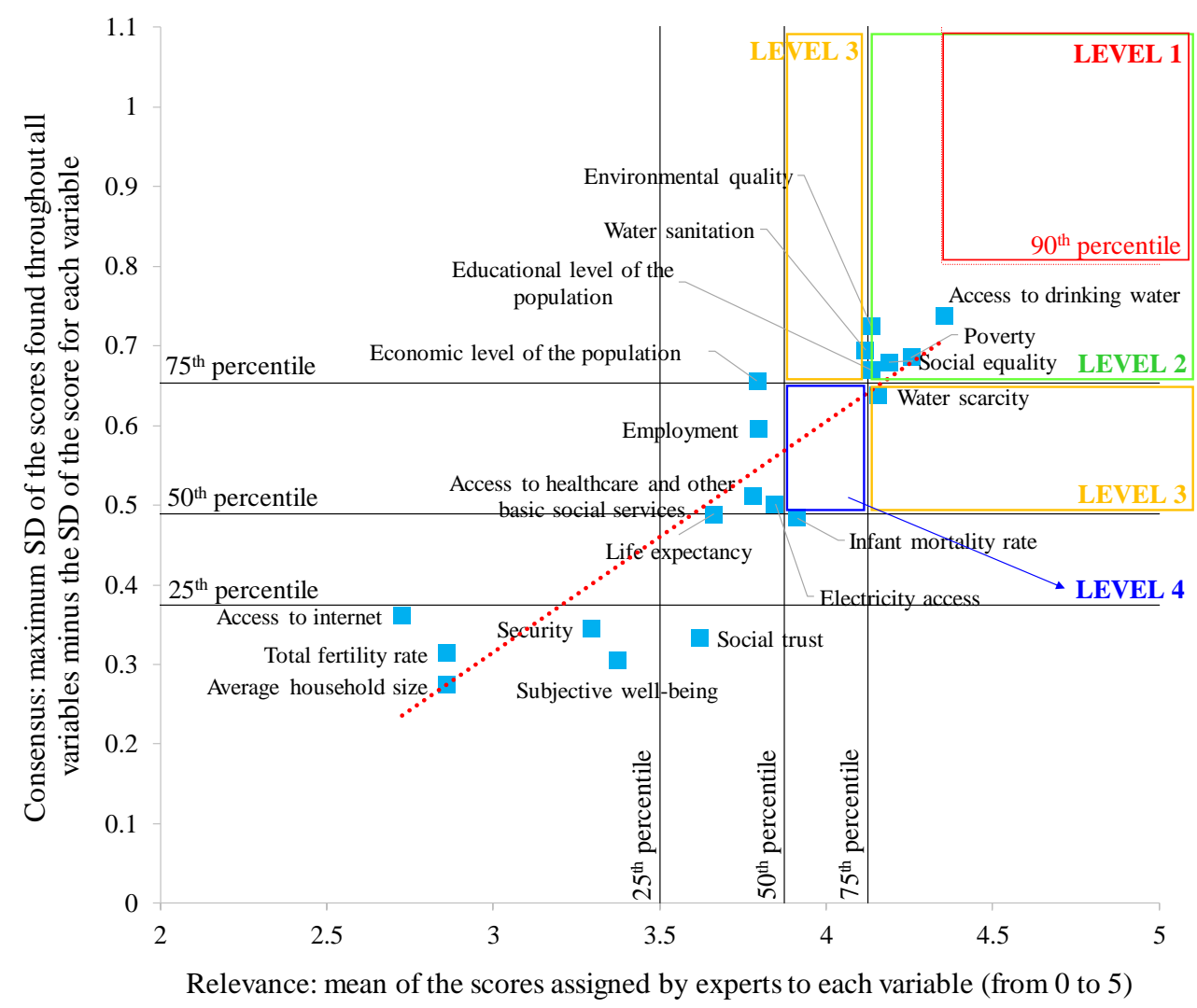

A6.3

Component: social system

Dimension: wellbeing and development

..... Regression line $y=-0.55+0.29 x$

p-value $<0.001$

RMSE $=0.07$

$\mathrm{n}=19 ; \mathrm{r}=0.87$ p-value $<0.001$

A6.4

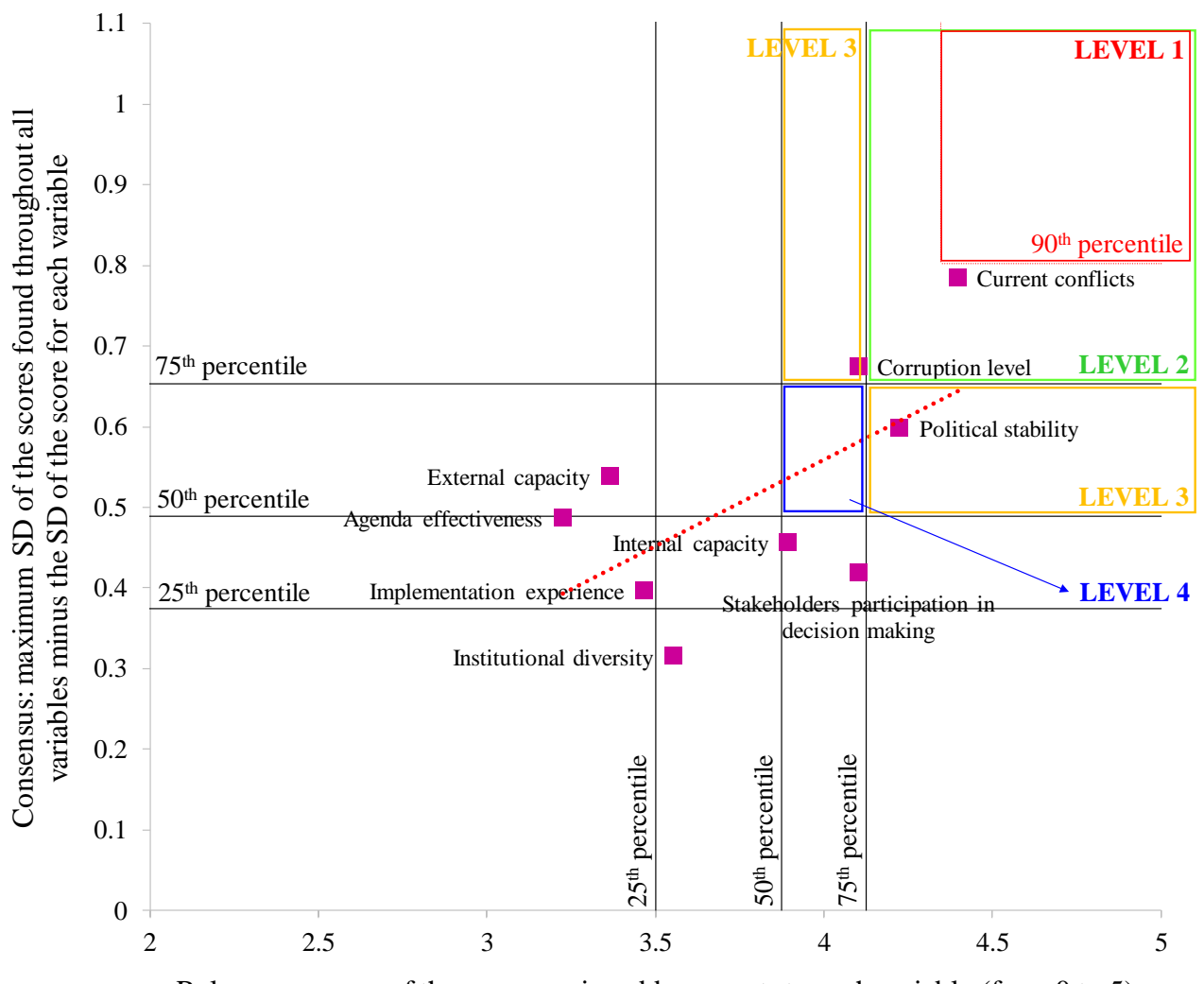

..... Regression line $\mathrm{y}=-0.30+0.21 \mathrm{x}$ $\mathrm{p}$-value $=0.079$ RMSE $=0.11$

$\mathrm{n}=9 ; \mathrm{r}=0.51$ $\mathrm{p}$-value $=0.160$

Component: social system

Dimension: governance

Relevance: mean of the scores assigned by experts to each variable (from 0 to 5 ) 


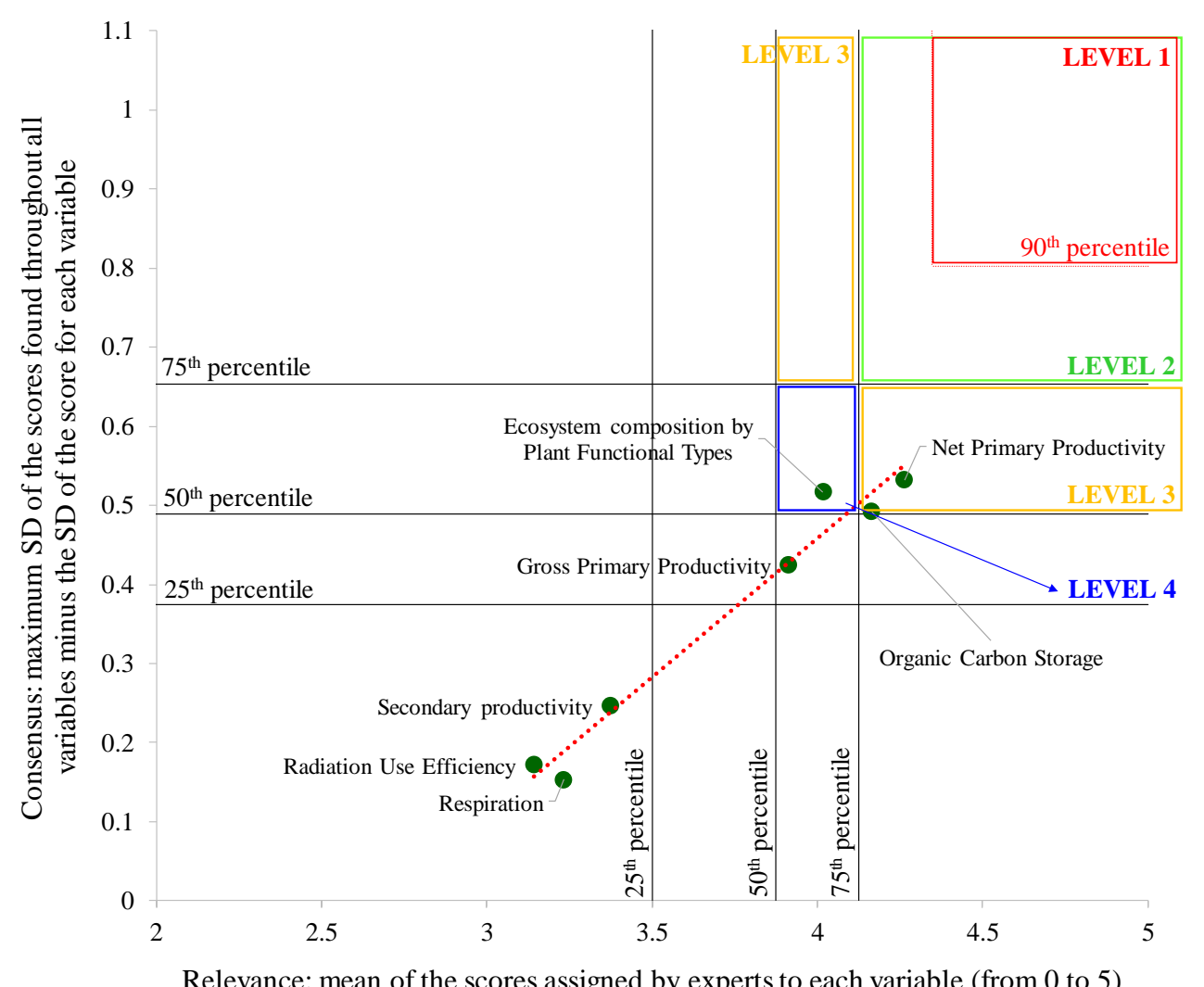

Relevance: mean of the scores assigned by experts to each variable (from 0 to 5 )

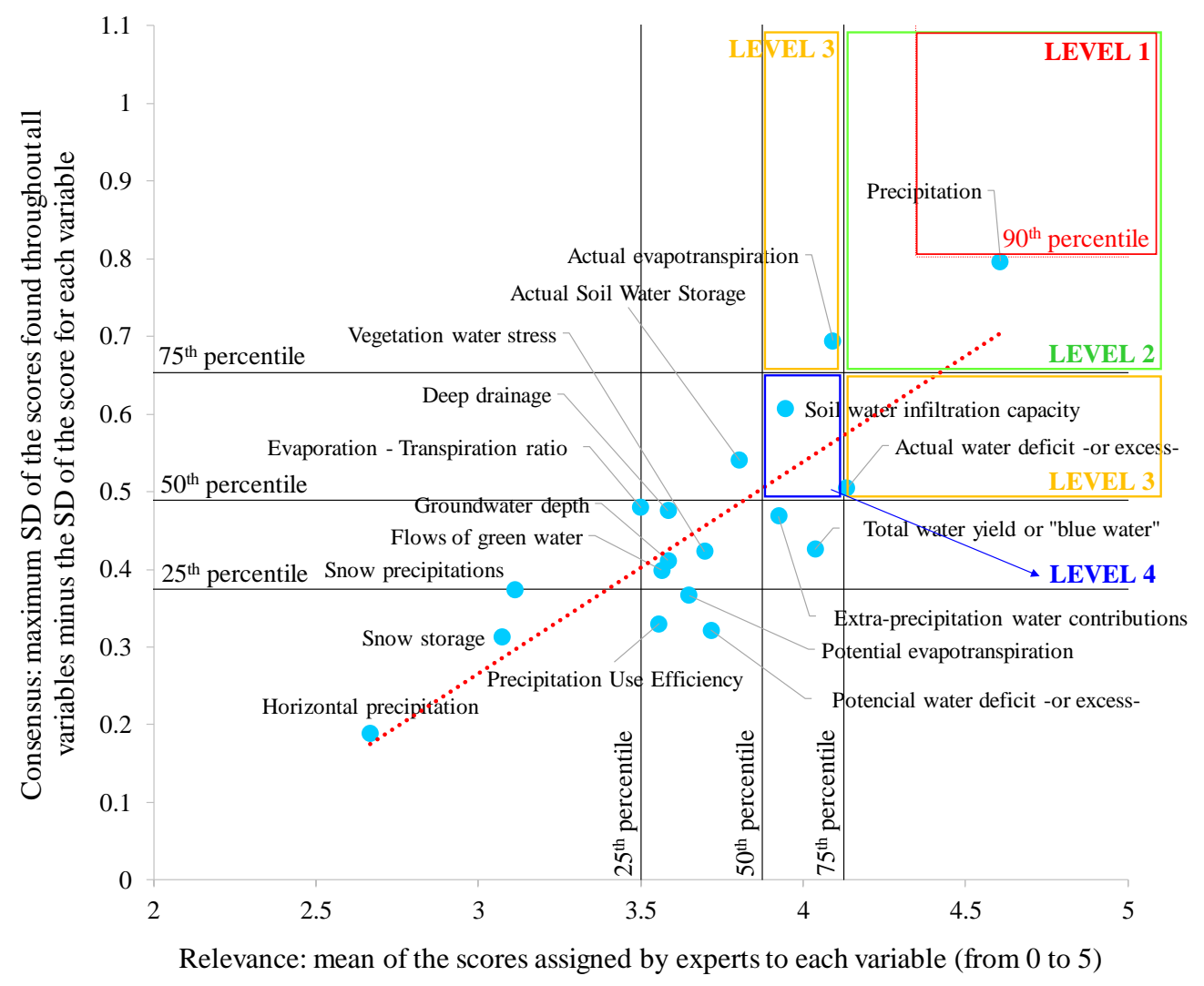

A6.5

Component: ecological system

Dimension: organic carbon dynamics

.... Regression line

$y=-0.95+0.35 x$

p-value $<0.001$

RMSE $=0.03$

$\mathrm{n}=7 ; \mathrm{r}=0.93$

$\mathrm{p}$-value $=0.007$

\section{A6.6}

Component: ecological system

Dimension: water dynamics

\footnotetext{
.... Regression line

$\mathrm{y}=-0.55+0.27 \mathrm{x}$

p-value $<0.001$

RMSE $=0.08$

$\mathrm{n}=18 ; \mathrm{r}=0.75$

p-value $<0.001$
} 

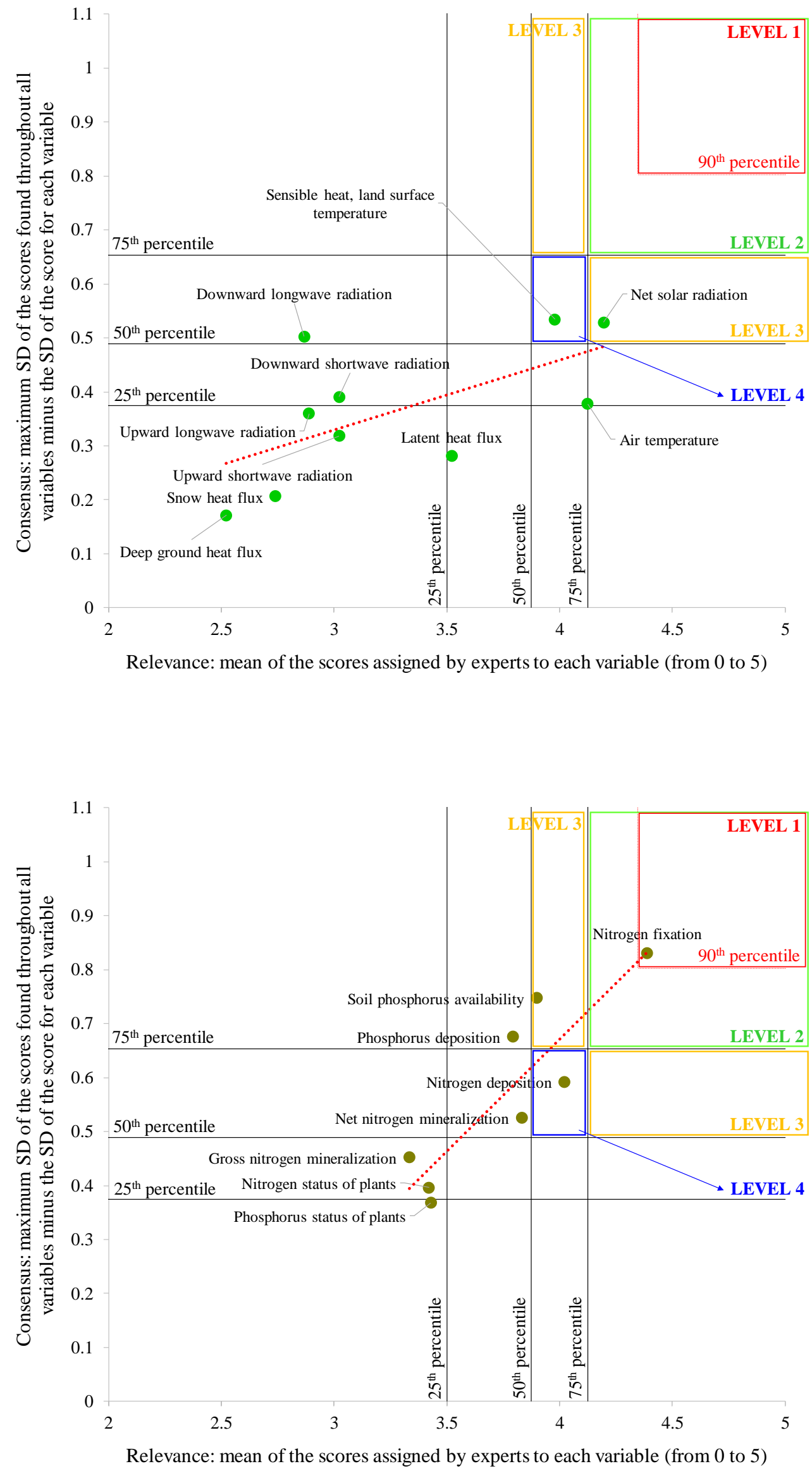

A6.7

Component: ecological system

Dimension: surface energy balance

..... Regression line $y=-0.06+0.13 x$ $\mathrm{p}$-value $=0.055$ RMSE $=0.10$ $\mathrm{n}=10 ; \mathrm{r}=0.65$ $\mathrm{p}$-value $=0.050$

\section{A6.8}

Component: ecological system

Dimension: nutrient cycling

$$
\begin{aligned}
& \cdots \cdot \text { Regression line } \\
& \mathrm{y}=-0.99+0.41 \mathrm{x} \\
& \mathrm{p} \text {-value }=0.004 \\
& \text { RMSE }=0.07
\end{aligned}
$$$$
\mathrm{n}=8 ; \mathrm{r}=0.79
$$$$
\mathrm{p} \text {-value }=0.028
$$ 


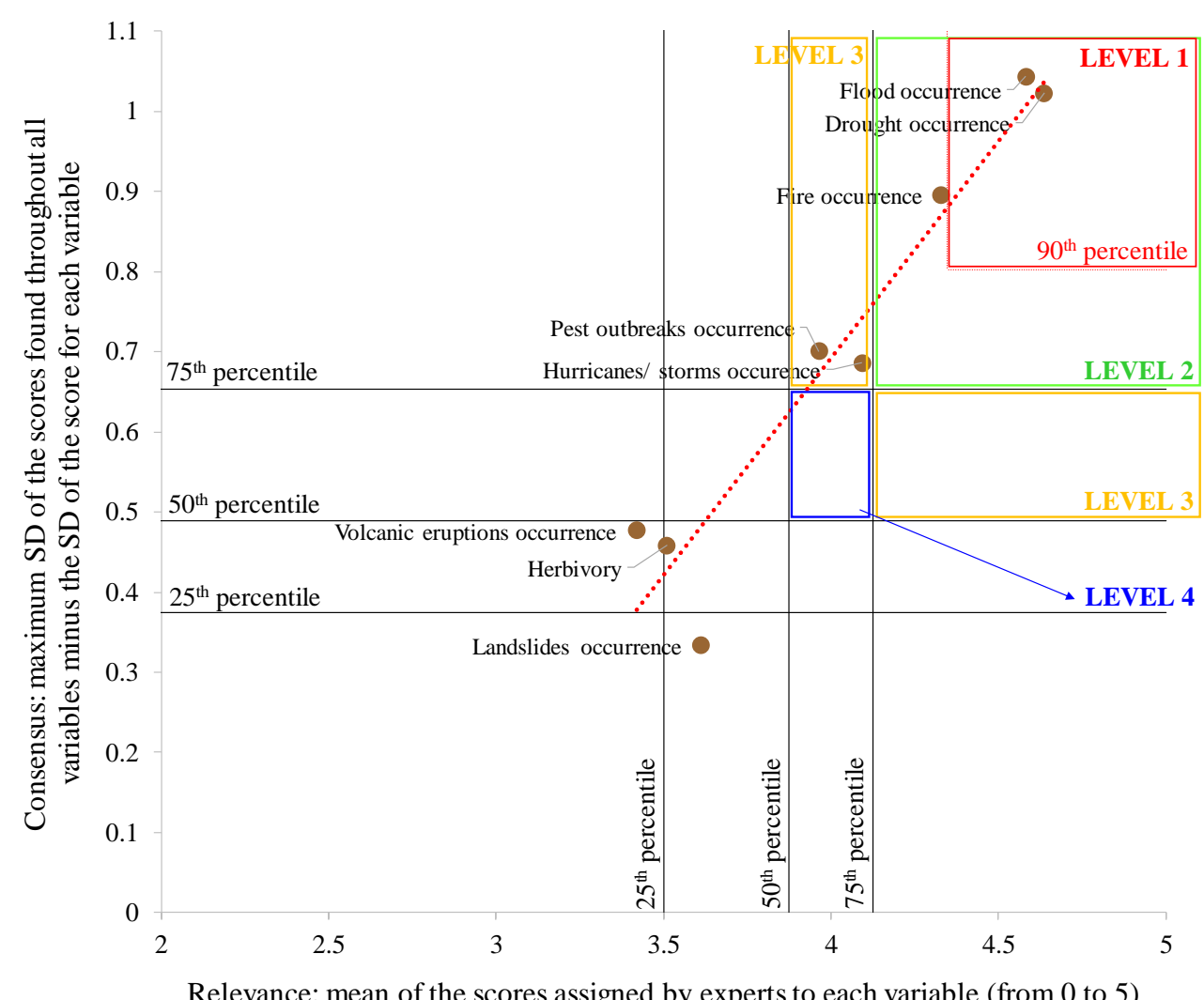

Relevance: mean of the scores assigned by experts to each variable (from 0 to 5 )

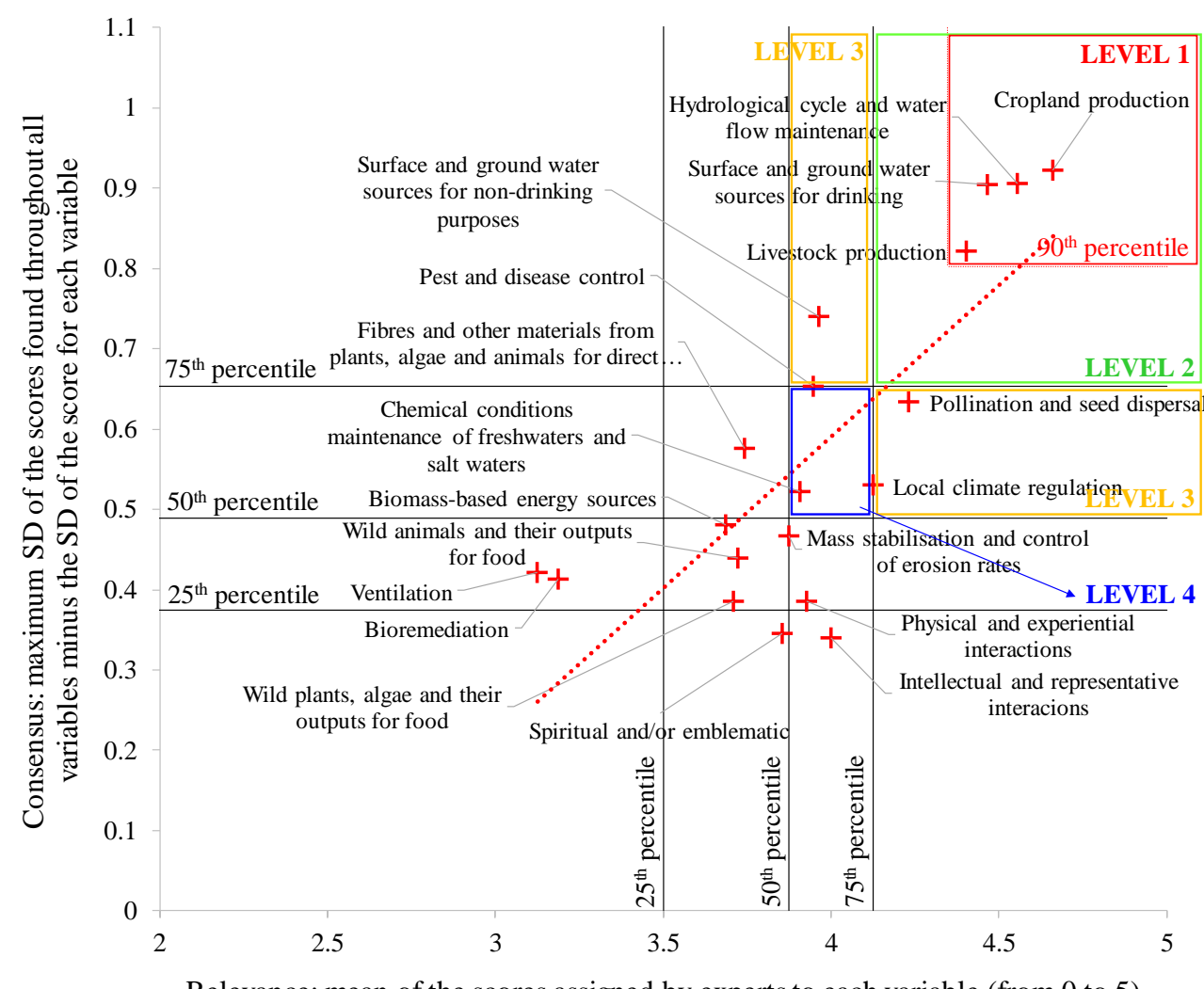

Relevance: mean of the scores assigned by experts to each variable (from 0 to 5 )
A6.9

Component: ecological system

Dimension: disturbance regime

-.... Regression line $\mathrm{y}=-1.47+0.54 \mathrm{x}$ p-value $<0.001$ RMSE $=0.07$ $\mathrm{n}=8 ; \mathrm{r}=0.86$ $\mathrm{p}$-value $=0.011$

A6.10

Component: interactions Dimension: ecosystem service supply

$$
\begin{aligned}
& \cdots \cdot \cdot \text { Regression line } \\
& \mathrm{y}=-0.92+0.38 \mathrm{x} \\
& \mathrm{p} \text {-value }<0.001 \\
& \text { RMSE }=0.12 \\
& \mathrm{n}=19 ; \mathrm{r}=0.69 \\
& \mathrm{p} \text {-value }=0.001
\end{aligned}
$$




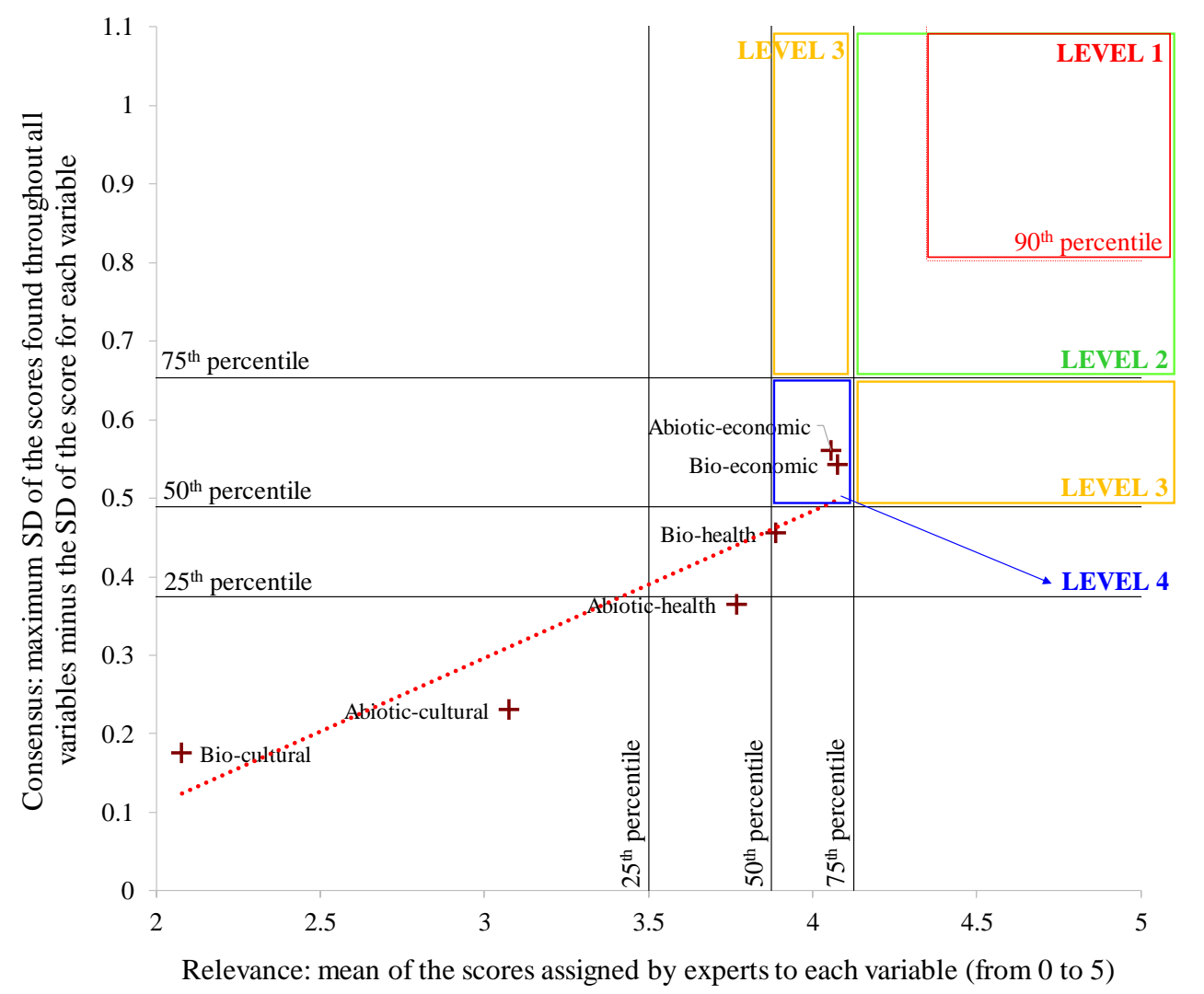

A6.11

Component: interactions Dimension: ecosystem disservice supply

.... Regression line $y=-0.26+0.19 x$ $\mathrm{p}$-value $=0.011$ RMSE $=0.06$

$\mathrm{n}=6 ; \mathrm{r}=0.94$ $\mathrm{p}$-value $=0.017$

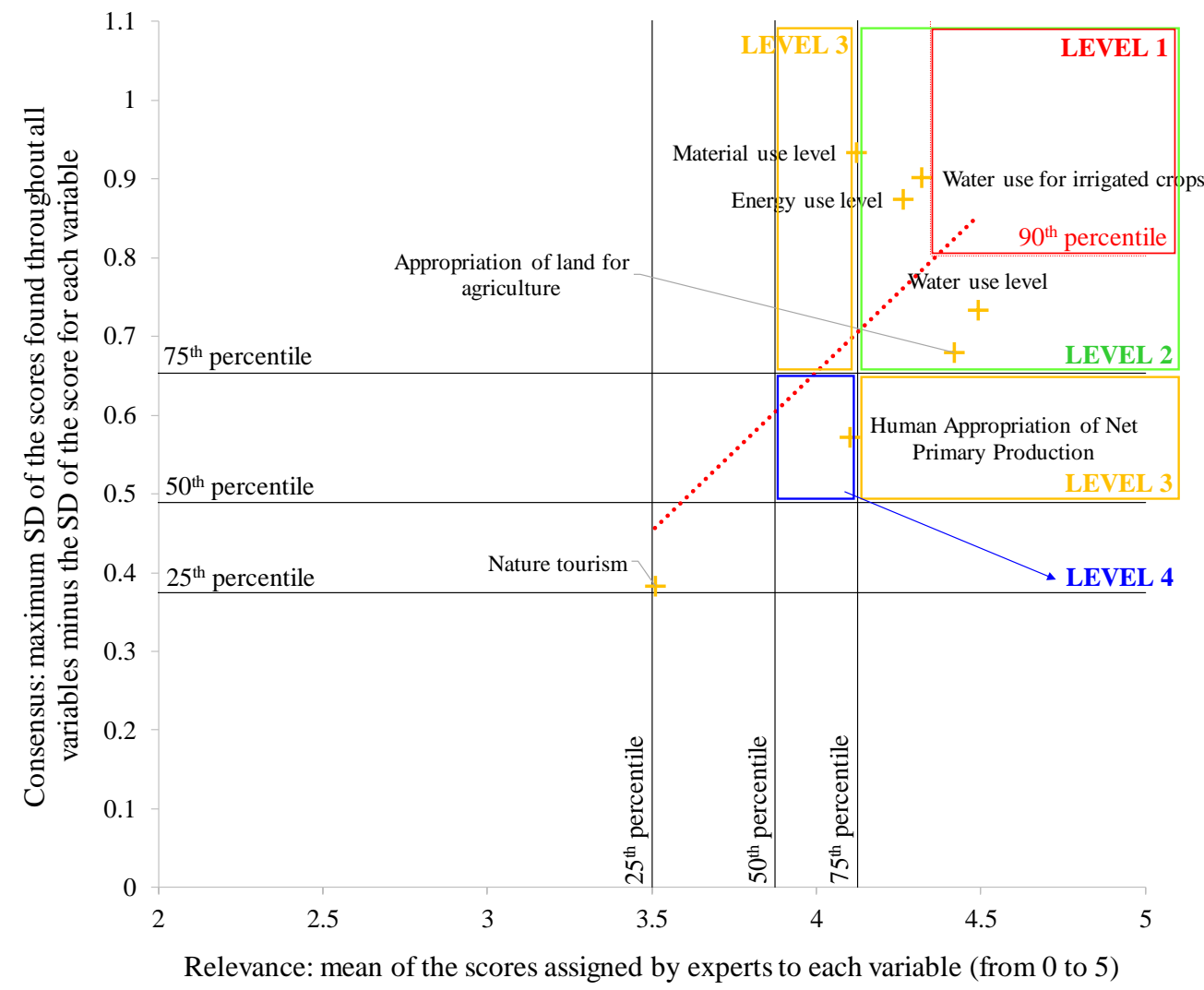

.... Regression line $y=-0.96+0.40 x$ $\mathrm{p}$-value $=0.107$ RMSE $=0.14$ $\mathrm{n}=7 ; \mathrm{r}=0.36$ $\mathrm{p}$-value $=0.444$

\section{Component:} interactions Dimension: ecosystem service demand 


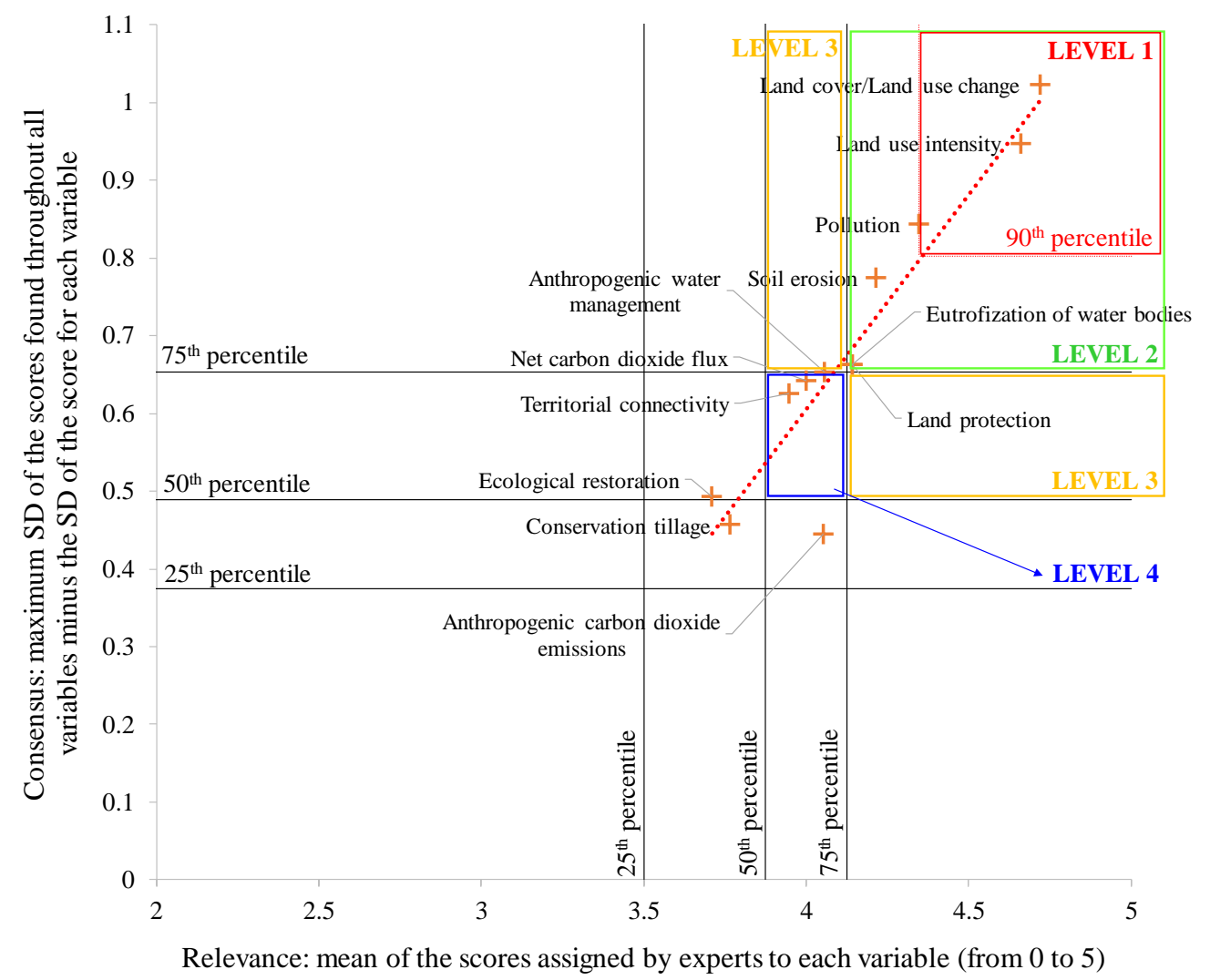

A6.13

Component:

Dimension: human

actions on the

environment
..... Regression line

$\mathrm{y}=-1.60+0.55 \mathrm{x}$

p-value $<0.001$

RMSE $=0.06$

$\mathrm{n}=12 ; \mathrm{r}=0.92$

p-value $<0.001$

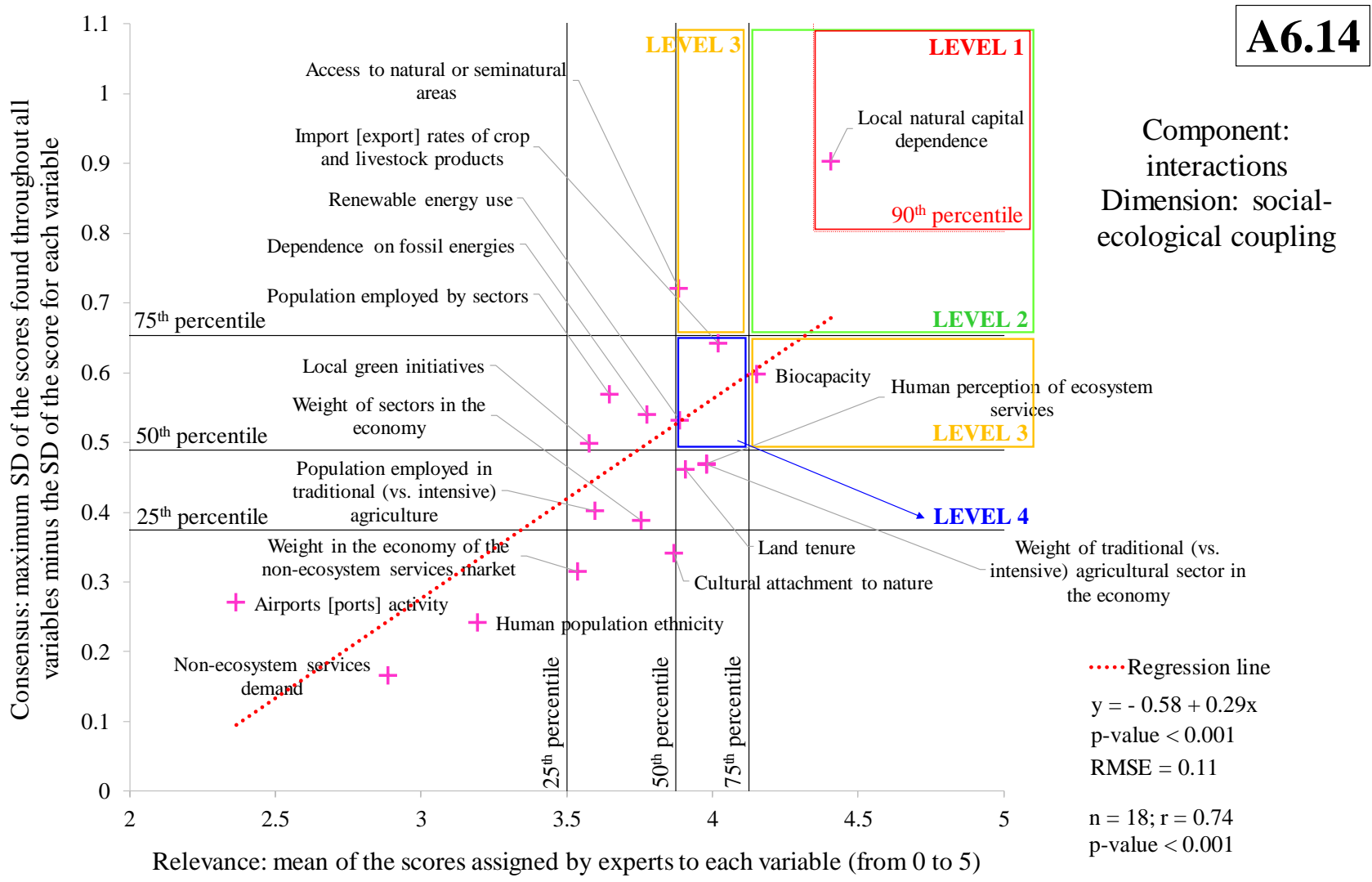




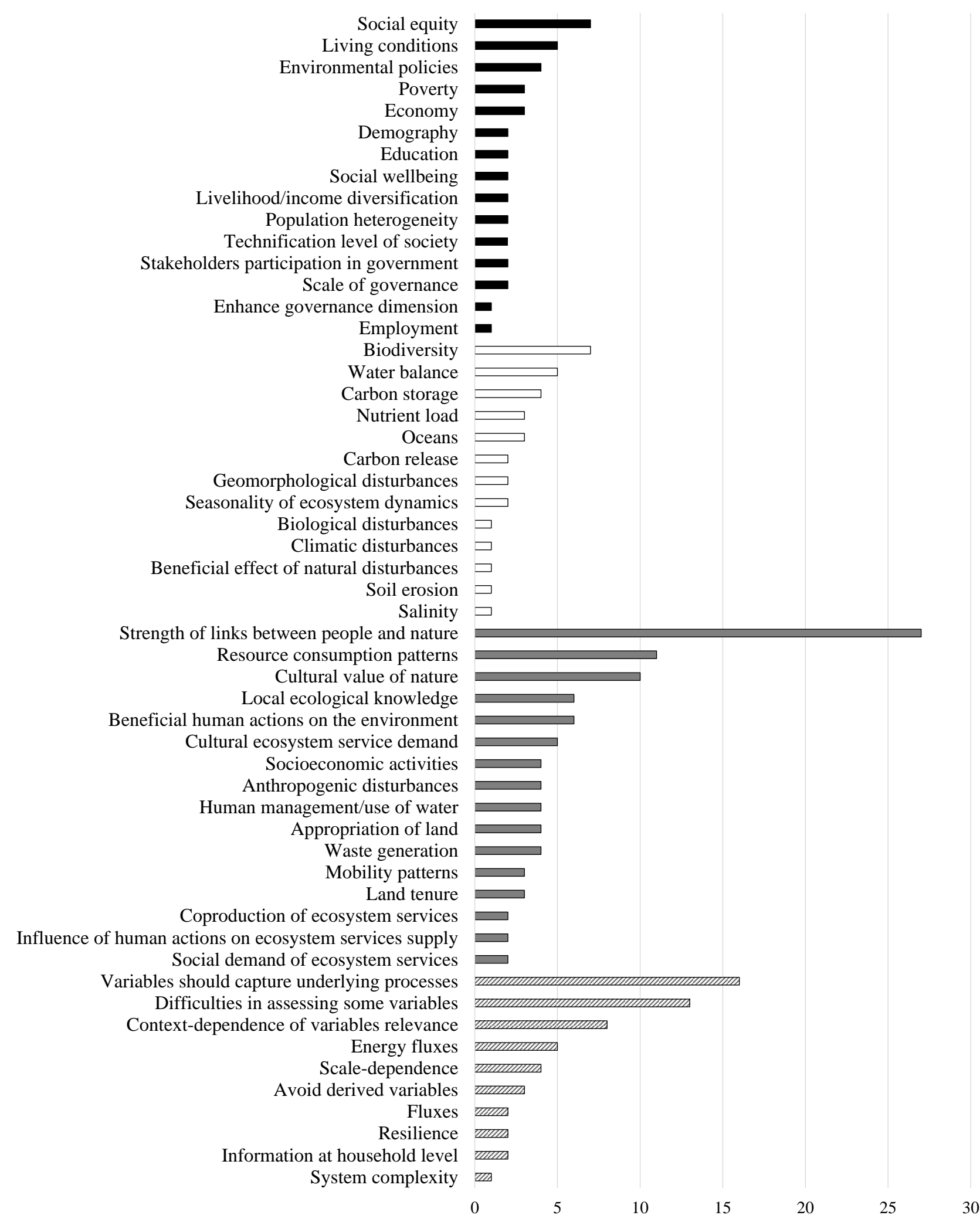

Number of times addressed by researchers in different dimensions

Figure A6.15. Extended version of Figure 4 in the manuscript. Featured topics addressed by respondents related to potential biases and gaps in the list of variables identified from comments and suggestions in the final survey. Black, white and gray bars represent the social system, ecological system and interaction components, respectively, while stripped bars reflect issues that are transversal to the whole conceptual framework. (See also these topics in the conceptual map of Appendix 7). 
Appendix 7. Conceptual map with keywords annotated from comments and suggestions

provided by respondents in both surveys

(zoom in to see in detail). The concepts are

shown hierarchically interlinked, and

structured into dimensions across the three

components of a social-ecological system

(social system, ecological system and

interactions between them). We used this

conceptual map to improve the preliminary list

of variables and dimensions after the

preliminary survey, and to assess the potential

biases and gaps in the improved list of

variables after the final survey.

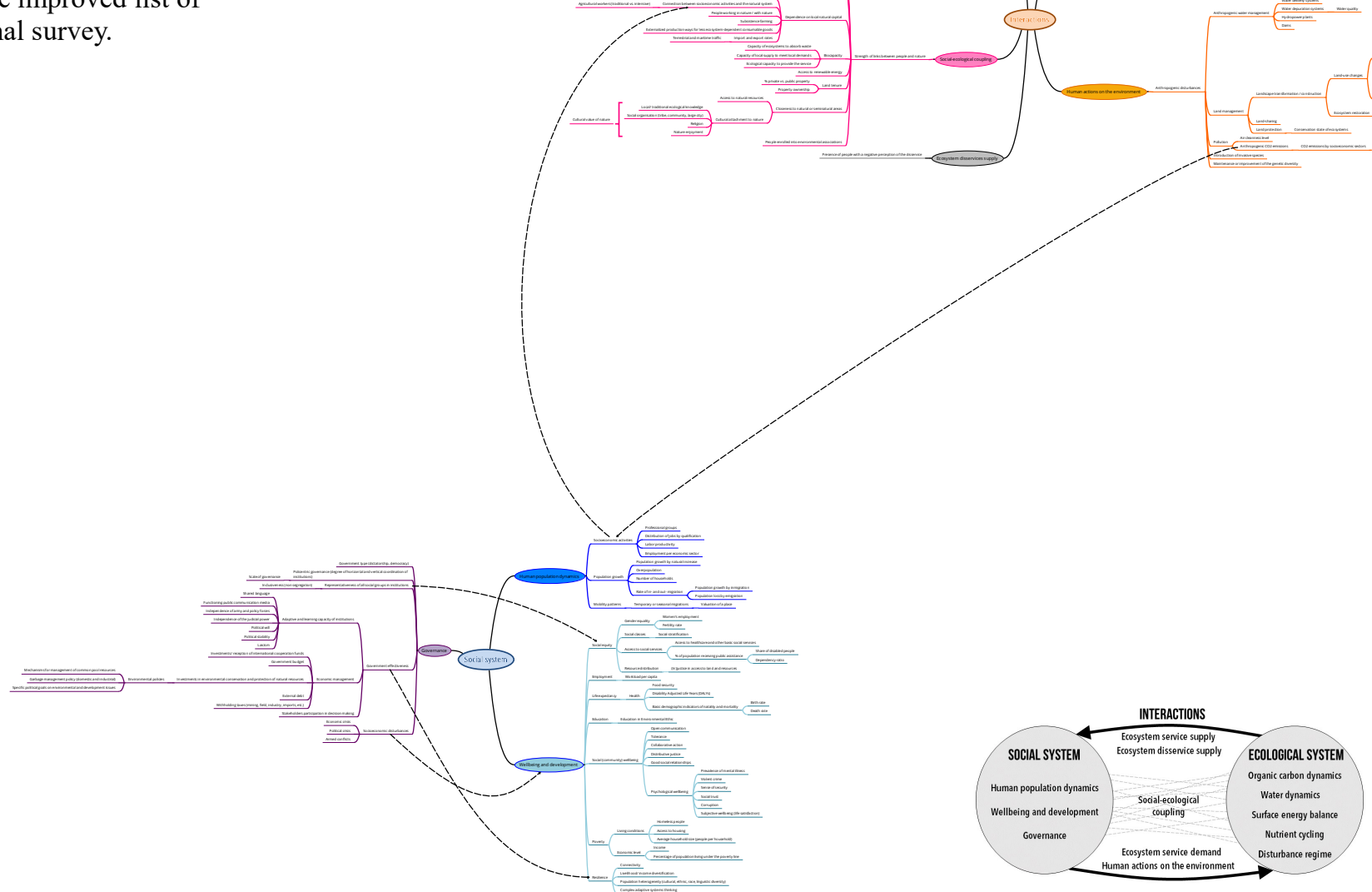


Appendix 8. Survey results.

Please click here to download file 'appendix8.xlsx'. 
Appendix 9. Acknowledgement to survey respondents.

We gratefully acknowledge the participation in the preliminary survey to:

\begin{tabular}{|c|c|c|c|}
\hline Last name & First name & "Institution/Department & Area of expertise \\
\hline Açma & Bülent & $\begin{array}{l}\text { Anadolu University - } \\
\text { Department of Economy } \\
\text { (Turkey) }\end{array}$ & $\begin{array}{l}\text { Social sciences } \\
\text { Sustainability Science } \\
\text { Environmental management / Territorial } \\
\text { planning }\end{array}$ \\
\hline Balvanera & Patricia & $\begin{array}{l}\text { Universidad Nacional } \\
\text { Autónoma de México - } \\
\text { Instituto de Investigaciones } \\
\text { en Ecosistemas y } \\
\text { Sustentabilidad (Mexico) }\end{array}$ & $\begin{array}{l}\text { Biophysical sciences } \\
\text { Sustainability Science } \\
\text { Environmental management / Territorial } \\
\text { planning } \\
\text { Biodiversity Science } \\
\text { Ecosystem services } \\
\text { Social-ecological systems }\end{array}$ \\
\hline $\begin{array}{l}\text { Bentley- } \\
\text { Brymer }\end{array}$ & Amanda & $\begin{array}{l}\text { University of Idaho - } \\
\text { Rangeland Center (USA) }\end{array}$ & $\begin{array}{l}\text { Social sciences } \\
\text { Environmental management / Territorial } \\
\text { planning }\end{array}$ \\
\hline Brown & Dan & $\begin{array}{l}\text { University of Michigan - } \\
\text { Graham Sustainability } \\
\text { Institute (USA) }\end{array}$ & $\begin{array}{l}\text { Sustainability Science } \\
\text { Environmental management / Territorial } \\
\text { planning } \\
\text { Remote sensing }\end{array}$ \\
\hline Chapin & Terry & $\begin{array}{l}\text { University of Alaska } \\
\text { Fairbanks - Institute of Arctic } \\
\text { Biology (USA) }\end{array}$ & Sustainability Science \\
\hline Ellis & Erle & $\begin{array}{l}\text { University of Maryland } \\
\text { Baltimore County - } \\
\text { Geography \& Environmental } \\
\text { Systems (USA) }\end{array}$ & $\begin{array}{l}\text { Biophysical sciences } \\
\text { Sustainability Science } \\
\text { Environmental management / Territorial } \\
\text { planning } \\
\text { Remote sensing } \\
\text { Biodiversity Science }\end{array}$ \\
\hline $\begin{array}{l}\text { Escribano- } \\
\text { Velasco }\end{array}$ & Paula & $\begin{array}{l}\text { Andalusian Center for the } \\
\text { Assessment and Monitoring } \\
\text { of Global Change - } \\
\text { University of Almería } \\
\text { (Spain) }\end{array}$ & $\begin{array}{l}\text { Environmental management / Territorial } \\
\text { planning Remote sensing }\end{array}$ \\
\hline Fabricius & Christo & $\begin{array}{l}\text { Nelson Mandela University - } \\
\text { Sustainability Research Unit } \\
\text { (South Africa) }\end{array}$ & Sustainability Science \\
\hline
\end{tabular}




\begin{tabular}{|c|c|c|c|}
\hline $\begin{array}{l}\text { García- } \\
\text { Nieto }\end{array}$ & Ana Paula & $\begin{array}{l}\text { Mediterranean Institute of } \\
\text { marine and terrestrial } \\
\text { Biodiversity and Ecology } \\
\text { (France) }\end{array}$ & Ecology \\
\hline $\begin{array}{l}\text { Garcia- } \\
\text { Valdecasas }\end{array}$ & $\begin{array}{l}\text { José } \\
\text { Ignacio }\end{array}$ & $\begin{array}{l}\text { University Carlos III de } \\
\text { Madrid - Department of } \\
\text { Social Sciences (Spain) }\end{array}$ & Social sciences \\
\hline Gibout & Christophe & $\begin{array}{l}\text { Université du Littoral Côte } \\
\text { d'Opale (France) }\end{array}$ & Social sciences \\
\hline Golland & Ami & $\begin{array}{l}\text { Stockholm University - } \\
\text { Stockholm Resilience Centre } \\
\text { (Sweden) }\end{array}$ & $\begin{array}{l}\text { Sustainability Science } \\
\text { Electronic engineering }\end{array}$ \\
\hline $\begin{array}{l}\text { Hernandez- } \\
\text { Zamorano }\end{array}$ & $\begin{array}{l}\text { Isaac } \\
\text { Rhodart }\end{array}$ & $\begin{array}{l}\text { Universidad Nacional } \\
\text { Autónoma de México - } \\
\text { National School of Higher } \\
\text { Studies Morelia (Mexico) }\end{array}$ & Enviromental Science \\
\hline Hevia & $\begin{array}{l}\text { Glenda } \\
\text { Denise }\end{array}$ & $\begin{array}{l}\text { Centre for Studies on Marine } \\
\text { Systems, CESIMAR - CCT } \\
\text { CENPAT- CONICET } \\
\text { (Argentina) }\end{array}$ & $\begin{array}{l}\text { Environmental management / Territorial } \\
\text { planning Biodiversity Science } \\
\text { Avian breeding biology }\end{array}$ \\
\hline Hinton & Jennifer & $\begin{array}{l}\text { Stockholm University - } \\
\text { Stockholm Resilience Centre } \\
\text { (Sweden) }\end{array}$ & $\begin{array}{l}\text { Social sciences } \\
\text { Sustainability Science }\end{array}$ \\
\hline Ignatov & Alex & $\begin{array}{l}\text { Russian University of } \\
\text { People's Friendship - R\&D } \\
\text { Center PhytoEngineering } \\
\text { LLC (Russia) }\end{array}$ & $\begin{array}{l}\text { Sustainability Science } \\
\text { Biodiversity Science }\end{array}$ \\
\hline Leitão & Pedro J. & $\begin{array}{l}\text { Technische Universität } \\
\text { Braunschweig - Department } \\
\text { of Landscape Ecology and } \\
\text { Environmental Systems } \\
\text { Analysis (Germany) }\end{array}$ & $\begin{array}{l}\text { Remote sensing } \\
\text { Biodiversity Science }\end{array}$ \\
\hline Locatelli & Bruno & $\begin{array}{l}\text { University of Montpellier - } \\
\text { Forests and Societies } \\
\text { research unit - CIRAD } \\
\text { (France) }\end{array}$ & Sustainability Science \\
\hline Martin & Romina & $\begin{array}{l}\text { Stockholm University - } \\
\text { Stockholm Resilience Centre } \\
\text { (Sweden) }\end{array}$ & Sustainability Science \\
\hline $\begin{array}{l}\text { Martinez- } \\
\text { Harms }\end{array}$ & Maria Jose & $\begin{array}{l}\text { Pontifical Catholic } \\
\text { University of Chile - } \\
\text { Department of Ecology } \\
\text { (Chile) }\end{array}$ & $\begin{array}{l}\text { Sustainability Science } \\
\text { Environmental management / Territorial } \\
\text { planning Biodiversity Science }\end{array}$ \\
\hline
\end{tabular}




\begin{tabular}{|c|c|c|c|}
\hline $\begin{array}{l}\text { Martin- } \\
\text { Lopez }\end{array}$ & Berta & $\begin{array}{l}\text { Leuphana University of } \\
\text { Luneburg - Institute for } \\
\text { Ethics and Transdisciplinary } \\
\text { Sustainability Research } \\
\text { (Germany) }\end{array}$ & Sustainability Science \\
\hline Nagendra & Harini & $\begin{array}{l}\text { Azim Premji University - } \\
\text { School of Development } \\
\text { (India) }\end{array}$ & $\begin{array}{l}\text { Sustainability Science } \\
\text { Remote sensing } \\
\text { Biodiversity Science }\end{array}$ \\
\hline Narducci & Jenna & $\begin{array}{l}\text { Boise State University - } \\
\text { Department of Geosciences } \\
\text { (USA) }\end{array}$ & $\begin{array}{l}\text { Environmental management / Territorial } \\
\text { planning }\end{array}$ \\
\hline Niquil & Nathalie & $\begin{array}{l}\text { French National Centre for } \\
\text { Scientific Research - Institut } \\
\text { écologie et environnement } \\
\text { (France) }\end{array}$ & $\begin{array}{l}\text { Biodiversity Science } \\
\text { Ecology }\end{array}$ \\
\hline Noss & Reed & $\begin{array}{l}\text { Florida Institute for } \\
\text { Conservation Science (USA) }\end{array}$ & $\begin{array}{l}\text { Environmental management / Territorial } \\
\text { planning, Biodiversity Science }\end{array}$ \\
\hline Pandey & Rajiv & $\begin{array}{l}\text { Indian Council of Forestry } \\
\text { Research \&Education (India) }\end{array}$ & $\begin{array}{l}\text { Vulnerability and Adaptation in Social- } \\
\text { ecological systems }\end{array}$ \\
\hline Pardo & Mercedes & $\begin{array}{l}\text { University Carlos III de } \\
\text { Madrid - Sociology of } \\
\text { Climate Change and } \\
\text { Sustainable Development } \\
\text { (Spain) }\end{array}$ & Social sciences \\
\hline Rodríguez & Jon Paul & $\begin{array}{l}\text { Instituto Venezolano de } \\
\text { Investigaciones Científicas - } \\
\text { Centro de Ecología } \\
\text { (Venezuela) }\end{array}$ & Biodiversity Science \\
\hline $\begin{array}{l}\text { Romero- } \\
\text { Calcerrada }\end{array}$ & Raúl & $\begin{array}{l}\text { King Juan Carlos University } \\
\text { - Faculty of Legal and Social } \\
\text { Sciences (Spain) }\end{array}$ & $\begin{array}{l}\text { Environmental management / Territorial } \\
\text { planning Remote sensing }\end{array}$ \\
\hline Ruggeri & Daniela & $\begin{array}{l}\text { University of Cagliari - } \\
\text { Dipartimento di Ingegneria } \\
\text { Civile, Ambientale e } \\
\text { Architettura (Italy) }\end{array}$ & $\begin{array}{l}\text { Environmental management / Territorial } \\
\text { planning }\end{array}$ \\
\hline Vallet & Améline & $\begin{array}{l}\text { AgroParisTech - CIRED } \\
\text { (France) }\end{array}$ & $\begin{array}{l}\text { Biophysical sciences } \\
\text { Social sciences }\end{array}$ \\
\hline
\end{tabular}

... and to 25 additional researchers who anonymously filled the preliminary survey 
We also gratefully acknowledge the participation in the final survey to:

\begin{tabular}{|c|c|c|c|}
\hline Last name & First name & IInstitution/Department & Area of expertise \\
\hline Baró & Francesc & $\begin{array}{l}\text { Autonomous University of } \\
\text { Barcelona - Institute of } \\
\text { Environmental Sciences and } \\
\text { Technologies (Spain) }\end{array}$ & $\begin{array}{l}\text { Sustainability Science } \\
\text { Environmental management / Territorial } \\
\text { planning }\end{array}$ \\
\hline Berbery & E. Hugo & $\begin{array}{l}\text { University of Maryland - } \\
\text { Earth System Science } \\
\text { Interdisciplinary Center } \\
\text { (USA) }\end{array}$ & Climate Sciences \\
\hline Blenckner & Thorsten & $\begin{array}{l}\text { Stockholm University - } \\
\text { Stockholm Resilience } \\
\text { Centre (Sweden) }\end{array}$ & $\begin{array}{l}\text { Biophysical sciences } \\
\text { Sustainability Science } \\
\text { Biodiversity Science }\end{array}$ \\
\hline Blum & Alfredo & $\begin{array}{l}\text { Ministerio de Vivienda, } \\
\text { Ordenamiento Territorial y } \\
\text { Medio Ambiente (Uruguay) }\end{array}$ & $\begin{array}{l}\text { Social sciences } \\
\text { Sustainability Science } \\
\text { Environmental management / Territorial } \\
\text { planning }\end{array}$ \\
\hline Castro & Antonio J. & $\begin{array}{l}\text { University of Almería - } \\
\text { Department of Biology and } \\
\text { Geology (Spain) }\end{array}$ & $\begin{array}{l}\text { Biophysical sciences } \\
\text { Social sciences } \\
\text { Sustainability Science }\end{array}$ \\
\hline Ceausu & Silvia & $\begin{array}{l}\text { Aarhus University - } \\
\text { Department of Bioscience } \\
\text { (Denmark) }\end{array}$ & $\begin{array}{l}\text { Environmental management / Territorial } \\
\text { planning } \\
\text { Biodiversity Science }\end{array}$ \\
\hline Couvet & Denis & $\begin{array}{l}\text { Muséum National d'Histoire } \\
\text { Naturelle (France) }\end{array}$ & Biodiversity Science \\
\hline Felipe-Lucia & María & $\begin{array}{l}\text { Helmholtz Centre for } \\
\text { Environmental Research - } \\
\text { Centre for Integrative } \\
\text { Biodiversity Research } \\
\text { (iDiv) (Germany) }\end{array}$ & $\begin{array}{l}\text { Biophysical sciences } \\
\text { Social sciences } \\
\text { Sustainability Science } \\
\text { Environmental management / Territorial } \\
\text { planning Biodiversity Science } \\
\text { Ecosystem services }\end{array}$ \\
\hline Filatova & Tatiana & $\begin{array}{l}\text { University of Twente - } \\
\text { Department of Governance } \\
\text { and Technology for } \\
\text { Sustainable Development } \\
\text { (The Netherlands) }\end{array}$ & $\begin{array}{l}\text { Social sciences } \\
\text { Sustainability Science } \\
\text { Environmental management / Territorial } \\
\text { planning }\end{array}$ \\
\hline $\begin{array}{l}\text { Fischer- } \\
\text { Kowalski }\end{array}$ & Marina & $\begin{array}{l}\text { University of Natural } \\
\text { Resources and Life } \\
\text { Sciences Vienna - Institute } \\
\text { of Social Ecology (Austria) }\end{array}$ & $\begin{array}{l}\text { Social sciences } \\
\text { Sustainability Science }\end{array}$ \\
\hline Furman & Eeva & $\begin{array}{l}\text { Finnish Environment } \\
\text { Institute | ymparisto - } \\
\text { Centre for Environmental } \\
\text { Policy (Finland) }\end{array}$ & $\begin{array}{l}\text { Social sciences } \\
\text { Sustainability Science } \\
\text { Environmental management / Territorial } \\
\text { planning } \\
\text { Biodiversity Science }\end{array}$ \\
\hline
\end{tabular}




\begin{tabular}{|c|c|c|c|}
\hline $\begin{array}{l}\text { Garcia del } \\
\text { Amo }\end{array}$ & David & $\begin{array}{l}\text { Autonomous University of } \\
\text { Barcelona - Institute of } \\
\text { Environmental Sciences and } \\
\text { Technologies (Spain) }\end{array}$ & Sustainability Science \\
\hline Geijzendorffer & Ilse & $\begin{array}{l}\text { Tour du Valat - Research } \\
\text { Institute for the } \\
\text { conservation of } \\
\text { Mediterranean Wetlands } \\
\text { (France) }\end{array}$ & $\begin{array}{l}\text { Biophysical sciences } \\
\text { Sustainability Science } \\
\text { Environmental management / Territorial } \\
\text { planning Biodiversity Science } \\
\text { Ecosystem services }\end{array}$ \\
\hline $\begin{array}{l}\text { Ifejika } \\
\text { Speranza }\end{array}$ & Chinwe & $\begin{array}{l}\text { Universität Bern - Centre } \\
\text { for Development and } \\
\text { Environment - Institute of } \\
\text { Geography (Switzerland) }\end{array}$ & Sustainability Science \\
\hline $\begin{array}{l}\text { López- } \\
\text { Rodríguez }\end{array}$ & María D. & $\begin{array}{l}\text { University of Almeria - } \\
\text { Andalusian Center for the } \\
\text { Assessment and Monitoring } \\
\text { of Global Change (Spain) }\end{array}$ & Sustainability Science \\
\hline Luque & Sandra & $\begin{array}{l}\text { National Research Institute } \\
\text { of Science and Technology } \\
\text { for Environment and } \\
\text { Agriculture - UMR TETIS } \\
\text { Territoires, Environnement, } \\
\text { Télédétection et Information } \\
\text { Spatiale (France) }\end{array}$ & $\begin{array}{l}\text { Biophysical sciences } \\
\text { Sustainability Science } \\
\text { Environmental management / Territorial } \\
\text { planning Remote sensing } \\
\text { Biodiversity Science }\end{array}$ \\
\hline Macchi & Leandro & $\begin{array}{l}\text { CONICET - Instituto de } \\
\text { Ecología Regional (IER) - } \\
\text { Universidad Nacional de } \\
\text { Tucumán (Argentina) }\end{array}$ & $\begin{array}{l}\text { Sustainability Science } \\
\text { Biodiversity Science }\end{array}$ \\
\hline Mahecha & Miguel & $\begin{array}{l}\text { Max Planck Institute for } \\
\text { Biogeochemistry - } \\
\text { Department of } \\
\text { Biogeochemical Integration } \\
\text { (Germany) }\end{array}$ & $\begin{array}{l}\text { Biophysical sciences } \\
\text { Sustainability Science } \\
\text { Remote sensing } \\
\text { Biodiversity Science }\end{array}$ \\
\hline $\begin{array}{l}\text { Martinez- } \\
\text { Harms }\end{array}$ & Maria Jose & $\begin{array}{l}\text { Pontifical Catholic } \\
\text { University of Chile - } \\
\text { Department of Ecology } \\
\text { (Chile) }\end{array}$ & $\begin{array}{l}\text { Sustainability Science } \\
\text { Environmental management / Territorial } \\
\text { planning } \\
\text { Biodiversity Science }\end{array}$ \\
\hline $\begin{array}{l}\text { Munday } \\
\text { Seguel }\end{array}$ & Daniel & $\begin{array}{l}\text { Economic Commission for } \\
\text { Latin America and the } \\
\text { Caribbean (Chile) }\end{array}$ & $\begin{array}{l}\text { Environmental management / Territorial } \\
\text { planning }\end{array}$ \\
\hline Onaindia & Miren & $\begin{array}{l}\text { University of the Basque } \\
\text { Country - Department of } \\
\text { Plant Biology and Ecology } \\
\text { (Spain) }\end{array}$ & $\begin{array}{l}\text { Biophysical sciences } \\
\text { Environmental management / Territorial } \\
\text { planning } \\
\text { Biodiversity Science }\end{array}$ \\
\hline
\end{tabular}




\begin{tabular}{|c|c|c|c|}
\hline Ozán & Ivana & $\begin{array}{l}\text { CONICET - Instituto de } \\
\text { Geociencias Básicas, } \\
\text { Ambientales y Aplicadas de } \\
\text { Buenos Aires (Argentina) }\end{array}$ & $\begin{array}{l}\text { Social sciences } \\
\text { Geoarchaeology }\end{array}$ \\
\hline Piñeiro & Gervasio & $\begin{array}{l}\text { Universidad de Buenos } \\
\text { Aires - Facultad de } \\
\text { Agronomía (Argentina) }\end{array}$ & $\begin{array}{l}\text { Biophysical sciences } \\
\text { Remote sensing }\end{array}$ \\
\hline Requena & $\begin{array}{l}\text { Juan } \\
\text { Miguel }\end{array}$ & $\begin{array}{l}\text { Boise State University - } \\
\text { Department of Biological } \\
\text { Sciences (USA) }\end{array}$ & $\begin{array}{l}\text { Remote sensing } \\
\text { Biodiversity Science }\end{array}$ \\
\hline Roche & Philip & $\begin{array}{l}\text { National Research Institute } \\
\text { of Science and Technology } \\
\text { for Environment and } \\
\text { Agriculture IRSTEA - } \\
\text { Lands Department (France) }\end{array}$ & $\begin{array}{l}\text { Remote sensing } \\
\text { Biodiversity Science }\end{array}$ \\
\hline $\begin{array}{l}\text { Rosales } \\
\text { Benites de } \\
\text { Franco }\end{array}$ & Marina & $\begin{array}{l}\text { Federico Villarreal National } \\
\text { University - Biological } \\
\text { Sciences (Peru) }\end{array}$ & Biodiversity Science \\
\hline Saldivar & Americo & $\begin{array}{l}\text { Universidad Nacional } \\
\text { Autónoma de México - } \\
\text { Faculty of Economy } \\
\text { (Mexico) }\end{array}$ & \\
\hline Volk & Martin & $\begin{array}{l}\text { UFZ-Helmholtz Centre for } \\
\text { Environmental Research - } \\
\text { Department of } \\
\text { Computational Landscape } \\
\text { Ecology (Germany) }\end{array}$ & $\begin{array}{l}\text { Biophysical sciences } \\
\text { Sustainability Science } \\
\text { Environmental management / Territorial } \\
\text { planning } \\
\text { Biodiversity Science }\end{array}$ \\
\hline Watmough & Gary & $\begin{array}{l}\text { The University of } \\
\text { Edinburgh - School of } \\
\text { GeoSciences (UK) }\end{array}$ & $\begin{array}{l}\text { Sustainability Science } \\
\text { Remote sensing }\end{array}$ \\
\hline
\end{tabular}

$\ldots$ and to 30 additional researchers who anonymously filled the final survey 